Ricardo Lacerda Baitelo

\title{
Modelagem Completa e Análise dos Recursos Energéticos do Lado da Demanda para o PIR
}

Dissertação para a obtenção de título de Mestre em Engenharia Elétrica

da Escola Politécnica da

Universidade de São Paulo 
Ricardo Lacerda Baitelo

\section{Modelagem Completa e Análise dos Recursos Energéticos do Lado da Demanda para o PIR}

Dissertação para a obtenção de título de Mestre em Engenharia Elétrica

da Escola Politécnica da

Universidade de São Paulo

Área de Concentração:

Sistemas de Potência

Orientador:

Prof. Dr. Miguel Edgar Morales Udaeta 
FICHA CATALOGRÁFICA

\section{Baitelo, Ricardo Lacerda}

Modelagem completa e análise dos recursos energéticos do lado da demanda para o PIR I R.L. Baitelo. -- ed.rev. -- São Paulo, 2006.

p.

Dissertação (Mestrado) - Escola Politécnica da Universidade de São Paulo. Departamento de Engenharia de Energia e Automação Elétricas.

1.Conservação de energia 2.Demanda (Gerenciamento) 3.Recursos energéticos I.Universidade de São Paulo. Escola Politécnica. Departamento de Engenharia de Energia e Automação Elétricas II.t. 


\section{Agradecimentos}

Ao Professor e Orientador Miguel Udaeta, pela orientação e esclarecimento, tanto em momentos plácidos como em dilemas cruciais, ao longo do percurso.

Ao Professor Cláudio Luiz Ribeiro Galvão por todo o apoio concedido, tanto aos projetos de pesquisa quanto à realização deste trabalho.

Aos Professores José Aquiles Baesso Grimoni e André Luiz Veiga Gimenes, pelas valiosas recomendações sobre a condução e o prosseguimento desta dissertação, durante o processo de qualificação, e pelos vários favores concedidos durante a execução da mesma.

Ao Departamento de Energia e Automação Elétrica, por todo o respaldo tecnológico e o apoio financeiro, sem os quais a execução e a materialização desta dissertação jamais teriam sido possíveis.

A Ricardo Fujii pelo compartilhamento de idéias, novas ou antigas, e pelo debate cotidiano que fomentou grande parte destas linhas escritas.

A Mário Biague e a todo o grupo SEEDS pelas contribuições, ponderações e questionamentos de grande valia tanto no processo como na conclusão deste trabalho.

A Carlos Farias e todos da Cooperhidro, em Araçatuba, pela recepção em diversas oportunidades e por concretizarem a pesquisa e o estudo dos recursos energéticos na região.

A todos os parentes, amigos e familiares que me acompanharam proximamente ou à distância durante todo este período, leigos ou não em PIR.

E em especial à minha esposa Mônica, que suportou elegantemente o humor volátil do autor em épocas de redações intensivas e noites pouco dormidas. 


\section{Índice}

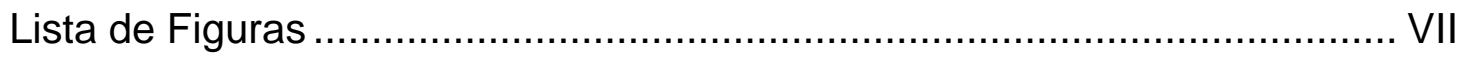

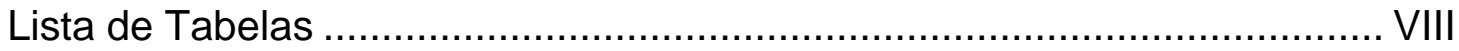

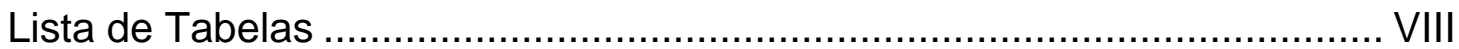

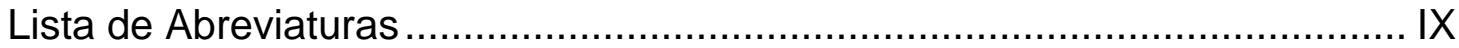

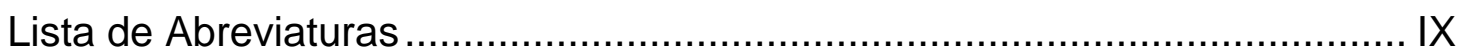

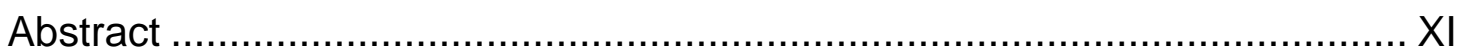

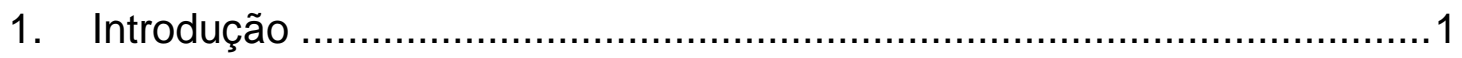

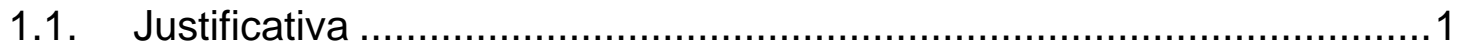

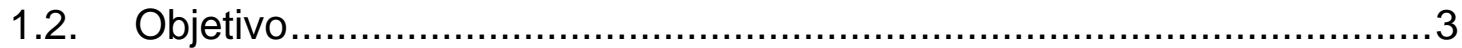

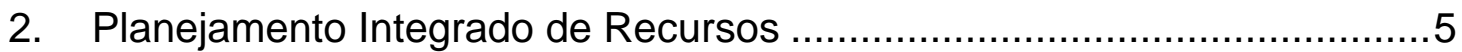

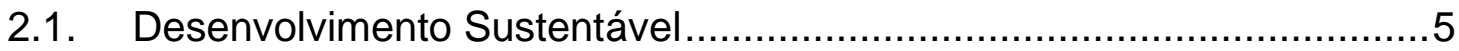

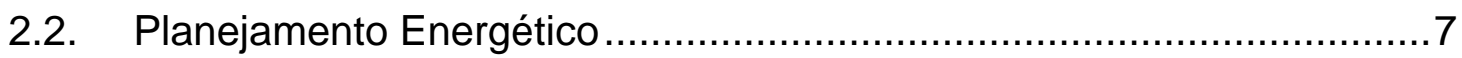

2.3. Características do Planejamento Integrado de Recursos ..........................

2.4. Introdução ao Modelo de Caracterização de Recursos de Demanda..13

3. Modelo de Caracterização e Análise de Recursos de Demanda ............17

3.1. Gerenciamento pelo Lado da Demanda ........................................17

3.2. Etapas do Modelo de Caracterização e Análise de RELD........................27

4. Recursos Energéticos do Lado da Demanda .......................................30

4.1. Formalização de Recursos Energéticos do Lado da Demanda ................30

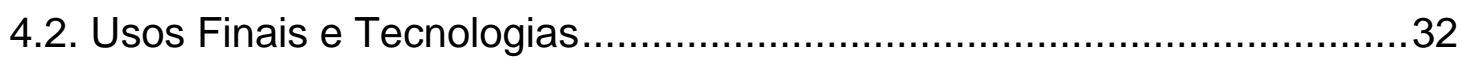

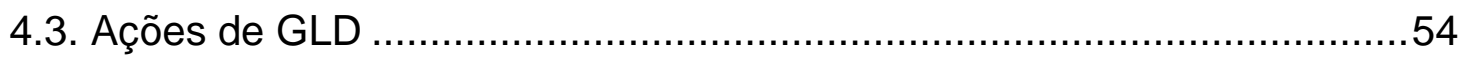

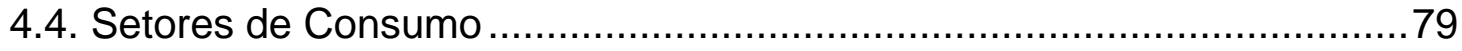

5. Dimensões de Análise e Respectivos Atributos ...................................87

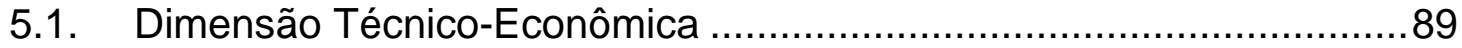

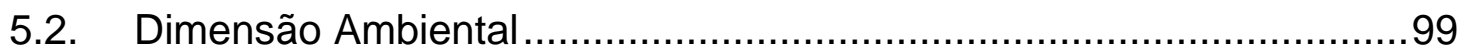

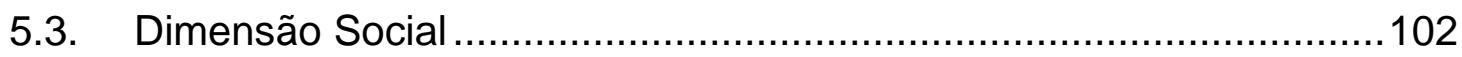

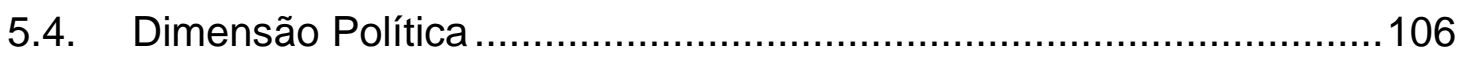

6. Potencial Energético de Recursos Energéticos do Lado da Demanda .117

6.1. Definições e Considerações sobre Potenciais Energéticos ................... 117

6.2. Restrições aos Potenciais Energéticos.............................................119 
6.3. Potenciais Energéticos e Custo da Energia Economizada de Recursos do Lado da Demanda ............................................................................ 121

7. Aplicação Real do Modelo em Estudo de Caso em Araçatuba ..............131

7.1. Região Administrativa de Araçatuba.............................................. 133

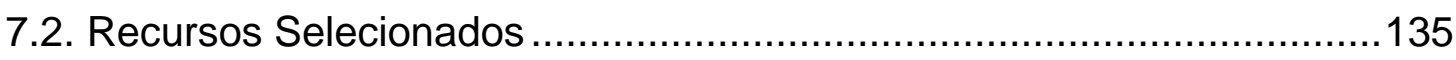

7.3. Avaliação dos Custos Completos ................................................... 136

7.4. Cálculo dos Potenciais Energéticos............................................... 140

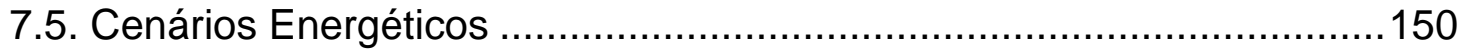

7.6. Considerações sobre os resultados do Estudo de Caso .......................157

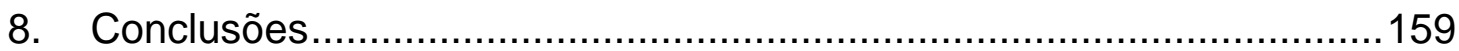

Anexo: Tabelas da Avaliação de Custos Completos .................................161

9. Referências Bibliográficas ........................................................ 175 


\section{Lista de Figuras}

Figura 2.3: Diagrama do Planejamento Integrado de Recursos ...............11

Figura 2.4: Diagrama da Modelagem Completa e Análise dos RELD.........16

Figura 3.1.2.1: Redução de Pico ..................................................... 18

Figura 3.1.2.2: Conservação estratégica ............................................19

Figura 3.1.2.3: Preenchimento de Vales .............................................19

Figura 3.1.2.4: Crescimento Estratégico ..........................................20

Figura 3.1.2.5: Deslocamento da Carga ......................................... 20

Figura 3.1.2.6: Curva de Carga Flexível ..........................................21

Figura 4.3.6.3: Curvas de Carga para Armazenagem Parcial e Total.........78

Figura 4.4.1: Setorização do Consumo de Eletricidade...........................80

Figura 4.4.2. Consumo de Eletricidade por Setores.............................83

Figura 4.4.3. Consumo Final de Energia por Setores .......................... 84

Figura 7.1: Região Administrativa de Araçatuba................................ 133

Figura 7.3. Classificação Final ACC -2035 ...................................... 139

Figura 7.5.1.a: Cenário Referencial -Eletricidade (2000-2035) ............... 152

Figura 7.5.1.b: Cenário Referencial -Energia (2000-2035)..................... 153

Figura 7.5.2.a: Cenário de Consumo Realizável - Eletricidade (2000-2035)

Figura 7.5.2.b: Cenário de Consumo Realizável - Energia (2000-2035)...155

Figura 7.5.3.a: Cenário de Eficiência Maximizada - Eletricidade (2000-2035)

Figura 7.5.3.b: Cenário de Eficiência Maximizada - Energia (2000-2035) 157 


\section{Lista de Tabelas}

Tabela 4.2.1.2: Tipos de Lâmpadas e Eficiências Associadas ......................36

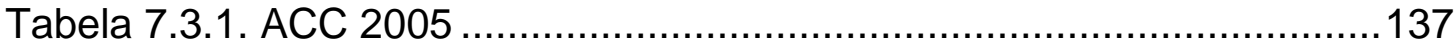

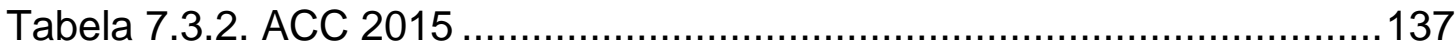

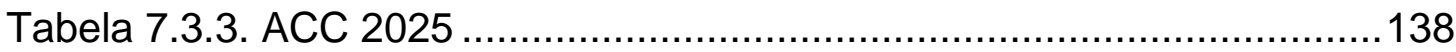

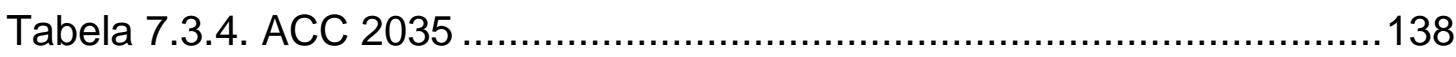

Tabela 7.4.10: Potenciais Energéticos e Custo da Energia Economizada ... 149

Tabela A 1: Dimensão Econômica - Correspondência de Avaliações ..........161

Tabela A 2: Dimensão Ambiental ........................................................ 161

Tabela A 3: Dimensão Social ........................................................... 162

Tabela A 4: Dimensão Política .............................................................. 162

Tabela A 5: Dimensão Econômica - Pontuações 2005.............................. 163

Tabela A 6: Dimensão Ambiental - Pontuações 2005 ................................ 164

Tabela A 7: Dimensão Social - Pontuações 2005..................................... 164

Tabela A 8: Dimensão Política - Pontuações 2005................................... 165

Tabela A 9: Dimensão Econômica - Pontuações 2015 ............................... 166

Tabela A 10: Dimensão Ambiental - Pontuações 2015..............................167

Tabela A 11: Dimensão Social - Pontuações 2015................................... 167

Tabela A 12: Dimensão Política - Pontuações 2015............................... 168

Tabela A 13: Dimensão Econômica - Pontuações 2025............................. 169

Tabela A 14: Dimensão Ambiental - Pontuações 2025..............................170

Tabela A 15: Dimensão Social - Pontuações 2025.................................. 170

Tabela A 16: Dimensão Política - Pontuações 2025................................ 171

Tabela A 17: Dimensão Econômica - Pontuações 2035.............................172

Tabela A 18: Dimensão Ambiental - Pontuações 2035.............................. 173

Tabela A 19: Dimensão Social - Pontuações 2035...................................173

Tabela A 20: Dimensão Política - Pontuações 2035.................................174 


\section{Lista de Abreviaturas}

ABNT - Associação Brasileira de Normas Técnicas

ACC - Avaliação dos Custos Completos

ACV - Análise de Ciclo de Vida

ANEEL - Agência Nacional de Energia Elétrica

BAU - Business as Usual

CONPET - Programa Nacional de Uso Racional de Derivados de Petróleo e de Gás Natural

Eletrobrás - Centrais Elétricas Brasileiras

En-In - Envolvidos e Interessados

GLD - Gerenciamento do Lado da Demanda

LEAP - Long-Range Energy Alternatives Planning System

RELD - Recursos Energéticos do Lado da Demanda

RELO - Recursos Energéticos do Lado da Oferta

PIR - Planejamento Integrado de Recursos

Petrobrás - Petróleo Brasileiro S/A

PROCEL - Programa Nacional de Conservação de Energia Elétrica

TIR - Taxa Interna de Retorno 


\section{Resumo}

Esta dissertação propõe um modelo de caracterização de recursos energéticos do lado da demanda que pretende abranger todos os tipos de ações e medidas referentes ao gerenciamento da demanda e à conservação energética, avaliando-as de forma holística, dentro de quatro dimensões: técnico-econômica, ambiental, social e política.

Os recursos considerados na composição do modelo são submetidos às fases de Inventário de Recursos Energéticos do Lado da Demanda, Caracterização das Dimensões e Atributos de Avaliação de Recursos, Formulação dos Potenciais Energéticos e Aplicação do Modelo em Caso Piloto.

O Inventário de Recursos Energéticos do Lado da Demanda pretende levantar, descrever e segmentar todas as alternativas energéticas de GLD e setores de consumo energético. A Caracterização da Avaliação de Recursos delimita as esferas de análise de recursos e a caracterização de seus atributos quanto a custos e benefícios provenientes de seu emprego. A Formulação dos Potenciais Energéticos define seu cálculo a partir de sua amplitude e restrições gerais de aplicação. O modelo é aplicado em um estudo piloto, na Região Administrativa de Araçatuba, por meio de um exercício de formulação do PIR, considerando a utilização de ferramentas de Avaliação dos Custos Completos, Cálculo de Potenciais Energéticos e Elaboração de Cenários de Projeção do Consumo Energético para um horizonte de tempo determinado. 


\section{Abstract}

This work presents a model for the characterization and assessment of demand side energy resources, which intends to comprehend every kind of action or measure related to demand side management and energy conservation, evaluated thouroughly into four dimensions: technical-economical, environmental, social and political. The resources included in the composition of the model are subjected to the stages of Inventary of Demand Side Resources, Characterization of Dimensions and Attributes of the Resources Assessment, Formulation of Energy Potentials and Model Application on a Real Case Study.

The Inventary of Demand Side Resources intends to enlist, describe and segment all demand side management energy alternatives and their application in different economy sectors. The Characterization of the Resources Assessment defines the spheres of the assessment of resources and the characterization of its attributes as for costs and benefits resulting from their utilization. The Formulation of Energy Potentials defines their accounting based on their range and general application restrictions. The Model is applied in a case study, in the Administrative Region of Araçatuba, through an exercise of IRP formulation, regarding the utilization of Full Cost Accounting, Energy Potentials Accounting and Scenarios of Energy Consumption for a determined horizon. 


\section{Introdução}

\subsection{Justificativa}

A energia é uma condição determinante para o estabelecimento do bem estar e da qualidade de vida da população mundial, para o atendimento de níveis mínimos de saúde, educação e conforto. É igualmente imprescindível à infra-estrutura da atividade econômica, na realização de atividades de transformação e de produção, desde o período industrial até a atual era da Informação. O aumento destas atividades e o desenvolvimento sócio-econômico têm feito a demanda humana por energia crescer a níveis que restringem a disponibilidade de recursos energéticos $[1,2]$

A obtenção de energia a partir destes recursos implica em diversos tipos de impactos negativos inevitáveis, ainda que em maior ou menor escala, de acordo com a fonte energética explorada. Estes impactos, muitas vezes considerados marginais sob uma perspectiva técnico-econômica de análise, não são integralmente abordados dentro do paradigma tradicional de planejamento energético.

O tratamento destes impactos no processo de planejamento energético, através da minimização de custos e maximização de benefícios de ordem geral (política, social, ambiental e sócio-econômica) deve ocorrer não apenas por meio da avaliação de recursos energéticos de oferta em termos de custos e impactos, mas também por metodologias que apontem a inclusão de alternativas do lado da demanda energética, representadas por medidas de gerenciamento de carga, eficiência energética e uso consciente e racional da energia nos diversos setores de consumo $[1,2]$.

Dentro deste perfil de planejamento energético voltado aos fundamentos do Desenvolvimento Sustentável, o PIR - Planejamento Integrado de Recursos, segue 
uma série de diretrizes, das quais as principais são: a inclusão de todas as opções de recursos energéticos no processo de planejamento; a caracterização de recursos dentro de diferentes dimensões de análise (perspectivas ambiental, social, política e técnico-econômica), buscando a minimização de impactos gerais negativos à sua implementação e utilização; a consideração, em grau equivalente de importância, de opções energéticas dos lados da demanda e oferta no planejamento energético e, por fim, a participação de todos os agentes do setor energético no processo de análise de recursos.

Desta forma, propõe-se, a partir dos atributos do PIR, um modelo para a análise completa e a caracterização de recursos energéticos do lado da demanda, com o objetivo geral de explicitar uma metodologia de levantamento, análise e mensuração de potencial energético destes recursos. Este modelo é geograficamente e temporalmente adaptável, e portanto passível de aplicação em âmbito regional ou nacional, para diferentes setores de consumo energético, em horizontes variáveis de tempo. 


\subsection{Objetivo}

O objetivo desta Dissertação de Mestrado é a elaboração de um Modelo de Caracterização de Recursos Energéticos de Demanda, que explicite uma metodologia de levantamento, caracterização e análise de todas as alternativas energéticas do lado da demanda. Tais alternativas abrangem ações, programas e políticas de Gerenciamento do Lado da Demanda, voltadas à conservação estratégica de energia, ao gerenciamento da curva de carga e à alteração do consumo energético em direção ao uso racional de energia e ao desenvolvimento sustentável. Os recursos considerados na composição do modelo são submetidos às seguintes fases:

- Inventário de Recursos Energéticos do Lado da Demanda: através do levantamento e descrição de todas as alternativas energéticas e sua segmentação em diferentes grupos de medidas e ações, usos finais e tecnologias associadas de GLD e setores de consumo energético;

- Caracterização das Quatro Dimensões de Avaliação de Recursos: delimitação das esferas técnico-econômica, ambiental, social e política de análise de recursos e a caracterização de seus atributos e sub-atributos (representando impactos inerentes à utilização e implantação de recursos), visando uma avaliação completa dos recursos do lado da demanda quanto a custos e benefícios provenientes de seu emprego;

- Formulação dos Potenciais Energéticos Teórico, Realizável e de Mercado: Caracterização dos potenciais energéticos teórico, realizável e de mercado 
quanto à sua amplitude e suas restrições de aplicação delimitadas nas quatro dimensões de análise e particularizados para cada recurso analisado;

- Aplicação do Modelo em Caso Piloto: aplicação restrita do modelo em caso real, por meio de um exercício de formulação do PIR para a Região Administrativa de Araçatuba, considerando a utilização de ferramentas de Avaliação dos Custos Completos, Cálculo de Potenciais Energéticos e Elaboração de Cenários de Projeção do Consumo Energético para um horizonte de tempo determinado. Estes cenários são desenvolvidos a partir de hipóteses referenciais (considerando a manutenção de parâmetros atuais de consumo energético durante o horizonte de análise, também conhecidos como cenários Business As Usual), conservadoras (contemplando índices intermediários de aumento de eficientização energética) e sustentáveis (considerando uma adoção integral de ações e equipamentos energeticamente eficientes). 


\section{Planejamento Integrado de Recursos}

\subsection{Desenvolvimento Sustentável}

A energia, independentemente de sua origem ou proveniência, é um fator determinante ao desenvolvimento, tanto econômico quanto social de uma nação. Os serviços energéticos são responsáveis pelo atendimento das necessidades do ser humano e da sociedade como um todo; seu bem estar depende diretamente de benefícios extraídos de ecossistemas e dos respectivos serviços proporcionados pelos mesmos [3]. Entretanto, o aumento da população mundial e da atividade econômica relacionada alavancam a demanda por recursos energéticos. Como conseqüência, uma série de alterações nos ecossistemas naturais, além de sua capacidade de regeneração, implicam, tanto de forma direta quanto indireta, em diversos impactos negativos, não apenas de ordem ambiental, mas de repercussão em esferas sociais e políticas.

Diante desta série de impactos negativos, torna-se patente a necessidade de se buscar um ponto de equilíbrio quanto à utilização de recursos naturais, evitando extremos como o uso abusivo e predatório destes recursos, por um lado, e situações de racionamento energético, por outro $[4,5]$. O desenvolvimento mundial nesse ponto de equilíbrio é o que pode ser chamado de desenvolvimento sustentável, e implica na utilização dos recursos naturais de forma responsável e coerente, visando tanto a satisfação das necessidades humanas atuais, quanto a disponibilidade de tais recursos às gerações futuras. Esta definição de Desenvolvimento Sustentável provém do Relatório “Nosso Futuro Comum”, de 1987 [6,7].

Outras definições foram elaboradas, entre elas a de Leroy et alli, caracterizando-o como o "processo de administração de recursos ambientais dentro 
dos princípios éticos e sócio-políticos que orientam sua distribuição" [6]. Ainda, de acordo com o Instituto Internacional de Desenvolvimento Sustentável (IISD), a premissa básica do Desenvolvimento Sustentável é de integrar o gerenciamento responsável de ecossistemas com o desenvolvimento humano, de forma a alcançar o bem estar para gerações presentes e futuras [3].

O atual modelo de desenvolvimento mundial, baseado essencialmente em um modelo de mercado, não respeita tais premissas, provocando uma exploração predatória de recursos naturais e energéticos e uma distribuição desigual de recursos econômicos. O crescimento econômico em diversas partes do globo não é acompanhado por parâmetros igualmente importantes como o acesso à saúde e educação, e principalmente o bom funcionamento de ecossistemas [8]. Em países desenvolvidos, o gerenciamento de impactos ambientais é trabalhado aos poucos, por meio de diversas ações. Já em países em desenvolvimento, a questão ambiental ainda não pode ser satisfatoriamente atendida diante de diversas prioridades de ordem econômica, social e política.

Assim, o conceito de desenvolvimento sustentável em termos da preservação de necessidades de gerações futuras perde força em um contexto no qual ainda se busca a satisfação de necessidades presentes primordiais. Pode-se apontar a existência de uma demanda reprimida, não apenas de energia, mas de necessidades humanas básicas, em boa parte do globo terrestre, tanto para a busca de um maior conforto quanto para o suprimento de necessidades básicas. E este nível de demanda tende a se manter, pelo menos a médio prazo, ainda que ações corretivas sejam tomadas no presente [2].

É vital para o futuro da economia, do meio ambiente e da sociedade como um todo, não apenas assegurar a disponibilidade desta energia a toda a população 
mundial, como também usufruí-la da forma mais racional e eqüitativa possível, identificando e mitigando impactos relacionados à sua obtenção e disponibilização. Criar condições para atender às necessidades das populações, sem comprometer os recursos naturais para as gerações futuras, constitui um grande estímulo para se desenvolver novas tecnologias, sistemas e alternativas de gestão. A atividade sócioeconômica deve, portanto, promover mecanismos de desenvolvimento limpo e conciliar recursos não-renováveis disponíveis atualmente com recursos renováveis potencialmente adotáveis em um momento futuro.

\subsection{Planejamento Energético}

O planejamento tradicional administra a provisão de energia através de métodos e técnicas de previsão de carga relacionando-as com previsões de oferta. Tais análises têm por objetivo a verificação das quantidades necessárias de recursos energéticos, a identificação das alternativas tecnicamente viáveis para seu suprimento e a busca das alternativas de menor custo efetivo de implantação e operação. Nesta abordagem, impactos nos meios ambiental e social não costumam receber a mesma atenção e tratamento analítico que recebem questões técnicas e econômicas. A energia, porém, enquanto meio de provisão de satisfação de necessidades humanas e vetor de desenvolvimento, não apenas econômico como social, deve receber uma análise que ultrapasse o âmbito técnico-econômico.

Desta forma, é imprescindível considerar um processo de planejamento que contemple o suprimento e o uso final da energia de forma integrada, considerando todos os implicantes envolvidos na cadeia energética, como fontes energéticas, usos finais, produtores e consumidores. Com isto pretende-se equacionar de forma equilibrada a demanda reprimida e crescente de energia, o desenvolvimento 
econômico e os impactos ambientais, privilegiando recursos capazes de reduzirem custos e riscos futuros, tanto em termos de geração, como de co-geração e demanda [6].

A abertura dos mercados de energia a empresas privadas e a competição na indústria energética, além da reestruturação do planejamento de médio e longo prazo e do restabelecimento das condições de equilíbrio entre oferta e demanda, fundamentos do atual modelo energético nacional, determinam mudanças na forma tradicional de aprovisionamento de energia. O setor energético deve adaptar-se a mudanças graduais relacionadas a restrições ambientais severas e à participação ativa da sociedade como elementos determinantes à aprovação e viabilização de um empreendimento energético [5]. A gestão de tais mudanças conduz à procura de abordagens baseadas na consideração das particularidades brasileiras, regionais e locais da forma mais abrangente possível, buscando identificar e gerenciar riscos anteriormente desconsiderados, como o ambiental, o social e o político, tendo como meta a viabilidade de empreendimentos energéticos de médio e longo prazo.

\subsection{Características do Planejamento Integrado de Recursos}

Diferentes abordagens de planejamento energético surgiram nas últimas décadas, visando lidar, de forma efetiva e abrangente, com questões particulares ao setor. O PIR - Planejamento Integrado de Recursos - é uma delas, e sua principal característica a partir de sua concepção foi o de equalizar a importância dos recursos de oferta e de demanda no planejamento energético, trabalhando-os de forma integrada, enquanto recursos energéticos. O GEPEA - Grupo de Energia do Departamento de Energia e Automação Elétricas da Escola Politécnica da Universidade de São Paulo - vem expandindo e trabalhando a metodologia do PIR e 
as premissas do Desenvolvimento Sustentável em uma acepção própria, procurando abranger, de forma indiscriminada, elementos políticos, sociais, ambientais e econômicos implicantes em empreendimentos energéticos de oferta e ações referentes à demanda [2]. As principais premissas do PIR são, basicamente:

- Inclusão de todas as opções de recursos energéticos em um dado empreendimento (mesmo que, à primeira vista, algumas opções pareçam desfavoráveis);

- Integração na análise dos lados da oferta e da demanda para o atendimento de necessidades humanas, considerando ambos os recursos, de forma imparcial, no planejamento energético;

- Análise de recursos sob uma perspectiva holística (na qual aspectos ambientais, sociais e políticos são tão importantes à caracterização de um recurso quanto aspectos econômicos). Tal caracterização integrada permite enumerar os diferentes impactos (ou custos) de uma dada alternativa energética. O somatório de tais impactos é chamado de custo completo; a classificação ou rankeamento de tais opções, de menor a maior custo completo, determina a integração dos respectivos recursos no processo de PIR;

- Inclusão formal, na avaliação e tomada de decisão em um determinado empreendimento, de todos os agentes envolvidos e interessados no processo, sejam eles geradores, investidores, grupos populacionais diretamente afetados ou a sociedade como um todo. Desta forma, o processo de PIR é de caráter socialmente participativo, buscando, através da participação qualificada dos envolvidos-interessados (En-In), contemplar e 
tratar, de forma ordenada, diversos problemas de ordem social e ambiental relacionados à provisão de energia;

- Busca do Desenvolvimento Sustentável, através da proposição de novos paradigmas em relação à obtenção e à utilização da energia, bem como o equacionamento de pressão sobre os sistemas ambiental e social.

O diagrama abaixo ilustra a representação das principais premissas do PIR em suas etapas e o encadeamento do processo, considerando a modelagem de recursos do lado da oferta e da demanda, a incorporação dos En-In no processo de planejamento, a integração de recursos e a execução do plano preferencial. 


\section{Diagrama PIR}

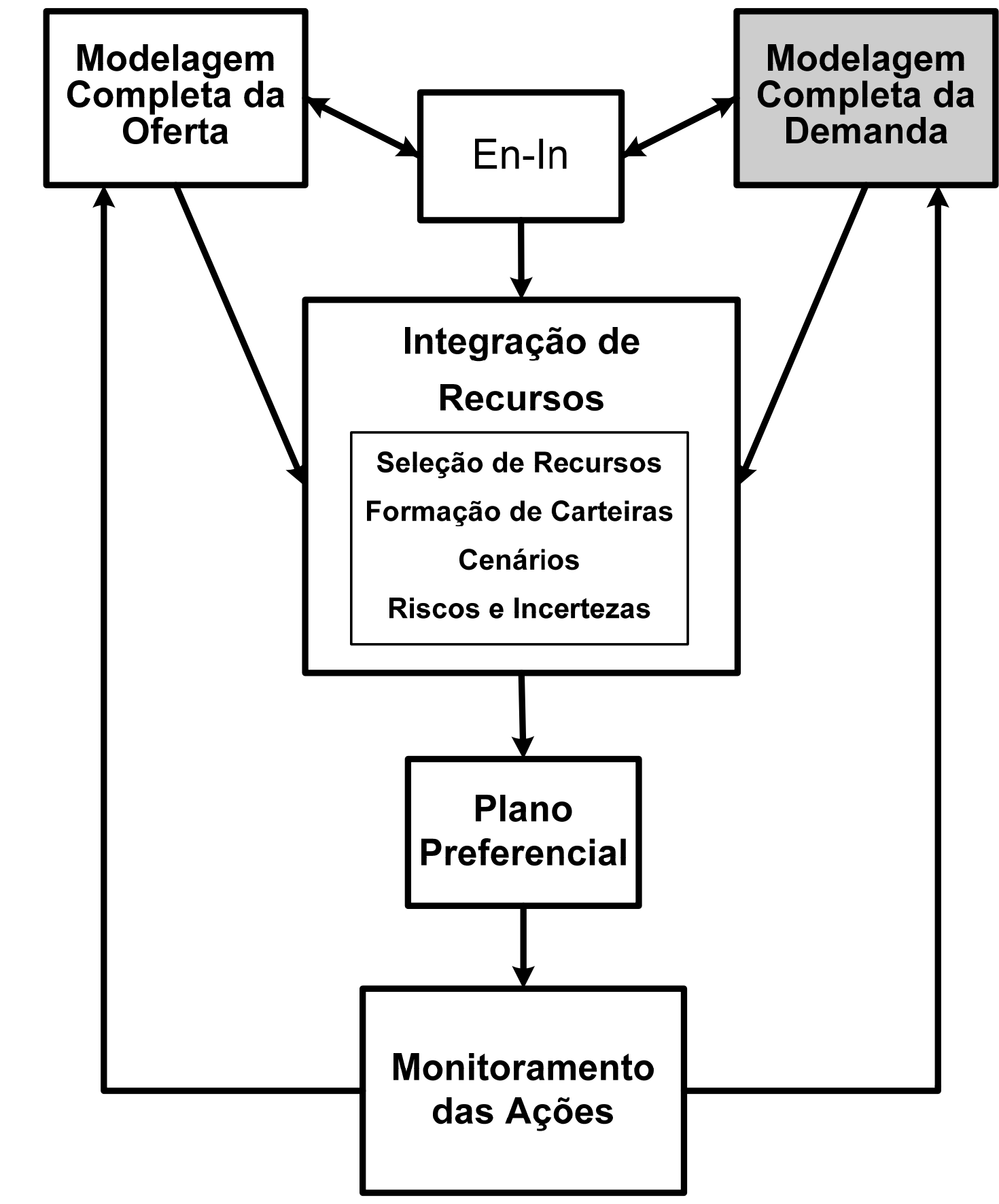

Figura 2.3: Diagrama do Planejamento Integrado de Recursos

O processo de PIR relaciona as quatro dimensões de análise de forma integral e não hierárquica, proporcionando, em diversas situações, resultados em que alternativas aparentemente consideradas mais vantajosas recebem avaliações 
gerais menos favoráveis, em vista de seus desempenhos no campo social, ambiental e político. Tal avaliação permite principalmente identificar, antes de sua implantação, vantagens e desvantagens associadas a um determinado recurso energético e, assim, gerenciar previamente impactos positivos e negativos referentes à sua inserção. Os benefícios da identificação prévia dos impactos são a possibilidade de adequação de determinadas alternativas na fase de projeto, dentro de um grau de precaução, a fim de evitar medidas corretivas posteriores, aumentando assim a probabilidade de êxito de um dado empreendimento.

A proposta atual do PIR é de fornecer uma avaliação que explicite os impactos, benefícios e riscos das diversas alternativas energéticas de determinada região. É um processo flexível, adaptável à geografia da região de estudo e constantemente reavaliado de acordo com o horizonte de planejamento. Este mapeamento completo oferece a toda a sociedade, e principalmente ao investidor, uma visão clara da disponibilidade de recursos energéticos, tanto em termos temporais e geográficos, quanto em termos técnicos, de eficiência e de minimização de impactos. A partir disto, pretende-se conscientizar envolvidos e interessados sobre a responsabilização pelos impactos locais e regionais decorrentes da provisão de energia, uma vez que todos usufruem de seus benefícios [6].

Busca-se enfim, com este processo, a proposição de modelos de caracterização de recursos de oferta e demanda globais de energia, considerados em um consumo sustentável, objetivando o aumento de eficiência e aproveitamento energético e o atendimento às complexas demandas de energia pelos diferentes segmentos da sociedade. A partir disto, espera-se definir um modelo de caracterização e avaliação energética que possa ser aplicado a diversas regiões do país. 


\subsection{Introdução ao Modelo de Caracterização de Recursos de Demanda}

Uma das características essenciais do PIR, conforme dito, é a avaliação conjunta de recursos energéticos do lado da oferta e da demanda. Desta forma, qualquer que seja a procedência de um recurso energético, este exerce a função de disponibilizar energia, seja através de geração ou através de medidas de eficientização dos usos finais.

A energia conservada ou economizada, obtida através do Gerenciamento do Lado da Demanda é vista no PIR como um recurso, equivalente aos recursos de suprimento, através do qual é possível: a postergação de investimentos no setor energético bem como seus conseqüentes impactos ambientais; o uso racional de recursos naturais e o atendimento a parte do crescimento da demanda. O custo desse gerenciamento, de acordo com inúmeros estudos e projetos de eficientização energética, é bastante inferior ao da ampliação da oferta energética, posto que a energia de uso final, disponível para consumo, deriva dos demais processos da cadeia produtiva de eletricidade.

Assim, o Modelo de Análise de Recursos do Lado da Demanda a partir de sua caracterização e avaliação, pretende considerar os diversos custos e benefícios de alternativas energéticas de demanda nas dimensões social, política, ambiental e técnico-econômica, permitindo, no processo de planejamento, uma avaliação de viabilidade menos restrita e mais condizente com o paradigma atual e com tendências de desenvolvimento limpo e sustentável. A análise de recursos passa por uma ponderação de todos os seus atributos (fatores positivos e negativos) nos quatro campos citados e pela estimativa de seu potencial energético, tanto em 
termos teóricos quanto em termos factíveis de implantação, considerando suas restrições e limitações referentes a cada uma das quatro dimensões de análise.

Para a Caracterização e Análise de Recursos Energéticos de Demanda são levantados, analisados e caracterizados todos os recursos e tecnologias relacionadas ao gerenciamento da demanda energética. Os recursos são descritos e discriminados de acordo com grupos de medidas e tecnologias, e suas respectivas aplicações nos diversos setores energéticos. Tais recursos são, desta forma, classificados e organizados para que sejam submetidos a uma análise completa (envolvendo quatro dimensões de avaliação, divididas em atributos e sub-atributos) que permitirá apontar impactos positivos e negativos referentes à sua adoção.

Após esta etapa, procede-se à formulação e à delimitação dos Potenciais Energéticos Teórico, Realizável e de Mercado de recursos do lado da demanda. Primeiramente são determinados procedimentos para a estimativa dos potenciais teóricos dos recursos caracterizados, ou seja, potenciais absolutos de utilização de recursos energéticos, negligenciando limitações de ordem técnica ou geográfica. Em seguida, são definidos potenciais realizáveis ou práticos, incorporando diversas restrições de ordem técnica, operacional, econômica, assim como obstáculos referentes a impactos ambientais. Por último, o potencial de mercado incorpora impactos sociais, pressões dos diversos atores energéticos envolvidos e incertezas dinâmicas de mercado. Este potencial pretende indicar as reais possibilidades de implantação e realização de iniciativas de GLD para o instante considerado de análise.

O modelo de análise de recursos do lado da demanda pode contar com diferentes ferramentas práticas para a elaboração do cômputo das avaliações e a mensuração dos potenciais energéticos. Em nosso caso utilizaremos, para o Estudo 
de Caso, ferramentas consolidadas no Planejamento Integrado de Recursos, como a Avaliação dos Custos Completos e o Cálculo de Potenciais Energéticos.

Conforme visto na Figura 2.3, dentro da premissa do PIR de avaliação conjunta e eqüitativa entre recursos de oferta e demanda, é possível aliar este modelo a um modelo de análise de Recursos Energéticos de Oferta, e assim constituir uma das etapas fundamentais do PIR, de Integração de Recursos de Oferta e Demanda. Abaixo, na Figura 2.4, tem-se um diagrama da Modelagem Completa e Análise dos Recursos Energéticos do Lado da Demanda, mostrando as etapas do modelo, suas inter-relações e a ordem hierárquica de elementos de cada etapa. 


\section{Diagrama Modelagem Completa da Dem anda}

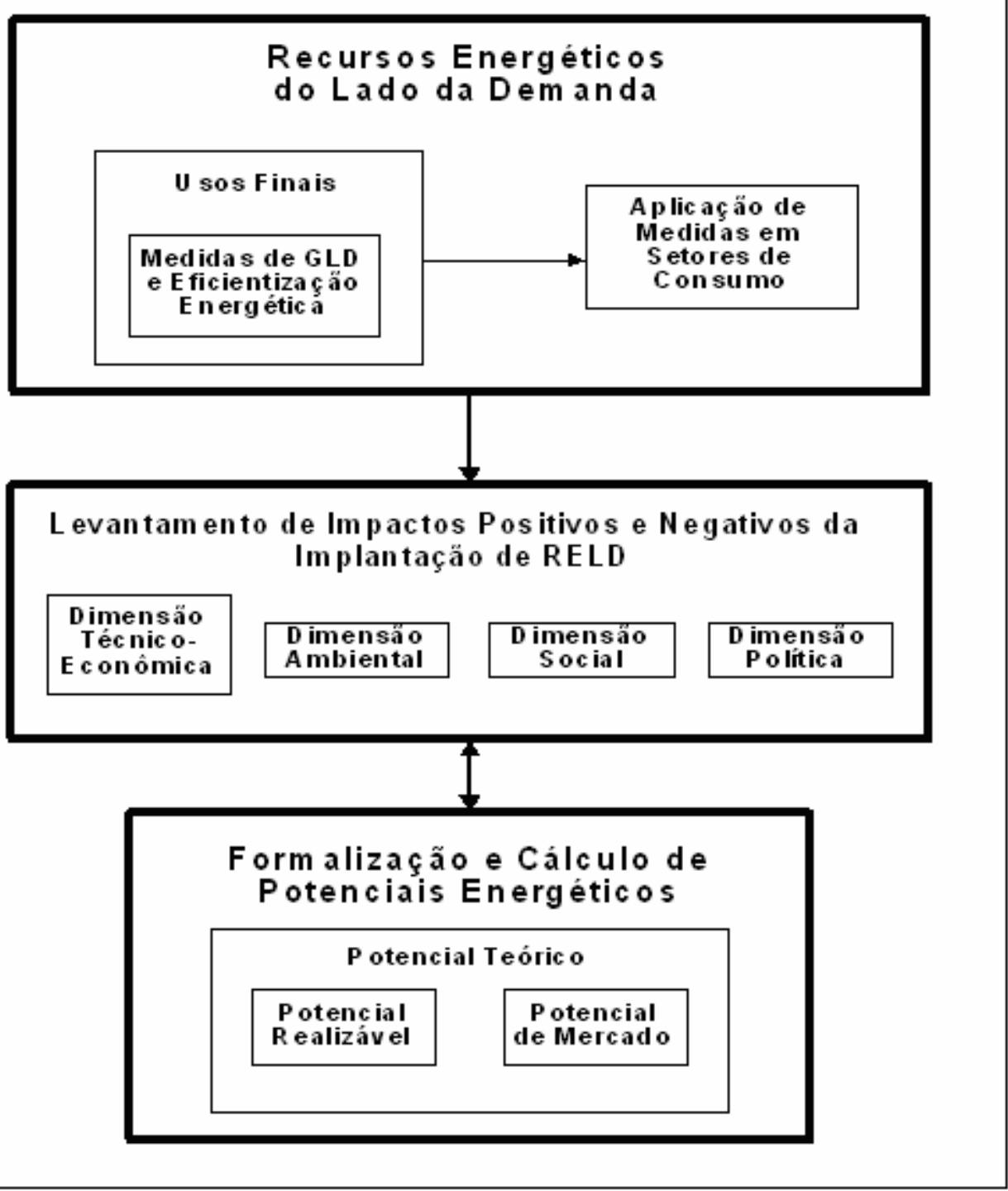

Figura 2.4: Diagrama da Modelagem Completa e Análise dos RELD 


\section{Modelo de Caracterização e Análise de Recursos de Demanda}

Como introdução à descrição e explanação do Modelo, é relevante caracterizar alguns conceitos e premissas relativos ao Gerenciamento pelo Lado da Demanda, ressaltando implicações e benefícios do mesmo, não apenas ao PIR, mas ao planejamento e a conservação energética como um todo.

\subsection{Gerenciamento pelo Lado da Demanda}

\subsubsection{Introdução}

O gerenciamento pelo lado da demanda (GLD) pode ser considerado como um componente fundamental no planejamento energético, principalmente no âmbito do PIR, e consiste no conjunto de ações e programas de controle de consumo e demanda energéticas, tanto direcionadas à distribuição da energia das concessionárias quanto ao consumidor e ao uso final de energia. Estes programas compreendem atividades referidas à gestão da carga e à conservação estratégica, estendendo-se também à substituição do uso de combustíveis e a medidas regulatórias e de tarifação energética [8].

Dentre os principais agentes condutores de programas de GLD pode-se citar as concessionárias, o governo, organizações não-governamentais e empresas de serviços energéticos. A partir destas ações, provocadas ou estimuladas indiretamente por concessionárias, objetiva-se modificar as quantidades e os períodos de utilização da energia, de acordo com a minimização de custos efetivos e impactos relacionados à mesma. Assim, o consumo também pode ser reduzido através de melhorias de ordem técnica e eficiência operacional no uso da energia elétrica. 
A seguir, tem-se uma breve descrição dos diferentes tipos de gerenciamento de carga, quanto aos seus métodos e objetivos.

\subsubsection{Tipos de Gerenciamento de Carga}

\subsubsection{Redução de Pico}

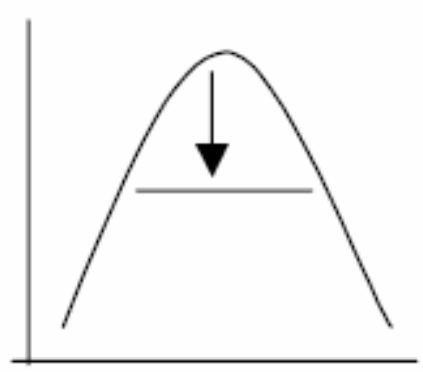

Figura 3.1.2.1: Redução de Pico

A redução da demanda em horários de pico, ou corte de ponta, é uma medida eficiente em termos técnicos e econômicos. Em termos técnicos visa aliviar a carga em períodos de alta demanda, e em termos econômicos possibilita uma redução na conta de eletricidade como resultado da contratação de um nível inferior de demanda. Esta modalidade de controle de carga tem aplicação entre grandes consumidores, em casos onde há diferenciação da tarifa conforme a demanda contratada, como nos setores comercial e industrial. No setor residencial, o uso de controladores de demanda não repercute em vantagens econômicas para o consumidor residencial, dada a inexistência de tarifas diferenciadas pela demanda. Contudo, é uma medida favorável ao sistema elétrico, na medida em que é capaz de proporcionar benefícios técnicos ao evitar sua sobrecarga.

Pode-se conseguir a redução de pico na carga por meio de tarifas diferenciadas no tempo, armazenamento de calor ou controladores de demanda. 


\subsubsection{Conservação estratégica}

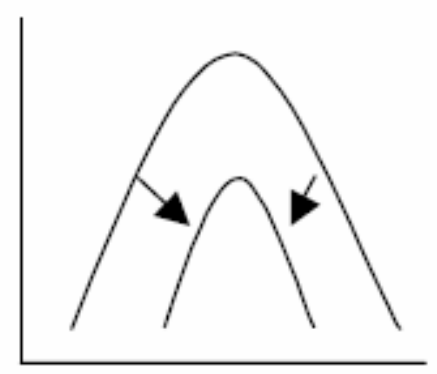

Figura 3.1.2.2: Conservação estratégica

Esta alteração da curva é proporcionada pela redução geral do consumo, e não está restrita a apenas determinado período do dia. Este tipo de redução pode ser proporcionado através de medidas de eficientização para todos os setores de consumo, como a substituição de equipamentos de usos finais pouco eficientes, a utilização de outros recursos energéticas em substituição ao uso da rede (como a energia solar alimentando painéis ou coletores, ou a energia proveniente de combustíveis fósseis transformada a partir de geradores), a aplicação de medidas de arquitetura bioclimática e eficientização de edificações ou ainda a utilização de tarifas variáveis segundo blocos de consumo.

\subsubsection{Preenchimento de Vales}

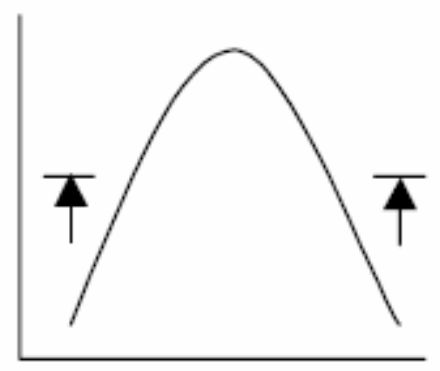

Figura 3.1.2.3: Preenchimento de Vales

O preenchimento de vales, da mesma forma que o deslocamento de pico, pode ser alcançado por meio de medidas como o armazenamento de energia 
(deslocando o consumo para horários de menor demanda da rede) e tarifas diferenciadas (por horários ou períodos do dia). O preenchimento de vales, ou seja, o aumento do consumo energético em horários menos requisitados do dia, pode ser interessante em casos nos quais o custo marginal de energia supera os custos médios [10].

\subsubsection{Crescimento Estratégico da Carga}

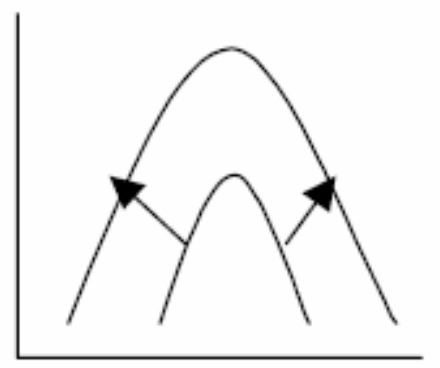

Figura 3.1.2.4: Crescimento Estratégico

O Gerenciamento da Demanda não está, obviamente restrito a medidas de redução de demanda e consumo energéticos. Pode-se obter uma elevação estratégica da carga a partir do crescimento do consumo de energia em período integral, ocasionado, entre outros motivos, por tarifas que incentivem o consumo, pelo desenvolvimento de novas tecnologias industriais intensivas no uso de energia elétrica, entre outros [10].

\subsubsection{Deslocamento de Carga}

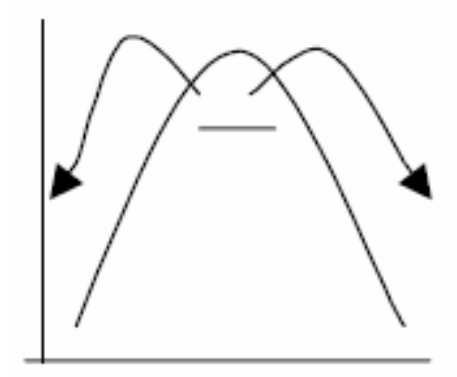

Figura 3.1.2.5: Deslocamento de Carga 
O deslocamento de carga pode ser obtido através de medidas como o armazenamento de calor ou frio (deslocando o consumo referente a usos finais de aquecimento ou refrigeração para horários de baixa demanda da rede, preferencialmente o período noturno), o controle do uso de equipamentos por ciclos alternados de funcionamento e o emprego de tarifas variáveis no tempo [10].

\subsubsection{Curva de Carga Flexível}

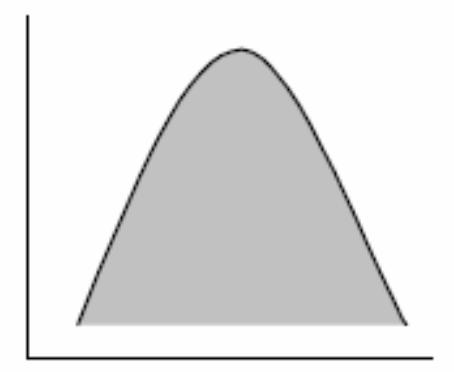

Figura 3.1.2.6: Curva de Carga Flexível

Esta forma de gerenciamento de carga é realizada por meio de serviços de subscrição de demanda customizados, como tarifações de interrupção, que oferecem ao consumidor diferentes níveis de confiabilidade (de acordo com diferentes freqüências de interrupções programadas e especificadas de energia) em troca de cobranças reduzidas de demanda contratada.

\subsubsection{Objetivos do Gerenciamento do Lado da Demanda}

O GLD, além de simplesmente uma medida emergencial de suprimento, deve ser considerado como elemento essencial ao planejamento energético, respondendo às necessidades de expansão do sistema local, regional e nacional. Analisando a cadeia energética e o planejamento energético como um todo, observa-se que o risco de se ampliar a oferta energética a partir de táticas correntes de construção de novas usinas é proporcional ao fator de incertezas inerente a projeções futuras de demanda [10]. Assim, a integração do controle ativo da demanda ao processo de 
planejamento energético é imprescindível, tanto como instrumento de minimização de riscos de suprimento, quanto como forma de disponibilização de energia a menores custos econômicos (através de benefícios tarifários aos consumidores) e ambientais (conservando recursos energéticos e minimizando danos ao meioambiente).

Tais objetivos vão de encontro à filosofia do desenvolvimento sustentável e especialmente do PIR, no qual o GLD é analisado conjuntamente com o GLO (Gerenciamento pelo Lado da Oferta), sendo ambos balizados pela visão dos custos completos (ACC). O GLD representa uma ação com vistas ao Desenvolvimento Sustentável na medida em que poupa recursos energéticos cada vez mais escassos e preza pela satisfação das necessidades do serviço energético da sociedade como um todo.

\subsubsection{GLD no Brasil}

No Brasil, e nos demais países em desenvolvimento, verifica-se um crescente consumo de energia elétrica, apesar de recorrentes períodos de instabilidade econômica. De acordo com projeções realizadas no Plano 2015, o consumo nacional seria de aproximadamente 780 TWh nesse ano [11]. Comparado ao consumo atual de 30,9 milhões de tep (de acordo com o Balanço Energético Nacional de 2005), ou superior a 380 TWh, teríamos um consumo nacional duplicado em um período de dez anos.

A partir dessa perspectiva, a Eletrobrás vem promovendo, desde 1985, campanhas e medidas de conservação de energia elétrica. Por meio do Procel (Programa Nacional de Conservação de Energia Elétrica) foram criados diversos programas de eficientização energética voltados para diferentes setores de consumo e usos finais como a iluminação pública, edificações, setores comercial e 
industrial, e educação, entre outros. A partir de tais medidas, o Procel estima uma redução energética de até 130 TWh, o que equivaleria ao dobro da produção aproximada da Usina de Itaipu.

$\mathrm{Na}$ parte de combustíveis, deve-se mencionar também as campanhas do CONPET (Programa Nacional de Uso Racional de Derivados de Petróleo e de Gás Natural) [12] voltadas ao setor de transportes (consumo eficiente de combustíveis), aos setores comercial e residencial (etiquetagem de fogões e aquecedores) e ao industrial (cogeração e fixação de índices de eficiência energética), além de projetos institucionais de educação.

\subsubsection{GLD nos EUA}

Nos EUA, até o final da década de 80 , as concessionárias americanas estruturavam-se da forma tradicional: verticalizadas da geração à distribuição; reguladas por comissões públicas que asseguravam uma certa taxa de retorno em troca do cumprimento de princípios acordados de gerência e desempenho; regime de monopólio natural.

Até então, o interesse básico das concessionárias era administrar sua curva de carga de maneira racional, de onde consolidaram-se programas de GLD. As principais ações que constituíam tais programas, na maioria das vezes, concorriam com outros projetos de aumento da oferta, e eram naturalmente precedidas de criteriosas avaliações do tipo custo/benefício.Essa política ganhou força na medida em que as comissões reguladoras autorizavam a capitalização dos investimentos em GLD como se fossem projetos de expansão da oferta. Uma característica importante do GLD é que suas ações visavam resultados imediatos, com impactos técnicoeconômicos de curto prazo, cujo horizonte em geral era de um ano. 
A partir dos anos 90, esse cenário se altera radicalmente: a emergência das novas tecnologias de ciclo combinado, associadas à redução do preço do gás natural tornam o suprimento de energia elétrica abundante; o crescimento da demanda ocorre em níveis moderados; inúmeros estados iniciam um processo de desregulamentação, reestruturação e privatização; novas entidades prestadoras de serviço chegam ao mercado. Por fim, a desverticalização das concessionárias, transformando as áreas de geração, transmissão e distribuição em empresas distintas, contribui para desfazer a lógica inicial do processo, na qual o gerenciamento do lado da demanda implicava na redução ou postergação dos investimentos no lado da oferta [13].

\subsubsection{A Desverticalização das Empresas Elétricas e o GLD}

O processo de desverticalização das empresas elétricas, iniciado a partir da reestruturação do Setor Elétrico nacional, no qual separaram-se as atividades de geração, transmissão e distribuição de eletricidade, tornou mais difícil a adoção de programas de conservação de energia elétrica.

Quando a gestão da geração e a distribuição de energia elétrica eram feitas por uma única empresa, o gerenciamento da demanda encontrava maiores possibilidades de sensibilização e sucesso. O cálculo de demanda economizada, a partir de medidas de conservação, mostrava a viabilidade econômica de programas de conservação frente ao maior custo de ampliação da oferta, por meio da construção de novas plantas de geração.

O processo de privatização, no entanto, desarticulou as possibilidades de sucesso de alternativas de GLD, na medida em que, nesse contexto, empresas de distribuição de eletricidade não possuem nenhuma motivação para a implementação de programas de conservação [14]. 
Por um lado a desverticalização das atividades setoriais é capaz de proporcionar transparência na gestão de cada atividade, permitindo ao mercado e à sociedade o conhecimento dos resultados da concessão, além de evitar que recursos de uma atividade de serviço público sejam utilizados em atividades competitivas ou outras, comprometendo a expansão e a melhoria da prestação do serviço concedido. Por outro lado, a desverticalização impossibilita que a receita auferida nas atividades de distribuição seja transferida para investimentos na expansão da oferta. $[14,15]$.

Apesar de sua contribuição decisiva no equacionamento da crise energética de 2001, a conservação de energia vem perdendo o apoio imprescindível de órgãos de governo na sua efetivação. Ainda que os benefícios de ordem ambiental, técnica e econômica do GLD sejam consideráveis, o orçamento atual destinado aos programas representa uma parcela ínfima do valor destinado à expansão [15].

A Resolução número 242 da Aneel, de 24/julho/1998, define a obrigatoriedade de $1 \%$ da receita operacional anual das empresas de distribuição de eletricidade ser destinada "ao desenvolvimento de ações com o objetivo de incrementar a eficiência no uso e na oferta de energia elétrica". Desse total, um mínimo de 0,25\% da receita operacional anual de cada distribuidora de eletricidade deveria ser aplicado em ações que ampliassem a eficiência dos usos finais de energia elétrica. Entretanto, a própria agência encontra dificuldades para identificar a natureza dos programas apresentados pelas empresas, muito dos quais consistindo em simples projetos de substituição de lâmpadas com preços sobrevalorizados, no intuito de alcançar mais facilmente os valores correspondentes a 1\% do faturamento, impostos através de um instrumento de regulação [16]. Foram ainda estabelecidos pela Aneel, novos critérios para a elaboração de programas de eficiência energética das 
concessionárias. De acordo com uma resolução submetida à audiência pública, no mínimo 90\% dos recursos destinados pela Lei 9.991/00 à eficiência energética devem ser aplicados em projetos de perdas comerciais e baixa renda, em detrimento de projetos de educação em eficiência energética e de gestão energética municipal, em decorrência da inexpressividade de resultados obtidos [15]. Assim, pode-se creditar parte das dificuldades de oportunidades de implementação de programas efetivos de conservação à falta de mecanismos de controle social sobre a aplicação destes recursos [16].

\subsubsection{Perspectivas do GLD}

Nos EUA, o regime competitivo no mercado de energia elétrica provocou uma retração sensível nos investimentos em GLD das concessionárias, principalmente nos programas que envolviam incentivos financeiros (rebates) ou instalação direta (doação). Renasceram, no entanto, programas de menor custo envolvendo campanhas informativas ou financiamento de equipamentos eficientes, sobretudo devido ao reconhecimento da importância de se manter - ou conquistar - a simpatia e preferência dos consumidores. Assim, se o GLD institucional perde espaço, outros mecanismos alternativos como o marketing e campanhas promocionais compartilhadas ganham importância na estratégia comercial das concessionárias. [13]

A experiência internacional, em especial na Europa e nos EUA, tem mostrado que, em ambientes competitivos muitos programas de GLD não têm obtido sucesso, dada a baixa de preços de novas formas de suprimento, tornando o GLD menos atraente a médio e longo prazo em termos de custo efetivo [10]. É importante lembrar que o GLD compete, nestas situações, com outras opções de disponibilização de energia, como a compra de energia de outras concessionárias 
ou de produtores independentes, a repotenciação de usinas existentes, além de melhoras nos sistemas de transmissão e distribuição.

Entretanto, compromissos decorrentes do Protocolo de Kyoto já provocam pressões por parte do governo e de comissões regulatórias em relação aos geradores de energia, no tocante à redução de emissões de poluentes $\left(\mathrm{CO}_{2}, \mathrm{NO}_{\mathrm{x}}\right.$, $\mathrm{SO}_{x}$, etc.) definindo, inclusive, frações de suas receitas a serem investidas em eficiência energética e fontes renováveis [49]. Em nível nacional, o aumento de pressões ambientais deve ser um ponto altamente favorável à eficiência energética no futuro.

Outro aspecto que pode motivar investimentos em eficiência energética por parte de empresas energéticas é a possibilidade de agregar valor ao serviço oferecido. Os consumidores vêm se tornando mais conscientes quanto a aspectos referentes à qualidade do produto e tratamento personalizado. Adicionalmente, a crescente competitividade do setor deve conduzir ao desenvolvimento de serviços a custos mais baixos. Gradativamente os consumidores tornam-se mais conscientes de seus direitos, exigindo tratamento personalizado e de melhor qualidade.

Apesar das tendências do setor elétrico e dos pontos desfavoráveis ao GLD a partir de experiências internacionais, a viabilidade do GLD no caso nacional deve sempre tomar em conta particularidades da nossa realidade, principalmente quanto a pontos como a existência de demanda reprimida, a possibilidade futura de novas situações de racionamento energético, além de um grau diferenciado de desenvolvimento e domínio tecnológico tanto em relação a recursos do lado da demanda, quanto em relação a novas formas de suprimento. 


\subsection{Etapas do Modelo de Caracterização e Análise de RELD}

O Modelo de Caracterização e Análise de Recursos Energéticos do Lado da Demanda proposto está ordenado nos seguintes procedimentos seqüenciais:

1. Inventário de Recursos de Demanda: Caracterização dos diversos recursos energéticos do lado da demanda, segmentados em medidas ou ações, setores energéticos e tecnologias de usos finais. Neste segmento, os recursos são classificados de acordo com ações de implantação, que podem ser desde educativas, informativas ou regulatórias até medidas de seleção de equipamentos e combustíveis eficientes. Tais recursos são balizados de acordo com referenciais temporais e espaciais, modificadores naturais de disponibilidade energética.

2. Caracterização das Dimensões de Avaliação: Nesta etapa, uma vez discriminados os recursos, são levantados todos os atributos relevantes para sua análise, dentro de quatro dimensões fundamentais vinculadas ao desenvolvimento sustentável: técnico-econômica, política, social e ambiental. Os atributos de análise levantados são caracterizados e, de acordo com a necessidade, segmentados em diferentes níveis de sub-atributos. A profundidade da caracterização estará relacionada à exeqüibilidade da valoração de recursos do lado da demanda. A delimitação das condições de contorno de cada dimensão de análise é extremamente importante, para evitar que atributos híbridos quanto a sua natureza sejam avaliados repetidamente, tendenciando a classificação e o desempenho de um dado recurso. 
3. Formulação e Delimitação dos Potenciais Energéticos: Procede-se, nesta etapa, à estimativa do potencial global de cada recurso de demanda para uma dada região de estudo. O potencial teórico engloba todas as possibilidades que o recurso energético pode oferecer, independentemente de limitações ou empecilhos de ordem geral, sejam eles técnico-econômicos, geográficos, naturais ou temporais. O potencial realizável provém de uma análise ponderada acerca das perspectivas de utilização de um dado recurso na região de estudo, já incluindo restrições de natureza técnica, econômica e de fatores ambientais. Já o potencial de mercado inclui fatores dinâmicos, que comportam alto grau de incerteza, como questões políticas e sócio-culturais, representando na análise, a percepção dos envolvidos e interessados na questão energética local.

4. Aplicação do Modelo em caso real: $O$ modelo de análise de recursos de GLD é validado no âmbito do PIR por meio de ferramentas consolidadas no planejamento, como a Avaliação dos Custos Completos (ACC), o Cálculo de Potenciais Energéticos (Teórico e Realizável) e a Elaboração de Cenários Energéticos para a Projeção de Demanda e a Programação de Inserção de medidas de GLD $[1,6,18]$.

Estas etapas estão descritas em capítulos separado, com o intuito de explicitar os diferentes passos do modelo. Assim, no Capítulo 4 são introduzidos os principais grupos e tipos de recursos do lado da demanda, no Capítulo 5 são descritas as dimensões e os diferentes critérios que comporão a análise destes recursos, no Capítulo 6 tem-se o procedimento de formulação e delimitação dos Potenciais Energéticos de Recursos de GLD e, por fim, no Capítulo 7, ocorre o exercício de Aplicação do Modelo em Caso Real, na Região de Araçatuba. 


\section{Recursos Energéticos do Lado da Demanda}

\subsection{Formalização de Recursos Energéticos do Lado da Demanda}

Entende-se como um recurso energético do lado da demanda a aplicação do Gerenciamento do Lado da Demanda em usos finais, elo final da cadeia energética, para os diversos setores econômicos. Estas ações e medidas são aplicadas a equipamentos e tecnologias de uso final, desde eletrodomésticos a motores industriais, bem como a substituição de combustíveis ou a adoção de projetos energeticamente eficientes. Assim, um recurso do lado da demanda pode ser compreendido como a combinação de:

\section{Usos finais (Tecnologias) + Medidas / Ações de GLD}

aplicável aos diferentes setores de consumo.

Para uma melhor condução do processo de análise dos recursos do lado da demanda, é necessário organizá-los em grupos hierárquicos caracterizando os usos finais energéticos e suas respectivas teconologias, seu relacionamento com os setores econômicos, e as medidas de GLD aplicáveis para cada uso final, dentro de um dado setor de consumo. A seguir, são descritos, em linhas gerais, cada um dos três grupos de especificação de recursos do lado da demanda.

\subsubsection{Usos Finais Energéticos}

Este primeiro nível caracteriza os principais usos finais de energia, como a iluminação, a força motriz, o condicionamento ambiental e o aquecimento de água, bem como os diferentes tipos de equipamentos e tecnologias associados, como refrigeradores, condicionadores, motores, lâmpadas, chuveiros elétricos, entre 
outros. No levantamento destes usos, devem ser descritos os níveis médios de eficiência dos equipamentos, bem como os níveis de consumo de tecnologias atuais mais eficientes.

\subsubsection{Medidas ou Ações de GLD}

A partir dos usos finais e respectivas tecnologias envolvidas, pode-se apontar as medidas mais apropriadas de: gerenciamento da demanda, através do armazenamento de energia e de controladores de demanda; a redução de consumo, pela substituição ou ajuste de equipamentos como motores, refrigeradores, condicionadores ou sistemas de iluminação; o uso racional e consciente de energia, através de incentivos tarifários, campanhas de informação, ou a eficientização do uso através de projetos de edificações eficientes e de arquitetura bioclimática.

\subsubsection{Setores de Consumo}

Neste último nível, são descritos os setores econômicos (comercial, industrial, residencial, público), caracterizados por suas respectivas matrizes de consumo. A partir dos principais usos finais de cada setor, é possível delinear as medidas de GLD mais adequadas a cada um, visando a obtenção de reduções de consumo.

Assim, são descritos, nas próximas sessões, todos estes grupos de especificação de recursos do lado da demanda. Primeiramente, procede-se à discriminação dos diferentes usos finais e suas respectivas tecnologias. Em seguida, são descritas as diferentes medidas de GLD possíveis de aplicação. Por fim as medidas são alocadas nos diferentes setores de consumo, de acordo com sua aplicabilidade. 


\subsection{Usos Finais e Tecnologias}

O principal objetivo do uso da energia é assistir na satisfação das necessidades e desejos do ser humano. O que se deseja porém, não é a energia em si, mas os serviços energéticos proporcionados pelas tecnologias de uso final. Estes são responsáveis pelo suprimento das principais necessidades sociais, como o condicionamento ambiental, o aquecimento de água, a iluminação, a cocção, o transporte e a força motriz, concretizados através de tecnologias de uso final, como lâmpadas, fogões, refrigeradores, veículos, entre outros, alimentados por energias secundárias como a elétrica ou de óleos combustíveis.

A seguir são descritos os principais grupos de usos finais, bem como as respectivas tecnologias a eles associadas.

\subsubsection{Iluminação}

A iluminação é um dos mais expressivos usos finais, respondendo por cerca de $40 \%$ do consumo de eletricidade no setor comercial e acima de $20 \%$ do consumo total de energia elétrica no setor residencial. No setor público, dois terços da eletricidade consumida são destinados à iluminação de ruas.

$\mathrm{Na}$ avaliação de fontes luminosas temos como parâmetros importantes o fluxo luminoso, a eficiência luminosa e a iluminância. O fluxo luminoso caracteriza a quantidade de luz produzida por uma lâmpada, emitida pela radiação, medida em lúmens (Im). A eficiência luminosa é o quociente entre o fluxo luminoso total emitido e a potência consumida, medido em lúmens por Watt. Já a iluminância é o fluxo luminoso incidente em função da área iluminada. De acordo com a aplicação da iluminação, níveis diferentes de iluminância são requeridos, de forma a atender a requisitos de desempenho e conforto visual. Tarefas visuais simples demandam uma 
baixa iluminância; tarefas visuais prolongadas ou exatas como cirurgias ou montagens de componentes de microeletrônica demandam um alto nível de iluminância.

Pode-se ver, portanto, que o emprego de uma dada fonte de iluminação está condicionado tanto à sua eficiência energética, quanto à eficiência prática e adequação à atividade específica requerida. Como parte de equipamentos e tecnologias de iluminação, temos lâmpadas, luminárias, reatores, circuitos de iluminação e dispositivos de controle. As lâmpadas se dividem em dois grandes grupos: as incandescentes e as de descarga.

\subsubsection{Lâmpadas Incandescentes}

As lâmpadas incandescentes produzem iluminação a partir da incandescência de um fio, aquecido ao ser percorrido por corrente elétrica no vácuo ou em meio gasoso apropriado. Podem ser do tipo comum, halógena, halógena dicróica e de luz mista. Apresentam níveis de eficiência entre 10 e 27 Im/W [19]. A lâmpada incandescente comum, apesar de possuir a mais baixa eficiência entre todas as lâmpadas (apenas 10\% da energia consumida é transformada em luz) é ainda amplamente usada em ambientes internos como vitrines e indústrias têxteis e gráficas, dada sua boa reprodução de cor. Possui uma potência que pode chegar aos 500W e uma vida útil de 1000 horas [19]. A lâmpada incandescente halógena possui o dobro da vida útil, potência de até 3000 W, e nível similar de eficiência [19]. Por apresentar um fluxo luminoso maior e, por conseqüência, uma maior reprodução de cores, é usada em projetores, na iluminação de fachadas, em faróis de veículos, luzes de orientação, teatros e estúdios. 


\subsubsection{Lâmpadas de Descarga}

As lâmpadas de descarga produzem luz por meio de descarga elétrica contínua em um gás ou vapor ionizado. Funcionam com equipamentos auxiliares como reatores e ignitores. O primeiro limita a corrente da lâmpada e o segundo auxilia a produção da tensão necessária à descarga elétrica. As lâmpadas de descarga dividem-se em dois grupos, de alta e baixa pressão. O primeiro grupo compreende as lâmpadas de mercúrio, sódio, mista e vapores metálicos. O segundo compreende a lâmpada fluorescente de mercúrio e a de sódio de baixa pressão.

O grupo de lâmpadas de descarga de baixa pressão abarca as lâmpadas fluorescentes, nas quais a luz é produzida por pós fluorescentes ativados por radiação ultravioleta de descarga. As lâmpadas fluorescentes tubulares são comumente utilizadas em instalações comerciais, como escritórios, oficinas, hospitais, escolas, entre outras. Possuem uma boa reprodução de cores e uma vida útil de 7.500 horas, que pode ser encurtada em função de acendimentos muito freqüentes. Sua eficiência, que depende da utilização de equipamentos auxiliares adequados, pode chegar aos $75 \mathrm{~lm} / \mathrm{W}$ e a potência, até 110 W [19]. Há uma nova geração de lâmpadas de maior eficiência que possuem tubos de diâmetros menores revestidos com pós especiais, que garantem uma melhor reprodução de cores e uma redução no consumo de energia em torno de $20 \%$.

As lâmpadas fluorescentes compactas são capazes de substituir as incandescentes em diversas aplicações, apresentando o mesmo fluxo luminoso a partir de potências expressivamente menores (100W contra 500W de lâmpadas incandescentes), resultando em uma economia de energia de até $80 \%$, um enorme acréscimo de vida útil (até 12.000 horas contra 1.000 horas de lâmpadas incandescentes) e uma boa definição de cores [19]. 
Quanto a lâmpadas de descarga de alta pressão, os principais tipos são as de mercúrio, mistas e de vapor de sódio. As lâmpadas de mercúrio de alta pressão contam com uma vida útil de 15.000 horas, com depreciação de $30 \%$ do fluxo luminoso nesse período, eficiência inferior às lâmpadas fluorescentes (55 Im/W, [19]) e utilização preferencial em iluminação pública, industrial interna e externa e de fachadas de prédios. Devem ser instaladas a uma altura superior a 4 metros do chão, a fim de evitar ofuscamentos.

A lâmpada mista tem construção e funcionamento similar à de mercúrio de alta pressão, possuindo eficiência e vida útil inferiores, de respectivamente $22 \mathrm{Im} / \mathrm{W}$ e 6.000 horas [19]. A boa reprodução de cores favorece sua utilização em vias e locais públicos, bem como a modernização de instalações com lâmpadas incandescentes. Assim como as lâmpadas de mercúrio, devem ser instaladas a uma altura superior a 4 metros.

As lâmpadas a vapor de sódio de alta pressão também se assemelham às de mercúrio quanto a formato e funcionamento, exceto pelo uso de um ignitor por conta da necessidade de altas tensões para a partida. O brilho máximo e a coloração branco-dourada levam de 3 a 4 minutos para serem atingidos, com diversas mudanças de cor no período. Podem ser utilizadas para iluminação externa, em vias públicas e em iluminação interna industrial. Sua vida útil é extremamente elevada, de 24.000 horas, com uma depreciação de $25 \%$ do fluxo luminoso nesse período. Sua eficiência luminosa é de $120 \mathrm{~lm} / \mathrm{W}$, ou o dobro da eficiência de lâmpadas de mercúrio [19].

A lâmpada de vapor de sódio de baixa pressão tem a descarga elétrica iniciada com o gás neônio, que produz um pequeno fluxo luminoso de coloração rosa. A lâmpada atinge sua condição normal de funcionamento em 15 minutos, 
produzindo um fluxo luminoso de cor amarela, como resultado da descarga no vapor de sódio. A vida útil desta lâmpada é de 15.000 horas, com uma eficiência bastante alta, de $200 \mathrm{Im} / \mathrm{W}$, a mais alta entre todas as lâmpadas descritas [19]. A luz monocromática permite uma aplicação limitada a locais onde não se demanda um alto índice de reprodução de cores, como estradas, portos, entre outros.

Na tabela a seguir pode-se observar um resumo das lâmpadas descritas, por faixa de eficiência.

Tabela 4.2.1.2: Tipos de Lâmpadas e Eficiências Associadas

\begin{tabular}{|l|c|l|l|}
\hline TIPO DE LÂMPADA & EFICIÊNCIA & TIPO DE LÂMPADA & EFICIÊNCIA \\
\hline \multicolumn{2}{|l|}{ INCANDESCENTE } & DESCARGA \\
\hline COMUM & 8 a $18 \mathrm{Im} / \mathrm{W}$ & FLUORESCENTE & 56 a $75 \mathrm{Im} / \mathrm{W}$ \\
\hline HALÓGENA & 17 a $22 \mathrm{~lm} / \mathrm{W}$ & VAPOR DE MERCÚRIO & 40 a $55 \mathrm{~lm} / \mathrm{W}$ \\
\hline HALÓGENA DICRÓICA & $19 \mathrm{Im} / \mathrm{W}$ & VAPOR METÁLICO & 68 a $100 \mathrm{Im} / \mathrm{W}$ \\
\hline LUZ MISTA & 19 a $27 \mathrm{~lm} / \mathrm{W}$ & VAPOR DE SÓDIO & 80 a $125 \mathrm{~lm} / \mathrm{W}$ \\
\hline
\end{tabular}

\subsubsection{Outros tipos de Lâmpadas e Tecnologias}

Em adição a estas lâmpadas, pode-se citar novas tecnologias de iluminação como os LEDs, as lâmpadas de indução e as lâmpadas de enxofre.

Os LEDs, ou Diodos emissores de luz (light emitting diodes) tem uso preponderante em luminosos, semáforos e placas. Em semáforos, é capaz de substituir lâmpadas de $150 \mathrm{~W}$ por discos de 9W, com eficiências de 20 Im/W. Possui uma vida útil variável entre 5 e 20 anos e é uma tecnologia amplamente disponível a custos decrescentes.

As lâmpadas de indução apresentam uma vida útil elevadíssima de 60.000 horas; eficiências similares às de descarga (80 Im/W), baixa perda de fluxo luminoso, alta reprodução de cores, possibilidade de operação em corrente contínua e a vantagem de poderem ser instaladas em locais de difícil acesso à manutenção. 
As lâmpadas de enxofre possuem diversas vantagens em relação às tecnologias correntemente utilizadas, entre as quais: sua eficiência (95 Im/W) é duas vezes maior que das outras fontes de luz branca de alta qualidade, possuem um nível ínfimo de emissão de luz ultravioleta ou infravermelha, não apresentam riscos ao meio ambiente por serem composts de enxofre e argônio, sua qualidade luminosa não decai até o fim da vida útil de 60.000 horas e apresentam altas potências com pouca emissão de calor. Podem ser aplicadas em grandes espaços públicos ou comerciais que requeiram alta qualidade luminosa, indústria de linha de montagem ou frigoríficos.

\subsubsection{Equipamentos e Tecnologias de Iluminação}

Para a eficiência de uma fonte de iluminação e seu respectivo consumo racional de eletricidade, não apenas a lâmpada, como a utilização de luminárias, reatores e dispositivos de controle devem ser considerados.

Os reatores são equipamentos capazes de limitar a corrente na lâmpada e aumentar a tensão de operação para seu funcionamento. Podem ser do tipo eletromagnético ou eletrônico. Os reatores eletromagnéticos consomem uma potência final maior e ainda utilizam uma parcela desta potência para manterem os filamentos das lâmpadas aquecidos, mesmo quando desligadas. Já os reatores eletrônicos são uma evolução do primeiro tipo, permitindo a operação de lâmpadas fluorescentes em potência nominal inferior para uma mesma quantidade de luz emitida, o aumento da vida útil das lâmpadas (dada a operação em altas freqüências) e a redução de distúrbios como o efeito estroboscópico e flicker em monitores de vídeo, a produção de ruídos e o aquecimento do ambiente (por apresentarem perdas consideravelmente menores). 
As luminárias são um elemento fundamental no cálculo de iluminação de um determinado espaço e no direcionamento do fluxo luminoso, tendo como função assegurar o conforto visual com o máximo de eficiência. Podem ser de diferentes tipos, desde embutidas, abertas, fechadas, até projetores e spots. Cada um desses tipos implica em diferentes utilizações, rendimentos e praticidade de manutenção. A manutenção periódica, visando a limpeza das luminárias, é de extrema importância, posto que o acúmulo de poeira reduz a intensidade do fluxo luminoso, ocasionando perdas de luz no ambiente de até $20 \%$.

Sistemas de iluminação controlados eletronicamente oferecem vantagens como menor consumo de energia e maior eficiência luminosa; em contrapartida, implicam em problemas de qualidade elétrica como redução de fator de potência e produção de harmônicos, por se tratarem de cargas não-lineares.

\subsubsection{Refrigeração}

A refrigeração é um uso final de extrema importância para todos os setores de consumo, em processos de conservação de alimentos e manutenção de substâncias e materiais em temperaturas adequadas ou seguras. Representa cerca de $20 \%$ do consumo energético nacional, participando em cerca de um terço do consumo residencial e $17 \%$ do consumo do setor comercial [19]. Refrigeradores podem ser divididos em duas partes fundamentais: o gabinete e o sistema frigorífico.

O gabinete inclui a estrutura do refrigerador, portas, paredes, acessórios, formação de gelo e circulação de ar frio. O gabinete troca calor com o meio exterior através da convecção, nas superfícies interna e externa, e condução, no interior das paredes, variável conforme o tipo de isolante empregado.

O sistema frigorífico funciona majoritariamente a partir de ciclos de refrigeração por compressão. Tais ciclos consistem no princípio da retirada de calor 
do meio por um líquido saturado a alta pressão, que se vaporiza quando sua pressão é reduzida, em um evaporador. O líquido passa por um compressor, no qual passa ao estado de vapor saturado a alta pressão. Em seguida, passa por um condensador, onde rejeita energia térmica ao ambiente e volta à condição de líquido saturado a alta pressão. Por fim, o fluido é expandido na válvula de expansão, reiniciando o processo [20].

Podem ser usados compressores alternativos ou rotativos (vide próximo item), que podem trabalhar de forma mais eficiente a partir da redução de perdas elétricas e magnéticas, folgas e atritos, ou pela adoção de novos materiais e lubrificantes. Os elementos que afetam de forma mais acentuada a eficiência da refrigeração são, portanto, os componentes do equipamento: o compressor frigorífico, o condensador, o evaporador e o isolamento térmico.

O compressor frigorífico pode apresentar perdas na conversão da energia, na eficiência termodinâmica do gás utilizado e na eficiência da compressão do gás. A eficiência do condensador depende de parâmetros como a temperatura média do ambiente, a área de troca (área de dispersão dos condensadores), o material empregado nos condensadores (alta transferência) e a ventilação. O evaporador tem seu desempenho condicionado à temperatura de projeto do refrigerador (TF), o material empregado no evaporador, a área de troca e barreiras físicas como a capa de gelo. Já a performance do isolamento térmico depende da espessura e das propriedades do material isolante.

Como variantes externos ao desempenho geral dos refrigeradores são apontadas, obviamente, as condições climáticas, como o aumento de consumo em épocas ou regiões quentes, e o uso do equipamento, como as condições de instalação, conservação e hábitos de uso. Assim, como principais deficiências em 
relação ao consumo de energia de refrigeradores e sua vida útil, tem-se: níveis inadequados de temperatura de câmaras frigoríficas, inexistência de termostatos (acarretando em funcionamento contínuo e desperdício dos equipamentos), condições e forma de armazenagem de produtos, ausência do ventilador do evaporador (provocando a formação de gelo e o conseqüente aumento de consumo energético), a falta de limpeza do condensador e do compressor, entre outros.

\subsubsection{Condicionamento Ambiental}

O condicionamento ambiental é um uso final de grande utilização em diversos estabelecimentos do setor comercial (com uma média nacional de $20 \%$ de consumo) e também de grande emprego no setor residencial nas regiões brasileiras de temperatura mais elevada, contribuindo com uma participação de 5 a 20\% no consumo elétrico residencial. É indispensável ainda em processos de manufatura que exijam o controle de umidade, temperatura e pureza do ar, no caso das indústrias farmacêutica e alimentícia, segurança em relação a produtos tóxicos ou inflamáveis, aumento de conforto e produtividade de operários, entre outras aplicações.

As diferenças fundamentais de modelos de condicionadores são quanto aos diferentes tipos de instalação e à tecnologia de compressores utilizados nos ciclos de refrigeração. O compressor é uma das peças mais importantes do ciclo básico de refrigeração, promovendo a circulação do gás refrigerante, cuja função é retirar calor do ambiente condicionado, transferindo-o para o meio exterior através do evaporador.

O funcionamento do compressor alternativo consiste em um pistão movendose alternadamente no interior de um cilindro, com as válvulas de aspiração e descarga dispostas convenientemente para permitir a sucção e a compressão do 
fluido refrigerante. A carcaça do compressor alternativo retém o gás de sucção a baixa pressão; este é trazido para dentro do cilindro do corpo pela ação do pistão e o gás é comprimido e bombeado. Nestes compressores, o conjunto bomba/compressor é isolado da carcaça do compressor, num sistema de suspensão que garante que o compressor esteja assentado no óleo de lubrificação mantendo frio o gás de sucção durante a passagem do corpo até o cilindro. O lado de descarga da bomba e a saída de descarga do compressor são conectados pela serpentina. Um aparelho de ar condicionado tradicional com tecnologia de compressor alternativo requer uma potência elétrica de $1.200 \mathrm{~W}$ para que o ciclo de refrigeração atenda uma carga térmica de 7.500 BTUs.

Já os compressores rotativos são compostos por um sistema no qual a sucção e a compressão do fluido refrigerante ocorrem ao mesmo tempo e de forma contínua, proporcionando melhor desempenho e menor nível de ruído e vibração. Os compressores rotativos possuem menos peças e menor tamanho e peso do que os alternativos, além de um baixo consumo de energia. A redução do consumo energético é resultado de dois fatores principais: a continuidade e a simultaneidade da sucção e da compressão do fluido refrigerante no sistema de bombeamento (tornando a carga aplicada ao eixo da bomba mais uniforme) e a realização do processo de sucção diretamente na câmara de compressão, (evitando que o gás troque calor com os demais componentes internos, o que acarretaria em perdas de rendimento). Um ar condicionado com tecnologia de compressor rotativo requer apenas 720 W para atender a uma carga térmica de 7.500 BTUs, o que, comparado a um ar condicionado utilizando sistema alternativo, equivaleria a $40 \%$ a menos de potência, para uma mesma carga térmica [21]. 
Quanto às instalações, há diferentes classificações, de acordo com o fluido empregado, dentre elas instalações tudo ar, ar-água, tudo-água, ou de expansão direta.

As instalações tudo ar possuem baixo custo inicial, manutenção centralizada e econômica. A regulagem da temperatura ambiente pode ocorrer de diversas formas, sendo que o termostato pode atuar sobre a serpentina de resfriamento, sobre um by-pass da serpentina, ou sobre a serpentina de aquecimento. As instalações podem possuir vazão e temperatura variáveis ou constantes, ou ainda de duplo duto.

As instalações ar-água podem ser em dois, três ou quatro tubos. A primeira delas apresenta a vantagem de separar o controle da temperatura ambiental, com a variação de água quente ou fria, do controle de umidade relativa do local. A instalação a quatro tubos, por sua vez, evita a mistura da água quente e fria das serpentinas no tubo de retorno, evitando assim a perda de energia térmica que ocorre nas instalações a três tubos, dada a mistura de água quente com fria. Há ainda instalações de fan-coils, nas quais as condições ambientais locais são reguladas por um ventilador de velocidade variável e uma serpentina, alimentada com água quente ou fria.

Por fim, as instalações tudo água podem utilizar fan-coils a dois, três, quatro tubos ou de expansão direta. A primeira delas caracteriza-se pela falta de controle da umidade relativa ambiente, da vazão de ar exterior e da temperatura ambiente nas estações intermediárias. Na instalação a três tubos, já é possível aquecer ou esfriar locais independentemente, pois cada fan-coil pode funcionar segundo as necessidades do termostato ambiente. $\mathrm{Na}$ instalação a quatro tubos, o circuito permite evitar perdas por mistura de água quente e fria no retorno comum, que 
ocorrem nas instalações a três tubos, além de apresentarem um menor custo de operação, apesar de um custo inicial mais alto.

Assim, como fatores condicionantes da eficiência energética, além do desempenho do compressor e do tipo de instalação empregada, temos a influência dos fatores climáticos, com a possibilidade de perdas advindas de insolação, temperatura e umidade externa, assim como a carga térmica, ou a quantidade de calor extraído do ar ambiente a fim de mantê-lo em condições desejáveis de temperatura e umidade.

Como alternativa à utilização de energia elétrica, tem-se o ar condicionado a gás natural, que além de aliviar em 99\% a rede elétrica, proporciona diversas vantagens econômicas (como a redução de gastos na operação em valores até 30\%, dada a menor quantidade de equipamentos necessários), ambientais (utilização de água como refrigerante ao invés de refrigerantes sintéticos e do gás CFC) e técnicas (flexibilidade operacional, possibilidade de controle remoto, manutenção simplificada, alta performance mesmo em cargas parciais) [22].

\subsubsection{Aquecimento de Água}

O aquecimento de água é um dos principais usos finais do setor residencial e sua participação na matriz de consumo residencial conta com uma média nacional de $17 \%$, podendo chegar a $30 \%$ em regiões mais frias do país. Aquecedores elétricos funcionam pelo contato da água com resistências. Podem ser de passagem ou possuir reservatórios de acumulação, sendo o primeiro tipo o mais disseminado, por disponibilizar água a qualquer período de demanda apesar das perdas de calor [20]. É representado majoritariamente pelo uso do chuveiro elétrico.

O principal componente do chuveiro é a resistência elétrica, sendo que a maioria dos chuveiros funciona sob tensão elétrica de $220 \mathrm{~V}$ e com duas potências 
diferentes, associadas a duas possibilidades de aquecimento, inverno e verão. A posição inverno corresponde à potência mais elevada e conseqüentemente, a um maior aquecimento. O chuveiro elétrico, do ponto de vista energético, possui uma alta eficiência, com uma alta taxa de conversão de energia elétrica em calor e baixo desperdício, visto que apenas a água a ser imediatamente utilizada é aquecida. Apesar desta alta eficiência, as exigências de conforto de banho por parte dos usuários têm provocado uma elevação nas potências dos chuveiros [23].

A questão da utilização dos chuveiros do ponto de vista das concessionárias de energia elétrica também é de extrema importância, uma vez que o uso do chuveiro elétrico amplia consideravelmente a potência média instalada e a demanda máxima média de habitações populares. Assim, apesar do baixo custo para o usuário final, o uso do chuveiro elétrico representa um elevado investimento para as concessionárias. A participação dos chuveiros na demanda em horário de ponta gira entre 20 e 25\%, ou seja, o baixo fator de carga do equipamento produz uma pequena participação no faturamento das concessionárias, apesar de um elevado investimento associado ao atendimento da demanda máxima.

Pode-se concluir, portanto, que o potencial brasileiro de conservação de energia no aquecimento de água é bastante significativo, e a aplicação em larga escala dos aquecedores solares representa uma opção viável e competitiva para casos de alta demanda de água quente e bons níveis de insolação. Seu funcionamento consiste no bombeamento da água fria até o aquecedor, e posteriormente a um acumulador. Um aquecedor convencional é acionado se a temperatura programada não é atingida [20]. 


\subsubsection{Força Motriz Estacionária}

Os motores constituem a fonte do trabalho produtivo da sociedade industrial moderna, e desempenham papel fundamental na economia, movimentando inúmeros sistemas e equipamentos, desde bombas, compressores e ventiladores a sistemas de aeração e aquecimento. Os motores elétricos consomem aproximadamente dois terços de toda a eletricidade produzida mundialmente. Em âmbito nacional, a força motriz consome acima de $50 \%$ da energia elétrica do setor industrial [24] e cerca de um terço do consumo total de eletricidade.

Motores elétricos podem ser definidos como equipamentos que transformam a energia elétrica em energia mecânica, cujo funcionamento baseia-se no giro de bobinas, orientadas por força magnética, exercida por um campo magnético sobre uma corrente elétrica. Podem ser de corrente contínua e de corrente alternada, subdividindo-se em diferentes tipos de motores: estator de imã permanente e estator por bobina (de corrente contínua), motores monofásicos e trifásicos de indução e síncronos (de corrente alternada).

Os motores síncronos possuem vantagens como a velocidade constante e a possibilidade de ajuste de fase. Entretanto, não apresentam torque de partida, necessitando de motores auxiliares para tanto, além de apresentarem um alto custo de construção e manutenção. Já os motores de indução apresentam um baixo custo de construção e operação, alto torque de partida, freqüências de operação quase constantes e fator de fase variável e próximo de uma plena carga.

A eficiência de um motor está relacionada à quantidade de energia elétrica convertida em energia mecânica. Assim, a energia aproveitada é o resultado da energia elétrica utilizada na entrada do sistema, decrescida das perdas de conversão. Estas perdas podem ser de ordem elétrica, magnética, mecânica e 
térmica, nos diversos componentes do motor, e podem consumir uma quantidade considerável da energia primária recebida.

Além do baixo uso da energia primária, acima de dois terços dos motores operam com carga inferior à nominal, acarretando em rendimentos extremamente baixos. O rendimento de um motor apresenta maiores valores ao operar entre 60 e 90\% de sua potência nominal, e decresce consideravelmente ao acionar cargas que estejam fora desse intervalo. A operação a plena carga em regime permanente também é prejudicial, limitando a vida útil do motor, por conta do aquecimento provocado.

Os motores de alto rendimento representam uma alternativa aos motores de projeto padronizado, ainda que sejam suscetíveis a fatores exógenos como condições de trabalho e método de partida. Entretanto, possuem características positivas no que se refere ao aperfeiçoamento dos componentes utilizados, com alterações no volume, no dimensionamento do motor e na qualidade do material utilizado. Estas medidas, visando a correção de perdas por atrito, histerese, dispersão, ventilação e joule (no rotor e no estator, que respondem por $60 \%$ do total de perdas), podem reduzir entre 20 e $30 \%$ a somatória de perdas, em comparação a motores de projeto padronizado [19].

Como medidas adicionais capazes de aumentar a eficiência de motores podese citar a avaliação das reais condições de carregamento, análise térmica para a avaliação do perfil de elevação de temperatura dos motores, análise do desempenho dos motores em função da tensão aplicada, verificação de desbalanço de tensão e presença de harmônicos, utilização de energia de qualidade satisfatória, compensação do fator de potência, e melhoria das práticas de manutenção, operação e instalação, que contribuem para a redução da eficiência energética. 
Controladores de velocidade desempenham um importante papel no aumento de eficiência dos motores, ajustando a velocidade para o uso requerido de motores de velocidades fixas, reduzindo o desgaste das partes mecânicas e contribuindo para uma economia de energia superior a 50\% em alguns casos. Os inversores de freqüência são dispositivos eletrônicos de variação de velocidade de motores de indução, com os quais o motor não mais trabalha sempre em velocidade e potência nominais, passando a consumir somente a potência requerida pela máquina. A eficiência das instalações equipadas com inversores pode até ser duplicada em muitos casos [20]. Possui aplicação não apenas em motores de indução e de corrente contínua, mas também em acoplamentos hidráulicos e magnéticos.

\subsubsection{Fornos, Caldeiras e Fogões}

Os primeiros usos finais considerados, iluminação, refrigeração, condicionamento ambiental e aquecimento de água a partir do chuveiro elétrico utilizam primordialmente a eletricidade como energético. Já processos utilizando fornos e caldeiras são alimentados por diferentes combustíveis, originados de fontes primárias (como o petróleo e o gás natural) ou secundárias (resultantes de processos de transformação e refino).

Pode-se definir um combustível como uma substância que gera uma reação exotérmica na qual desprende calor e luz ao se combinar quimicamente com outra substância. Este processo termodinâmico, a combustão, é um fenômeno básico para a realização de trabalho nos sistemas termodinâmicos. É essencial para uma série de processos em escala industrial (sendo responsáveis por $53 \%$ do consumo energético deste setor) e domiciliar, como a cocção e o aquecimento de água.

A eficiência da combustão é medida a partir da conversão de um dado combustível em energia térmica útil. A combustão completa não ocorre devido a 
perdas em chaminés e câmaras de combustão, mas os cálculos de eficiência baseiam-se em fatores como a composição do combustível e a energia quimicamente disponível, a temperatura líquida dos gases da chaminé, a quantidade de calor não utilizado e a percentagem de oxigênio consumido pelo combustível.

De forma geral, como medidas capazes de elevar a eficiência do processo, pode-se mencionar o desenvolvimento de projetos visando o máximo de transferência de calor à carga, o aprimoramento da relação custo-efetividade dos processos de aproveitamento de calor rejeitado, o desenvolvimento tecnológico de sistemas de aquecimento, ciclos de combustão e aparelhos que permitam ajustes nos parâmetros operacionais de queimadores em tempo real, entre outras medidas.

\subsubsection{Fornos}

Fornos e caldeiras são os principais equipamentos da indústria que utilizam a energia térmica como fonte de energia. Fornos são destinados ao aquecimento de materiais, com diversos objetivos como cocção, fusão, tratamento térmico, secagem, entre outros. Um forno deve ser capaz de transferir o calor gerado por uma fonte a um material processado, com eficiência, uniformidade e segurança. Para tanto, devem ser considerados, para o seu funcionamento correto, pontos básicos como a absorção do máximo de calor disponível, a transferência de calor da chama para o material, a projeção correta da câmara de combustão a fim de atender a esses objetivos e a qualidade do refratário e do isolamento térmico do forno.

Os fornos a combustão podem ser de quatro tipos principais: fornos em que o combustível e o material estão na mesma câmara (auto-fornos, cubilos), fornos em que o combustível e o material estão em câmaras separadas e os gases de combustão não têm contato com o material (retortas, cadinhos), fornos em que o combustível e o material estão em câmaras separadas, mas os gases de combustão 
têm contato com o material (rotativos, circulares) e, por fim, fornos em que o combustível é constituído pelas impurezas do material ou parte do material, ambos estão em câmaras separadas e os gases de combustão não têm contato com o material (incineradores, conversores).

Os fornos podem ainda ser elétricos, a resistência, a arco voltaico ou de indução. Neste caso, a eliminação de problemas relativos à combustão e a perdas na chaminé elevam consideravelmente a eficiência deste tipo de forno. Fornos a arco voltaico têm emprego na indústria siderúrgica e possuem elevada demanda de energia elétrica. Fornos elétricos de indução, apesar do alto custo, são bastante eficientes, atingindo altas temperaturas em pouco tempo. São utilizados largamente em forjarias e indústrias siderúrgicas e metalúrgicas.

O aumento de rendimento dos fornos (ou a máxima utilização do calor gerado na combustão) está condicionado à utilização correta e à otimização do desempenho de regeneradores, recuperadores e aquecedores de ar. Regeneradores são materiais capazes de absorver gases de combustão, aproveitando parte de seu calor e aumentando, desta forma, o rendimento térmico. Recuperadores separam a corrente de gases quentes da corrente de ar de combustão, normalmente em dois dutos concêntricos. Aquecedores de ar são utilizados em casos nos quais é requerida uma alta temperatura de chama, mas não se dispõe de gases quentes. São utilizados na indústria siderúrgica para o aquecimento do ar destinado a auto-fornos.

\subsubsection{Caldeiras}

Caldeiras ou geradores de vapor produzem e acumulam vapor sob pressão superior à atmosférica a partir de diferentes fontes de energia. Podem ser classificadas em dois grandes grupos: flamotubulares e aquotubulares. 
As caldeiras flamotubulares realizam a combustão dentro da própria caldeira e são caldeiras mais simples, utilizadas inicialmente em navios. Possuem vantagens como facilidade de operação, de limpeza, tratamento de água e manutenção, além de relativo baixo custo. Como desvantagens, possuem partida lenta devido ao grande volume de água, capacidade limitada de pressão e ocupação de muito espaço com relação à área de aquecimento.

As caldeiras aquotubulares, mais modernas, possibilitaram a maior produção de vapor a pressões elevadas e altas temperaturas. Nestas caldeiras, a água circula no interior dos tubos e os gases da combustão circulam por fora. Apresentam vantagens e desvantagens complementares às observadas nas caldeiras aquotubulares. Apresentam facilidade de adaptação de equipamentos, não possuem limite de pressão ou capacidade, além de flexibilidade de operação. Em contrapartida, exigem mão de obra mais qualificada para sua operação, tratamento de água adequado, têm pouca capacidade em relação à demanda dado o volume reduzido de água, e custo mais elevado.

Caldeiras possuem ainda classificações quanto à energia empregada, utilizando combustíveis sólidos (carvão, lenha, bagaço), líquidos (óleos combustíveis) e gasosos (GLP), ou a eletricidade (caldeiras elétricas resistivas e a eletrodos).

A eficiência de caldeiras e fornos está associada à minimização de perdas no sistema. No caso das caldeiras, a perda total de calor é composta pela perda por transferência de calor e pela perda associada aos fluxos que saem da caldeira. Assim, as perdas são representadas em três parcelas: perdas pela chaminé, perdas por convecção e perdas por purgas. Já os fornos possuem perdas por transferência de calor, por vazamentos na estrutura do forno e pelos gases de exaustão. 
A minimização de perdas nestes equipamentos é possível através de diversas medidas práticas de uso racionais. No caso dos fornos, pode-se mencionar a programação da utilização contínua evitando a perda do aquecimento inicial do equipamento, manter portas ou tampas fechadas após o uso e eliminar perdas por frestas, estimar o consumo específico (kWh/unidade de produção) e comparar com os valores típicos para serviços semelhantes, e operar o forno próximo da sua capacidade nominal, posto que o consumo específico aumenta com a redução da carga. Para as caldeiras, como medidas relacionadas ao uso racional e eficiente, pode-se citar: a aferição da temperatura dos gases de escape próximos a valores usuais, a regulagem correta da chama, a possibilidade de aumentar a temperatura da água de alimentação da caldeira e pré-aquecer o ar de combustão (reduzindo o consumo de combustível), a eliminação de vazamentos no sistema de distribuição de vapor e o isolamento de equipamentos e tubulações.

\subsubsection{Fogões}

O uso de fogões para a cocção estende-se a todos os setores de consumo, ainda que esteja concentrado nos setores residencial e comercial. Os principais fins da cocção são a nutrição e o atendimento a padrões de saúde a partir da eliminação de microrganismos e da esterilização de alimentos ou objetos. Estão envolvidos no processo de cocção, todos os fatores capazes de influenciar a combustão e os processos térmicos envolvidos na mesma.

Os fogões são atualmente de diferentes tecnologias, desde fogões a lenha a fogões elétricos, a gás ou utilizando a energia do sol. A qualidade destas fontes energéticas não está limitada a características termodinâmicas, mas também a 
parâmetros ambientais e à possibilidade de controle do processo, administrando assim o consumo de energia na execução de uma dada tarefa.

Os fogões a lenha não promovem a combustão completa dos vapores, provocando poluição com a emissão de monóxido de carbono. O fogão solar apresenta a vantagem de utilizar um energético limpo, mas conta com um processo de baixo controle, uma vez que o funcionamento deste tipo de fogão demanda a radiação solar direta. A cocção por indução magnética é uma tecnologia recente, na qual um componente ferromagnético, como a panela, é aquecido por correntes eletrônicas no próprio material, a partir de um campo eletromagnético variável. Possui elevada eficiência (entre 75 e 85\% contra 45 a 55\% de métodos que utilizam radiação convencional). No entanto o alto custo desta opção tecnológica reduz sua acessibilidade. O fogão elétrico, apesar de já constituir uma tecnologia convencional difundida em países mais desenvolvidos e de apresentar vantagens técnicas como eficiência, controle e segurança, ainda registra entraves em âmbito nacional relacionados a custo e acesso [20].

Como medidas de utilização racional e eficiente de fogões é sugerida a utilização do máximo da capacidade do equipamento, evitando perdas de calor. Recomenda-se também a redução de temperaturas e do preaquecimento. A manutenção adequada, através da limpeza constante e revisões, bem como a utilização de panelas que aumentem a eficiência do processo de cocção, contribuem para o aumento de eficiência energética dos fogões.

\subsubsection{Força Motriz Veicular}

De acordo com o Balanço Energético Nacional de 2005 [25], mais de um quarto da energia consumida nacionalmente é destinada ao setor de transportes. Automóveis, navios, aviões, trens, e outros, fazem uso dos mais variados 
combustíveis, majoritariamente derivados de petróleo, para se movimentarem. A capacidade de transporte é profundamente influenciada pela disponibilidade de energia, desde a utilização de veículos baseados em rodas, embarcações fluviais e marítimas, locomotivas, veículos automotores, aeronaves, submarinos, fazendo uso de diferentes energéticos, como carvão, petróleo, gás natural, eletricidade, energia nuclear, hidrogênio, energia solar ou eólica, entre muitos outros.

A força motriz móvel é constituída, em sua maioria, por motores de combustão interna, que também possuem aplicação industrial no acionamento de máquinas da construção civil, como tratores, carregadeiras, guindastes, compressores de ar, máquinas de mineração, acionamento de sistemas hidrostáticos, entre outros. Tais motores possuem perfis diferenciados quanto a configuração (êmbolo ou rotativos), ciclo (de quatro ou dois tempos), combustível utilizado (Gasolina, diesel, gás natural, GLP, hidrogênio, álcool), configuração da câmara de combustão, ignição (por compressão - ciclo Diesel, ou faísca - ciclo Otto) e método de controle de carga e arrefecimento.

Ainda que possam funcionar a álcool, são movidos basicamente a combustíveis derivados do petróleo, de cujo montante o óleo Diesel representa cerca de metade. Para atender a esta demanda, o Brasil importa cerca de 100 mil barris de Diesel por dia, o que justifica o desenvolvimento de políticas de eficientização energética e racionalização desse combustível. Tais políticas prestam-se igualmente à redução de impactos relacionados ao consumo intenso de energia não-renovável, como a emissão de poluentes causadores de aquecimento global e a geração de material particulado e resíduos tóxicos.

A fim de eficientizar o consumo e melhorar o rendimento de motores, apontase uma série de medidas de desenvolvimento tecnológico. Novos métodos de 
turbocompressão podem contribuir para a redução de consumo de combustíveis, uma vez que estes são capazes de aumentar a potência máxima de um ciclo de combustão, alterando a densidade do ar introduzido no cilindro, mantendo a quantidade de combustível queimado por ciclo e por cilindro. Equipamentos para uma recuperação mais eficiente de calor, sistemas de ignição mais robustos para cargas elevadas em aplicações industriais e desenvolvimento da tecnologia dos geradores permitirão uma taxa mais alta de conversão energética.

Como medidas de uso racional a fim de reduzir o consumo energético veicular, pode-se apontar o funcionamento correto do veículo, desde a utilização correta das marchas e do acelerador, até a pressão de ar correta dos pneus.

\subsection{Ações de GLD}

As medidas ou ações de GLD, para efeito da aplicação do modelo de análise, estão divididas em sete grandes grupos: Controle da Carga; Substituição, Ajuste e Dimensionamento de Equipamentos; Seleção e Substituição de Energéticos e Eficientização de Sistemas de Combustão; Projetos de Edificações Eficientes, Tarifação e Regulação; Armazenamento de Energia e Programas de Informação, Educação e Capacitação.

Estas medidas têm desempenho e potencial condicionados a parâmetros técnicos (como confiabilidade, alcance, magnitude dos resultados, relevância na redução da carga e persistência e durabilidade do programa) ambientais (impactos positivos ou negativos de sua aplicação), sociais e políticos (nível de acordo entre os envolvidos e interessados). Obviamente os parâmetros de avaliação das mesmas são variáveis conforme o setor econômicos abordado (industrial, residencial, comercial ou público). 
Nos próximos sub-ítens segue a descrição de cada grupo de recursos do lado da demanda, em um maior grau de detalhamento e aplicação.

\subsubsection{Controle de Carga}

Este tipo de controle pode ser realizado de diferentes formas. O consumidor pode controlar cargas por meio de equipamentos que restrinjam o tempo de uso ou detectem um nível específico máximo de demanda de determinadas cargas. Tais serviços podem ser ainda solicitados às concessionárias, que o executam por meio de controle remoto de sinal. É possível controlar individualmente, tanto de forma remota quanto no próprio local, equipamentos de pequeno ou grande consumo, além de sistemas de condicionamento ambiental ou aquecimento de água, tanto no setor residencial quanto nos setores comercial e industrial.

Principalmente nos dois últimos setores, é fundamental a escolha das cargas a serem controladas; na indústria devem ser priorizadas cargas de utilidades que não interfiram diretamente no processo de produção. Determinados processos de produção são contínuos, impossibilitando o desligamento das máquinas envolvidas. Em alguns casos, entretanto, é possível atuar em fornos e estufas, que possuem inércia térmica definida e podem ser controlados em função de sua temperatura [60]. Nos ítens seguintes, descrevemos brevemente algumas alternativas de controle de carga para o consumidor final.

\subsubsection{Interruptores Horários (Time Clock)}

Este tipo de controlador desliga um equipamento por um período determinado de tempo (por exemplo, 25\% do tempo de funcionamento, ou 15 minutos por hora), ou até em regimes pré-determinados de rodízio, através de sinais enviados a receptores instalados nas residências ou por meio de micro-motores que comandam 
o relógio e o disco de programação (diário ou semanal). Pode-se ainda pré-agendar horários de desligamento, ou mesmo interromper uma carga, evitando uma sobrecarga do sistema [9].

São largamente utilizados em todos os setores e podem ser aplicados a aquecedores elétricos, painéis e luminosos, balcões frigoríficos, sistemas de condicionamento, entre outros.

\subsubsection{Limitador de Corrente}

O limitador de corrente é capaz de limitar a demanda máxima do consumidor incentivando melhorias diretas no fator de carga. Pode-se sugerir a redução da demanda a determinados níveis em períodos de pico que, ao superados, acionam o limitador de corrente até que a carga seja reduzida. É comumente usado entre pequenos consumidores residencias e estabelecimentos comerciais. Um programa com limitadores de corrente foi desenvolvido pela CEMIG na cidade de Alfenas em 1999 [9].

\subsubsection{Termostatos}

Estes sistemas são usados no controle da demanda, na medida em que são capazes de desligar um dado equipamento, quando ultrapassada uma temperatura máxima definida. Dentre suas aplicações em usos finais, pode-se citar o controle de cargas de ar condicionado controlada por meio de variações graduais de temperatura interna. A partir de determinada temperatura, um relé ativa um controle cíclico no qual o ar condicionado é desligado por alguns minutos por hora. Vale lembrar que o ajuste de temperaturas máximas e mínimas pode ser distinto tanto ao longo do dia, como das épocas do ano [9]. 


\subsubsection{Seletores de Circuito (interlock)}

O sistema de intertravamento ou chaveamento seletivo de circuitos não permite que duas ou mais cargas atuem ao mesmo tempo. Pode ser aplicado nos setores comercial e industrial, para a redução de demanda nas horas de pico. No setor industrial deve-se, contudo, observar o processo de produção associado a tal circuito, posto que determinadas cargas não podem deixar de atuar.

\subsubsection{Controlador de Demanda}

É um dispositivo eletromecânico ou baseado em microprocessadores para a limitação de potência, programável de forma a limitar a demanda a um certo valor, desligando temporariamente certos tipos de carga. O ajustamento máximo desta demanda seria feito pelo consumidor, apoiado numa escala de custos versus nível de demanda. As cargas podem ser desligadas numa seqüência pré-determinada pelo usuário ou ainda pelo sistema de rodízio [10]. Possuem aplicação principalmente entre grandes consumidores, tanto pelo alto custo do equipamento, como pela não aplicabilidade do mesmo no setor residencial, posto que consumidores deste setor têm sua cobrança energética vinculada apenas ao consumo energético.

Os controladores de demanda podem ser do tipo cíclico, evitando a coincidência de demanda de cargas específicas por meio de um timer, ou limitadores de demanda, reduzindo cargas de acordo com uma série prioritária a partir de dados de potência máxima permitida, discriminada por horário [9].

O controlador de demanda pode ser instalado no interior das residências, junto ao aparelho medidor da concessionária. É composto por um disjuntor e um timer, que desvia a entrada do circuito para o disjuntor menor no horário de pico, 
fazendo com que qualquer aparelho de grande potência ligado no horário desarme o disjuntor e desligue o circuito da residência.

No setor industrial, em processos contínuos onde máquinas de produção não podem ser desligadas, deve-se considerar o uso de cargas de utilidades como motores e bombas, ou ventiladores e compressores (dependendo do tipo de indústria), ou do controle adaptativo pertencente a um controlador de demanda inteligente, sem prejuízo para a produção [26].

\subsubsection{Controle de Demanda em Empresas Energéticas}

O GLD não é apenas possível por meio de controle direto de equipamentos de uso final. Há também alguns tipos de controle de equipamentos realizados na própria empresa de energia como a redução da tensão e o controle do fator de potência. No entanto, este tipo de controle pode, em alguns casos, implicar na redução da qualidade de energia fornecida ao consumidor final, prejudicando a empresa provedora de tal serviço.

\subsubsection{Controle Direto de Cargas Residenciais}

Em relação ao Controle Direto de Cargas Residenciais, há uma série de opções relacionadas a interrupção de carga, por controle cíclico. Dentre elas, temos o controle cíclico da utilização de ar condicionado, aquecedores e aquecimento de água, todos de acordo com o princípio da restrição da operação do equipamento. A aplicação prioritária de interrupção de cargas ocorre nos setores residencial e comercial. 


\subsubsection{Substituição, Ajuste e Dimensionamento de Equipamentos}

A substituição de aparelhos e equipamentos elétricos obsoletos e de baixa eficiência por tecnologias novas e eficientes é uma medida de GLD de amplas possibilidades em todos os setores energéticos, sendo capaz de atingir índices de economia de consumo que podem ultrapassar os $30 \%$, de acordo com o Procel. Os principais campos de aplicação desta ação são em iluminação e condicionamento ambiental no setor comercial, aquecimento de água e refrigeração no setor residencial e força motriz no setor industrial. A seguir, são descritas algumas medidas de GLD relacionadas a estes usos finais.

\subsubsection{1. lluminação}

Este uso final é responsável por cerca de $17 \%$ do consumo energético brasileiro e responde por $44 \%$ do consumo do setor comercial e $23 \%$ do consumo residencial [27]. Há diversas possibilidades de emprego de medidas de GLD neste uso final, como a substituição de lâmpadas incandescentes por lâmpadas fluorescentes compactas, circulares ou o uso de tecnologias eficientes de lâmpadas, luminárias e reatores. Pode-se considerar também a adoção de projetos de controle de iluminação, visando eficientizar, principalmente nos setores público e comercial, o uso da iluminação interna e externa.

Diversos empreendimentos envolvendo a substituição de lâmpadas provaramse eficientes em termos de custo/benefício e capazes de alcançar resultados significativos a curto prazo. Como pontos negativos a este tipo de substituição, temos impactos ambientais como a elevação de mercúrio no meio ambiente com o descarte das LFCs, e impactos de ordem técnica como o aumento de distorções harmônicas no sistema. 
As lâmpadas fluorescentes contêm substâncias químicas nocivas ao homem, dentre elas o mercúrio. O descarte das mesmas em aterros, sem descontaminação e cuidados de armazenamento, é capaz de elevar consideravelmente os níveis de mercúrio no meio ambiente. Tal impacto pode ser elevado se considerado o número de lâmpadas descartadas anualmente no Brasil, de 40 milhões, e sentido em locais como aterros, através da contaminação do ar, do solo e das águas subterrâneas [28]. De acordo com dados da FUNASA, a inexistência de procedimentos adequados de reciclagem deste tipo de lâmpadas produz uma quantidade anual de $600 \mathrm{~kg}$ de mercúrio lançado ao ambiente. Uma simulação realizada para uma quantidade média de lâmpadas descartadas entre consumidores que tenham aderido a programas de substituição mostra que a quantidade de mercúrio em locais de deposição de lâmpadas é bastante elevada mesmo para projetos em pequena escala [28].

Ainda como possibilidades de medidas de GLD ligadas à iluminação, houve nos EUA, a substituição de lâmpadas de 150 W utilizadas em semáforos por LEDs de apenas 9W, a um tempo de retorno de 2 anos. O luminoso indicando a saída de veículos de estacionamento, que consome 40W, também pode ser substituído por LEDs de apenas 2W, gerando um potencial de conservação de 1520 MW nos EUA, onde há 40 milhões de placas desse tipo. O departamento de energia norteamericano (DOE) trocou também seu sistema de iluminação com lâmpadas de mercúrio por um sistema a lâmpadas de enxofre, a metade do preço de troca das lâmpadas de mercúrio, economizando $70 \%$ da energia para um fluxo luminoso 4 vezes maior.

Outro fator importante quanto à utilização de lâmpadas fluorescentes é a observação do aumento de distorções harmônicas de tensão e corrente, 
notavelmente superiores em lâmpadas fluorescentes compactas [28]. A utilização obrigatória de reatores, que pode representar uma economia adicional de energia no caso de reatores eletrônicos, pode, por outro lado, implicar em uma menor confiabilidade e produção de ruídos eletromagnéticos devido às freqüências de trabalho na qual operam, reduzindo o fator de potência do conjunto. Tais problemas poderiam apenas serem sanados pelo uso de reatores eletrônicos especiais, com fator de potência próximos a 1,00 e nível de interferência eletromagnética desprezível [28].

\subsubsection{Motores Elétricos}

No setor industrial, entre 50 e $60 \%$ da energia elétrica utilizada é consumida pelos motores elétricos. A fim de aumentar a eficiência energética e reduzir o consumo deste tipo de equipamento, é possível adotar diferentes medidas, tais como o redimensionamento, a substituição de equipamentos, utilizando motores de alto rendimento, a utilização de controle de velocidade, além de, obviamente, operação e manutenção corretas.

Estudos conduzidos na UFRJ, sobre uso eficiente de motores elétricos na indústria [34] diagnosticaram um superdimensionamento dos motores industriais naquele Estado, repercutindo em operações abaixo da faixa ideal de carregamento e quedas consideráveis de rendimento. Como oportunidades de uso mais eficiente de motores, foram sugeridas:

- A substituição de motores padronizados por motores de alto rendimento, cujo interior é constituído de material de melhor qualidade, elevando o seu rendimento em até $10 \%$. O uso de motores de alto rendimento é aconselhável principalmente em processos contínuos, onde o motor opera mais de 7000 
horas por ano. Nos demais casos, é preferível analisar de forma mais criteriosa a viabilidade econômica desta substituição [66]. Segundo o estudo, estimativas mais conservadoras, de um aumento de rendimento de $2 \%$, podem gerar uma economia de 2,4\% de eletricidade, a um custo de energia evitada de $\mathrm{R} \$$ 63/MWh. Se a substituição ocorrer no final da vida útil do motor, os ganhos podem chegar a $3 \%$ e a economia de energia a 2,9\% a um custo de energia evitada de R\$41/MWh [29].

- A eliminação de motores superdimensionados, que acionam cargas com requisição de potência muito abaixo da potência nominal do motor (inferior a 50\%) representaria economias de energia de até 30\% [66]. De acordo com o estudo, a substituição de motores para adequação à carga, com aumento do carregamento em $12 \%$ a um custo $70 \%$ adicional ao preço de motores de alto rendimento geraria um custo de $\mathrm{R} \$ 37 / \mathrm{MWh}$ de energia economizada e uma diminuição do consumo de 2,1\% [29].

- O uso de inversores de freqüência para o controle de velocidade de motores é outra alternativa de alta eficiência, passível de aplicação em processos de controle de variáveis dos processos industriais, principalmente vazão e pressão em sistemas de bombeamento. Controladores de velocidade desempenham um importante papel no aumento de eficiência dos motores, ajustando a velocidade para o uso requerido de motores de velocidades fixas, reduzindo o desgaste das partes mecânicas e contribuindo para uma economia de energia superior a 50\% em alguns casos [30].

As tecnologias de motores com velocidade variável, com motores de indução com rotores e resistores variáveis e motores de indução e inversores de freqüência 
eletrônicos, são eficientes, mas de preço elevado; um controlador inversor de freqüência para um motor de indução de 50 hp custa aproximadamente US\$20 mil, um custo muito superior ao do próprio motor [17].

A economia de eletricidade atingida, de acordo com estudos belgas [30] é estimada em 18\% com um tempo de retorno de até 3 anos, ou de $31 \%$ com um tempo de retorno inferior a 10 anos.

\subsubsection{Refrigeradores}

Posto que o refrigerador elétrico é responsável por aproximadamente um terço do consumo residencial [24], pode-se obter um ganho expressivo em termos de redução de demanda a partir da adoção de equipamentos mais eficientes. Programas de substituição de refrigeradores podem ser conduzidos em parcerias, entre concessionária, fabricante de refrigeradores, lojas e programas de eficiência energética, como no exemplo da Light com o Procel, no qual revendedores e clientes obtiveram benefícios (o consumidor pôde reduzir seu valor de fatura de eletricidade e as lojas obtiveram lucro econômico) [29].

No setor residencial a substituição de refrigeradores antigos por modelos eficientes pode gerar, segundo o Procel, uma economia de eletricidade entre 30 e 40\%. De acordo com um estudo de caso conduzido por Januzzi [32], a substituição de refrigeradores nacionais, num período entre 2005 e 2020, seria capaz de gerar uma economia de $43 \%$ no uso de eletricidade, com um tempo de retorno de 7 anos e uma economia nacional acumulada de 80 TWh.

No caso dos setores comercial e industrial, o emprego de instalações de refrigerações amplia as possibilidades de eficientização energética para medidas como a troca de equipamentos da casa de máquinas, expositores frigoríficos e linhas 
atuais. Pode-se optar pelo uso de sistemas de refrigeração mais compactos e sistemas de sub-resfriamento através de injeção de vapor.

As práticas de controle de capacidade nos compressores (para evitar picos de partida) e controladores de velocidade variável (para controle dos ventiladores dos condensadores) são algumas das opções aplicáveis a sistemas de refrigeração. Estas podem gerar uma eficiência de 15\% em média, de acordo com o tipo do sistema, condições de trabalho e manutenção dos equipamentos. A utilização de controladores de velocidade na refrigeração da indústria de alimentos pode gerar economias energéticas superiores a 50\% [33].

Na refrigeração industrial, a reforma de plantas industriais, a fim de evitar a sobrecarga da capacidade de refrigeração de produtos armazenados consiste em uma medida extremamente eficaz de eficiência energética. A ampliação do centro de estocagem ou a transferência deste excedente para novas áreas frigorificadas e o conseqüente aumento da potência frigorífica representam benefícios consideráveis para o usuário através da não elevação do consumo energético e o não rompimento de contratos de demanda acordados com as distribuidoras de energia. A aplicação de alguns componentes, como o sistema de arrefecimento do compressor, pode ainda otimizar o sistema industrial, na medida em que colabora à não elevação do consumo energético, ao aumento de segurança do circuito (por evitar situações extremas de vazamento) e à manutenção do controle da temperatura de descarga do compressor.

\subsubsection{Utilização de Ar Condicionado de Alta Eficiência}

Os aparelhos de ar condicionado respondem por cerca de 20 por cento do uso de eletricidade do setor comercial. Esta fração, contudo, aumenta para o caso 
de grandes edifícios comerciais, hotéis, ou shopping centers, onde pode superar metade do uso total de eletricidade. De acordo com a Eletrobrás [19], calcula-se que aparelhos de ar condicionado de potência entre 1 e 2 kW gastem entre 240 e 500 kWh por mês. Posto que a maior parte dos condicionadores tem mais de dez anos de fabricação, e portanto possuem eficiência inferior, pode-se atingir uma redução de consumo superior a $30 \%$ com a substituição dos mesmos por sistemas mais modernos de condicionamento [19].

No caso do setor industrial, grande parte das instalações de ventilação e ar condicionado é superdimensionada, pois são calculadas para condições ambientais extremas. Assim, há inúmeras oportunidades de economizar energia em sistemas de ventilação e ar condicionado, como verificar a possibilidade de elevar os níveis de temperatura utilizados nos ambientes servidos pelo ar condicionado; procurar operar compressores e chillers a plena carga em vez de dois ou mais com carga parcial; reduzir o fluxo de ar para todas as áreas ao nível mínimo aceitável; verificar perdas e operações irregulares do compressor.

\subsubsection{Seleção e Substituição de Energéticos e Eficientização de Sistemas de Combustão}

Este grupo de medidas de eficientização energética não está voltado apenas para a energia elétrica, e sim para o uso eficiente de combustíveis, a seleção de energéticos (dentro de critérios técnicos e ambientais) e a utilização de energéticos em alternativa à rede elétrica.

\subsubsection{Seleção e Substituição de Energéticos}

A seleção de combustíveis para sistemas de combustão, tanto em motores estacionários como em motores de uso veicular, pode resultar em benefícios de 
ordem econômica (no caso da seleção de um combustível de custo inferior ao combustível vigente) e principalmente ambiental (ao se optar por um combustível com um menor nível de emissões atmosféricas). A substituição de combustíveis fósseis como o diesel e a gasolina por combustíveis mais favoráveis do ponto de vista ambiental como o gás natural, o álcool e o biodiesel, apesar de não implicar necessariamente em redução energética, resulta em benefícios principalmente ambientais, possibilitando inclusive a geração de certificados de créditos de carbono.

\subsubsection{Utilização de Energéticos em Alternativa à Rede Elétrica}

A utilização de gás natural ou outros energéticos em substituição à rede elétrica para usos finais de condicionamento ambiental também pode render bons índices de eficiência além do recorte da carga de demanda em períodos de pico. O uso de Gás Liquefeito de Petróleo tem diversas aplicações, essencialmente nos setores residencial e comercial.

A seleção e substituição de energéticos pode ser efetuada tanto no setor de transportes, quanto em aplicações residenciais, comerciais e industriais relacionadas a cocção, aquecimento de água ou condicionamento ambiental, rendendo potenciais benefícios de ordem técnico-econômica (reduções tarifárias alívio do sistema em horários de sobrecarga), políticas (uso preferencial de combustíveis produzidos nacionalmente, de risco cambial inferior) e sociais (desenvolvimento de localidades isoladas do sistema e criação de empregos a partir da promoção de novas fontes).

\subsubsection{Aquecimento de Água por Coletores Solares}

A substituição da eletricidade pela energia solar, em aplicações para aquecimento de água, permite retirar a demanda devida ao uso de chuveiro elétrico de um consumidor residencial, usualmente no período da ponta do sistema elétrico. 
Seu campo de aplicação vai desde o fornecimento de água quente para o uso doméstico, aquecimento de piscinas, podendo ser utilizados inclusive em aplicações de climatização e refrigeração de alimentos [34]. O uso de coletores solares, dispositivos tecnologicamente simples, pode ser aplicável a localidades com pequena demanda de energia a custos médios de investimento, com tempos de retorno entre 5 e 7 anos.

Posto que o consumo de eletricidade destinado ao uso final de aquecimento pode até ultrapassar $20 \%$ do consumo total residencial, tem-se na utilização do aquecimento solar de água para banho uma importante medida de GLD. Projetos do PROCEL desenvolvidos em 100 unidades habitacionais de Betim, Minas Gerais em parceria com a Caixa Econômica Federal, obtiveram resultados positivos de redução da conta de luz em 40\% por conta da substituição do chuveiro elétrico [34].

\subsubsection{Eficientização de Sistemas de Combustão}

A eficientização de sistemas de combustão, em diferentes modalidades como o uso eficiente de combustíveis no setor veicular, de motores no setor industrial e de fogões no setor residencial é promovida pelo CONPET (Programa Nacional de Racionalização do Uso dos Derivados do Petróleo e do Gás Natural). O CONPET pretende obter um ganho de eficiência de $25 \%$ no uso de derivados de petróleo e gás natural nos próximos 20 anos, sem afetar o nível de atividade dos setores econômicos [12].

Em relação ao setor de transportes, há o projeto EconomizAR, que fornece apoio técnico gratuito ao aprimoramento da gestão do uso de combustíveis e lubrificantes, quanto à qualidade, estocagem, consumo e nível de emissões do combustível utilizado em ônibus e caminhões. Há ainda um projeto da Petrobrás, de 
ônibus a Gás Natural no Rio de Janeiro, transportando mais de 90 mil passageiros por mês.

Quanto ao setor residencial, a etiquetagem de fogões e aquecedores a gás visa estimular o aumento de eficiência na utilização de aparelhos domésticos a gás. Tal programa conta com a participação dos fabricantes representados pela Associação Brasileira de Indústria Elétrica e Eletrônica e pela Associação Nacional de Fabricantes de Produtos Eletroeletrônicos.

Em relação a fornos e caldeiras, amplamente usados no setor industrial, é possível aumentar sua eficiência por meio da otimização de processos, calor utilizado, controle da velocidade e utilização de componentes mais eficientes, conforme comentado no item 4.2.6.

\subsubsection{Projetos Eficientes de Edificações}

Projetos eficientes de edificações visam aproveitar ao máximo recursos naturais como luz, ventilação, materiais adequados a cada região, economizando, desta forma, energia gasta com iluminação e condicionamento ambiental, usos finais responsáveis por grande parte dos consumos residenciais e comerciais, além dos consumos públicos e industriais.

Edifícios devem considerar a orientação de aberturas e janelas a fim de aproveitar melhor a incidência da luz e a ventilação. Por meio de artefatos construtivos pode-se impedir a penetração direta de raios solares (que aquecem o ambiente, sobrecarregando o sistema de ar condicionado), aproveitando, porém, sua luminosidade. Podem ser criadas entradas de luz natural pela cobertura da edificação através de elementos construtivos como clarabóias ou coberturas de 
vidro, reduzindo a necessidade do uso de luz artificial e utilizando sensores que regulam a capacidade das luzes vinculadas à intensidade da luminosidade natural.

Projetos de edificações comerciais tais como hospitais, restaurantes e aeroportos podem buscar um melhor aproveitamento da iluminação natural através de soluções eficientes de arquitetura bioclimática, evitando o consumo energético convencional referente à iluminação. Tais ambientes não raro demandam a utilização de iluminação artificial durante todo o período comercial. Em projetos de arquitetura bioclimática, são sugeridas entradas superiores e laterais de luz natural como forma de suprir parte considerável da iluminação interna durante o dia. A luz artificial é então utilizada de forma complementar à iluminação natural, quando necessário.

Há ainda projetos que contemplam um melhor aproveitamento da água e da energia utilizada internamente, além da monitoração e o controle de equipamentos com a utilização de CLPs. Projetos conduzidos pela COPPE e pelo Centro de Análise de Sistemas Alternativos de Energia, da Universidade Estadual do Oeste do Paraná, alcançaram economias de energia de até 60\%, com custos de implantação de $5 \%$ acima da média [34].

As residências utilizadas nos projetos contavam com desenhos inovadores com modernas tecnologias, obtendo o melhor aproveitamento tanto da ventilação quanto da insolação disponíveis, bom isolamento térmico, possibilidade de armazenamento da água da chuva e iluminação suplementar de luz natural através de aberturas zenitais. Projetos de maior escala podem ser empregados nos setores comercial (hotéis e hospitais), industrial e público, voltados para uma maior eficiência de sistemas de iluminação, bombeamento e condicionamento ambiental e isolamento térmico. 
No caso da região de estudo, Araçatuba, de iluminação solar abundante, edificações residenciais e comerciais podem beneficiar-se de medidas bioclimáticas, reduzindo o consumo de usos finais como a iluminação.

\subsubsection{Tarifação e Regulação}

A tarifação é um elemento essencial para o sucesso de programas de GLD, tanto como medida isolada de controle de demanda, quanto implementada em conjunto com outras ações, como a substituição de equipamentos ou o armazenamento de energia. As tarifas, a partir de seu sinal econômico, são um fator essencial na motivação dos consumidores em relação à adoção de programas de GLD, pois os incentivam a ter um maior controle sobre seu consumo e conseqüente gasto mensal em energia elétrica. A tarifação, com o modelo antigo de empresas verticalizadas, trazia benefícios à concessionária, como a redução do custo marginal da energia com a postergação de investimentos de ampliação da oferta, a retenção de carga e a promoção da empresa, ao oferecer alternativas de uso racional e eficiente da energia [10]. No atual contexto de mercado, pode-se considerar a tarifação como um instrumento de controle de demanda e redução de gastos energéticos por parte de grandes consumidores.

A partir da regulação, temos alguns pontos principais relativos à problemática da composição de tarifas, que devem ser equilibrados de modo a satisfazer as necessidades e interesses dos envolvidos na questão energética, sejam eles empreendedores, empresários ou consumidores. Estes pontos a serem alcançados são a minimização do custo da eletricidade ao consumidor, a preservação da viabilidade econômica das concessionárias e, evidentemente, a abordagem de questões de ordem sócio-ambiental. 
Dentre os principais tipos de tarifas visando o GLD pelo lado do consumidor, podemos citar tarifas de interrupção, tarifas variáveis no tempo, tarifação em tempo real e tarifas para blocos de consumo, descritas nos próximos sub-ítens.

\subsubsection{Tarifas de interrupção}

As tarifas de interrupção são um modo de vender energia sem vender capacidade. Utilizada majoritariamente no setor industrial, possibilita que o consumidor opte por um decréscimo de confiabilidade em troca da cobrança reduzida de demanda. São oferecidos créditos aos consumidores caso eles permitam que o suprimento de energia elétrica seja interrompido após um período especificado de tempo avisado pela concessionária. A freqüência de interrupções, a duração e o volume de kilowatts de carga por interrupção podem ser escolhidos, e o crédito é calculado para cada variação de condição.

\subsubsection{Tarifas variáveis no tempo}

Conhecidas em inglês como time-of-use (TOU), são uma forma de precificação diferenciada de energia e demanda, refletindo variações nos custos de produção da empresa concessionária, que podem ocorrer de acordo com estações, períodos do ano, ou inclusive do dia. Medidores especiais são instalados para detectar o consumo durante horários de pico, intermediários e fora de pico [35]. Um exemplo simplificado desta tarifa é a horosazonal, que varia segundo a hora do dia e a estação. Tarifas diferenciadas ao longo do tempo são essencialmente aplicadas para mudar a demanda e o consumo, através de um sinal de preço fixado para cada período, de forma a informar com antecedência o perfil de consumo ao consumidor final. 


\subsubsection{Tarifação em tempo real}

Esta tarifa é utilizada especialmente para emprego comercial e industrial, no intuito de reduzir ou transferir cargas. Sistemas avançados de comunicação permitem ao consumidor observar o uso da energia em tempo real e preços futuros (preços horários do dia seguinte, por exemplo), possibilitando decisões acerca de ajustes de operação conforme o preço de tarifas. A tarifa pode ser fixada a uma linha de base (condicionada a histórico de uso ou alterações de operação ou clima), a partir da qual o consumidor paga ou recebe um adicional conforme o uso. Outro tipo de tarifa pode conectar o uso a preços váriaveis a cada hora, sem estimativas de linha de base [35].

Valores para períodos de ponta ou fora de ponta são estimados proximamente ao consumo, e não pré-especificados com antecedência. Tal estratégia é justificada por pressões de custos, desafios competitivos, e incertezas do planejamento.

Neste tipo de tarifação, o controle de carga pode estar diretamente vinculado ao preço de energia em cada instante, oferecendo inclusive a possibilidade de se utilizar energia proveniente de diferentes combustíveis, selecionados conforme o custo no instante avaliado.

\subsubsection{Tarifas para blocos de consumo}

Este tipo de tarifação, ainda que não possua diferenciação de acordo com a hora do dia e tampouco detecte reduções de pico, proporciona uma série de incentivos relativos ao consumo doméstico. Pode ser de tipo crescente ou decrescente. Tarifas crescentes elevam o custo do consumo marginal de energia 
para consumidores de grandes volumes, incentivando a redução do consumo marginal doméstico e beneficiando consumidores de baixa renda e baixo consumo (ainda que baixo consumo não possua necessariamente conexão direta com baixa renda). Já tarifas decrescentes provocam o efeito contrário, fomentando um maior consumo por parte de pequenos consumidores e aumentando a carga em horário de pico. Tais conseqüências dependem, porém, da estrutura exata da tarifa e da variação de preço da energia. Variando preços e o número de blocos, é possível criar diversas tarifas desta modalidade, atendendo a diferentes objetivos, sejam eles de GLD ou metas específicas de empresas concessionárias.

É importante acrescentar que os programas tarifários descritos podem ter suas chances de adoção variadas de forma considerável a partir da inclusão de incentivos tarifários diretos ou implícitos, visando um bom índice de adoção. Tais incentivos são contemplados principalmente na dimensão econômica da avaliação e podem ser de diversos tipos, como: empréstimos ou pagamentos diretos a consumidores, reduções na fatura de energia, devoluções, minimização de investimentos iniciais do consumidor na aquisição de tecnologias de GLD, subsídios na instalação de equipamentos de controle de demanda, entre outros.

\subsubsection{Tarifa Horosazonal Alternativa}

Segundo Januzzi [36], no caso de consumidores industriais, uma opção de tarifa horosazonal alternativa viável seria a combinação de um novo posto tarifário na madrugada, período considerado de carga leve para o sistema da concessionária, de baixo custo de demanda e aplicação zonal e setorial (para segmentos da economia com melhor potencial de modulação para este período). A eventual mudança do critério de classificação dos consumidores, de nível de tensão 
para nível de potência, como ocorreu na França, e seus possíveis impactos nas tarifas horosazonais é outra possibilidade a ser explorada [36].

Durante o período de racionamento de energia, a CELPA realizou uma experiência em estudo de tarifa diferenciada no Pará, com o objetivo de antecipar o mercado de uso de eletrodomésticos durante a madrugada. Foi proposta a Tarifa da Madrugada, de 00:00 as 7:00, com um desconto de 15\% sobre a tarifa convencional neste horário. A opção era limitada a consumidores cujo consumo fosse superior a $1000 \mathrm{kWh} /$ mês e tinha o objetivo de antecipar o mercado de ar condicionado. Os resultados da simulação indicaram um consumo médio de $73 \%$ durante o dia e de $27 \%$ de madrugada, representando um desconto final na fatura de $4 \%$ [36].

\subsubsection{Armazenamento de Energia}

Uma das técnicas de gerenciamento de carga, mais especificamente de preenchimento de vale é a possibilidade de se armazenar energia sob a forma de calor ou frio, por meio de equipamentos, para utilização em períodos de pico. Este calor ou frio é produzido em períodos de baixo consumo de energia (fora do horário comercial ou de ponta), aliviando o sistema nas horas de pico e dispensando uma contratação adicional de demanda. Esta técnica é de especial interesse em ações de alteração da curva de carga e deslocamento de pico.

É importante ressaltar, porém, que tal medida não visa exatamente a economia de energia, e sim um ganho econômico a partir do uso do equipamento refrigerador em horários onde a tarifa apresenta valores mais baixos.

Como modalidades de armazenamento de energia, pode-se citar o armazenamento de calor, de água aquecida e de frio, descritos nos próximos ítens. 


\subsubsection{Armazenamento de Calor}

O armazenamento de calor pode ser feito através de reservatórios subterrâneos isolados, construídos com materiais isoladores de calor como cerâmicas. Outra possibilidade, para casas térreas, fazendas e pequenos edifícios, é o uso de materiais que funcionam como meios de armazenamento de calor proveniente de energia solar. Neste caso os materiais mais indicados, a custos modestos de sistema total e manutenção, são pedras, misturas líquidas anticongelantes, sal de Glauber e pirofosfato de sódio.

Estes dois últimos fazem parte dos PCMs (phase change materials ou materiais que mudam de fase) substâncias químicas que passam por uma transição de sólido-líquido a temperaturas dentro de limites desejados, para propósitos de aquecimento. Durante o processo de transição o material absorve energia ao passar de estado sólido para líquido e libera energia ao voltar para sólido. O que torna este tipo de material interessante para o armazenamento de calor é sua alta capacidade de guardar uma grande quantidade de energia a uma mesma temperatura. $O$ sal de Glauber pode ser usado em residências para armazenar calor produzido em horários fora de pico; o sal é liquefeito através do calor durante a noite e se congela liberando calor durante o dia [37].

O volume do material de armazenamento usado depende basicamente de alguns fatores básicos, entre eles a quantidade de calor necessária para manter uma área aquecida, a quantidade de calor de reserva desejada (em se tratando de energia solar, caso a energia não possa ser coletada por um certo número de dias) e o tipo de material usado. 


\subsubsection{Armazenamento de água aquecida}

O aquecimento de água é realizado em horários fora de pico, com operação habitual da parte elétrica, que tem sua operação reduzida em horários de pico. A unidade de armazenamento deve, obviamente, estar dimensionada para satisfazer a perdas e à demanda de água quente enquanto a mesma não estiver sendo gerada. Pode ser operada pela concessionária, com tarifas especiais, ou pelo próprio consumidor, através de temporizadores e, logicamente, de uma mudança de hábitos no uso de equipamentos que demandem água aquecida.

\subsubsection{Acumulação de Frio}

A termoacumulação, ou armazenamento de frio, consiste no armazenamento, em um meio de alto calor latente, de gelo ou água resfriada produzidos por equipamentos resfriadores (como chillers), em períodos fora de ponta. Os chillers são resfriadores de líquidos, próprios para uso em sistemas centrais de grande porte, tanto no setor comercial, em hospitais, shopping centers, hotéis, supermercados, entre outros, como em indústrias e processos industriais.

O frio armazenado auxilia no resfriamento do ar condicionado durante o dia, nos horários de ponta de carga. O armazenamento de gelo difere do armazenamento de água gelada pela densidade de energia armazenada, cerca de 7 vezes superior no primeiro caso, por conta do calor latente de fusão. É utilizado comercialmente desde a metade do século passado, em ambientes que requerem refrigeração em porções limitadas do dia. Nos últimos tempos, vem recebendo interesse por parte de consumidores de eletricidade, como maneira segura e econômica de redução de custos operacionais.

Um exemplo de aplicação desta tecnologia pode ser a utilização de termoacumuladores para a produção e armazenamento de gelo em períodos fora da 
ponta, utilizados em sistemas de ar condicionado. Os termoacumuladores são equipamentos com elevada capacidade de armazenamento de energia como calor latente, a baixas temperaturas. São constituídos por subsistemas de refrigeração, fluido de transporte e componentes de controle. A energia é armazenada no material de mudança de fase que, para o banco de gelo, é a água. A transferência da energia do material de fase é obtida com a circulação de um fluido de trabalho. Durante o período de carga do acumulador, é utilizado o circuito de refrigeração.

Tal aplicação é bastante eficiente principalmente no setor comercial, onde a demanda energética referente ao condicionamento ambiental é bastante elevada. $\mathrm{Na}$ região de Araçatuba, a termoacumulação pode proporcionar um bom deslocamento de carga do consumo elétrico dado o uso considerável do ar condicionado frente a altas médias de temperatura.

Considerando ainda que a maioria de sistemas de condicionamento ambiental está dimensionada para condições máximas de operação em períodos comerciais, a possibilidade de se acumular frio permite a redução da potência e demanda elétrica máxima a uma mesma taxa de consumo de energia.

É possível escolher entre armazenagem parcial ou total. A primeira delas desloca toda a carga, transferindo-a para horários fora de ponta, e é comumente usada em ampliações de instalações existentes, utilizando-se para tanto a capacidade de um chiller disponível. Já para instalações novas, o armazenamento parcial é uma possibilidade mais prática e de maior eficiência de custos. Neste método o chiller funciona continuamente, formando gelo durante a noite e refrigerando diretamente durante o dia, com a ajuda do frio armazenado. O aumento das horas de operação pode reduzir consideravelmente a capacidade do chiller, uma vez que a carga média também é reduzida [19]. 

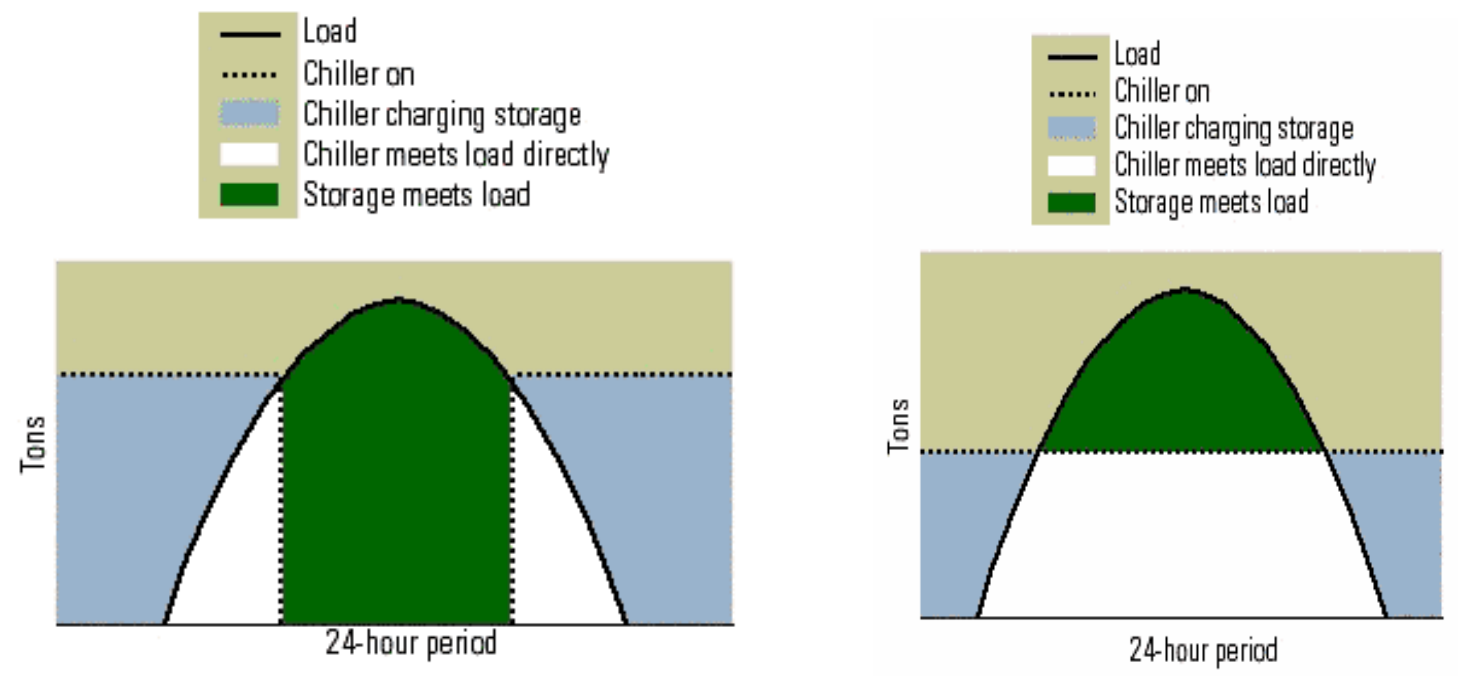

Figura 4.3.6.3: Curvas de Carga para Armazenagem Parcial e Total

Fonte: BC Hydro, 2004

\subsubsection{Programas de Informação, Educação e Capacitação}

Os objetivos de programas de educação ou campanhas educativas são de aumentar a consciência da sociedade em geral, quanto ao uso racional de energia e ações de eficiência energética. Como possibilidades de programas informativos podemos citar campanhas públicas de combate ao desperdício de energia e divulgação de material informativo sobre a conscientização de hábitos de consumo. Em relação a programas educativos podemos considerar parcerias com prefeituras, estados ou governo federal, para tornar obrigatória nas escolas de nível fundamental e médio a realização de palestras ou mesmo cursos regulares sobre conservação de energia, com a disponibilização de material pedagógico apropriado. Para instituições de ensino superior, é possível incorporar disciplinas fixas de conservação e uso eficiente de energia em cursos de engenharia, como vem realizando o Procel [24]. Nos setores comerciais e industriais, pode-se realizar seminários internos em empresas, dirigidos à redução do desperdício de energia. É importante ressaltar ainda a necessidade de se capacitar profissionais e professores na área de 
eficiência energética, para a constituição de um corpo docente habilitado a conduzir tais programas educativos.

Estes programas demandam uma realimentação constante em intervalos regulares de tempo buscando a reafirmação de objetivos desejados, posto que a obtenção de tais resultados depende diretamente de fatores humanos suscetíveis (psicológicos e comportamentais) e de caráter inexato. Assim, a mensuração de resultados obtidos, quando possível, é sujeita a consideráveis margens de erro. De qualquer forma, programas realizados pelo PROCEL através da CEMIG, COPEL E CEE em escolas de nível fundamental a médio, foram capazes de alcançar uma economia acumulada de 950.000 MWh entre os anos de 90 e 2003, dos quais 250.000 foram obtidos no último ano (o programa abrangeu cerca de 2 milhões de alunos nesse período, indicando uma economia anual obtida de $84 \mathrm{kWh}$ por aluno) [24].

A etiquetagem de equipamentos elétricos diversos, desde eletrodomésticos a fogões e aquecedores, bem como a atribuição de selos de eficiência energética, apesar de constituir uma ferramenta fundamental na informação e difusão de equipamentos eficientes, fica, neste modelo de análise de recursos energéticos do lado da demanda, incluída como um atributo técnico capaz de promover a substituição de equipamentos, uma das medidas apontadas de GLD. Assim, esta modalidade de informação e propaganda constitui mais um adicional e impulsionador a recursos do lado da demanda do que um recurso propriamente dito.

\subsection{Setores de Consumo}

Uma vez levantados os usos finais e apontadas suas possibilidade quanto a eficientização energética e gerenciamento da demanda, os setores de consumo ou 
setores econômicos aos quais ações ou medidas são aplicadas, constituirão o terceiro componente de um recurso energético do lado da demanda.

Posto que os perfis de consumo energético de cada setor são de características bastante particulares, pode-se considerar a escolha do setor de aplicação como uma etapa de extrema importância para a utilização de recursos do lado da demanda e para o modelo de caracterização como um todo. Isto porque nesta etapa, com o direcionamento dos usos finais para determinados tipos de atividade, sejam elas comerciais, industriais ou de outro tipo, ocorre a primeira seleção de recursos aptos de aplicação em um dado planejamento.

O mercado de energia elétrica é dividido em nove classes de consumo, definidas por instrumento legal, porém de característica comercial. Estas classes são: residencial, industrial, comércio e serviços, rural, iluminação pública, poder público, serviços públicos (subdivididos em água, esgoto e saneamento, tração elétrica); próprio (detalhado interno, próprio e canteiro de obras).

Na Figura 4.4.1. abaixo, é ilustrada a ramificação dos principais setores de consumo de eletricidade, subdivididos em categorias e estratos de consumo.

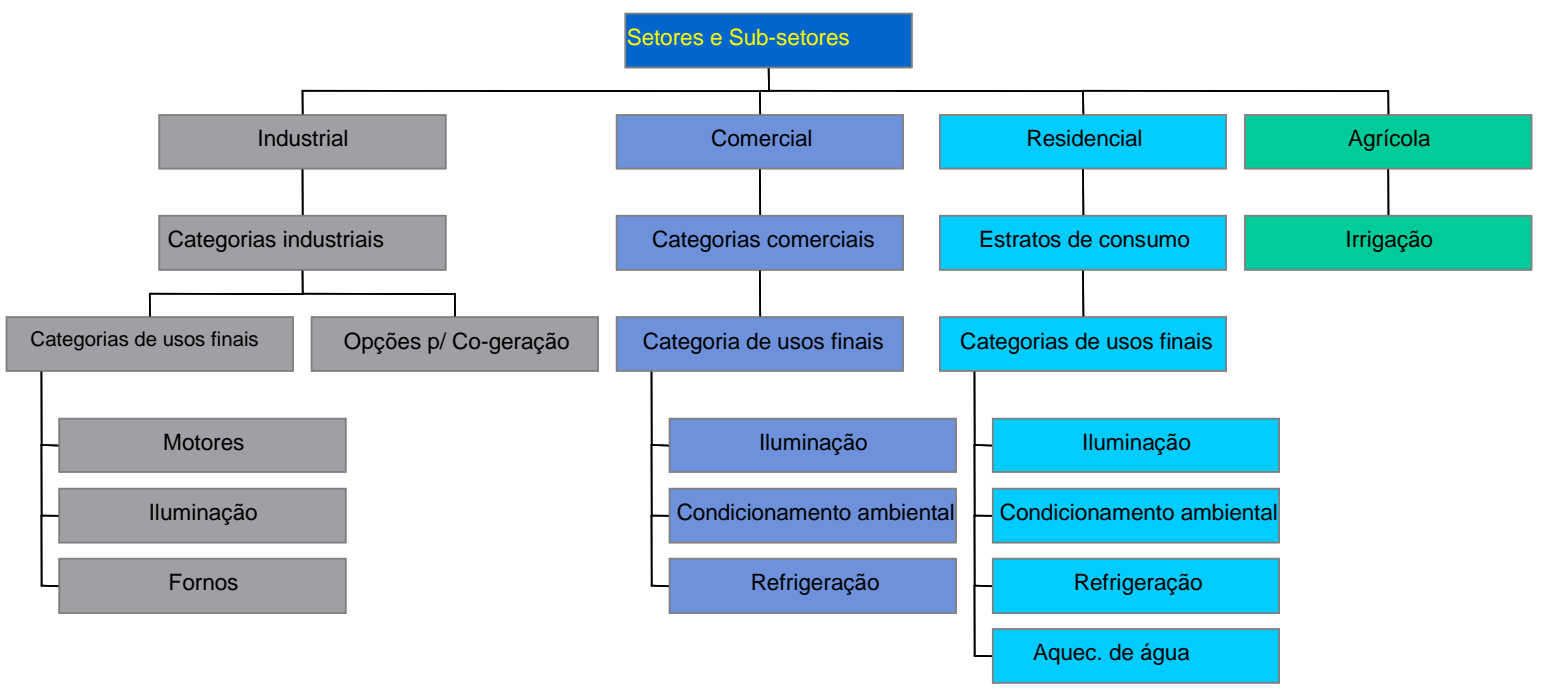

Figura 4.4.1: Setorização do Consumo de Eletricidade. Fonte: [Sauer, 2005]. 
O consumo residencial é resultado do produto do número de consumidores residenciais pelo consumo per capita, variável conforme a renda domiciliar, os hábitos de consumo de cada residência, a projeção da taxa de atendimento (relação entre o número de consumidores residenciais e o número total de domicílios) e os níveis crescentes de saturação do consumo previsto (através do crescimento esperado da renda e da capacidade de uso de eletrodomésticos mais intensivos em energia elétrica) [1].

O consumo industrial depende diretamente do perfil das cargas nas principais indústrias, como a siderúrgica, a metalúrgica, a química, entre outras. O comportamento do mercado industrial de energia elétrica pode ser relacionado a medidas de maior impacto no mercado, tais como a instalação de grandes cargas industriais, e expectativas de mudanças de tarifa e programas de racionalização. $\mathrm{O}$ consumo industrial regional é função de informações das grandes cargas da área focada.

O consumo industrial das concessionárias de uma dada região é resultado do consumo industrial total por região decrescido do consumo de auto-produtores e, ao analisar a evolução histórica da participação industrial de cada região (através do percentual do total de energia elétrica industrial vendido pelas concessionárias), incorpora em sua elaboração elementos como os efeitos multiplicadores de investimentos das grandes cargas industriais, perspectivas de evolução de parâmetros como recursos naturais e renda da população [1].

O consumo das classes comercial e serviços, poder público, iluminação publica e água, esgoto e saneamento é correlacionado ao consumo residencial. A classe comercial, porém, tem um porte diferenciado de cargas, comprometendo a relação. As classes de poder e iluminação pública têm seu consumo guiado por 
tendências históricas e expansão de serviços de concessionárias. A classe de água, esgoto e saneamento depende da avaliação dos sistemas de abastecimento de água e das instalações de compressão e tratamento de esgoto, além, obviamente, do consumo residencial e do número de consumidores residenciais [1].

O consumo rural é definido a partir da tendência histórica junto com programas de eletrificação rural mantidos por concessionárias, cooperativas, órgãos municipais, órgãos regionais, órgãos federais e estaduais. É também obtido pelo produto do consumo médio rural pelo número de ligações no campo. Por outro lado, o consumo em tração elétrica é determinado pela projeção a partir da evolução verificada desse serviço, acompanhada dos programas de instalação e expansão referentes especificamente à tração elétrica [1].

O consumo próprio em escritórios, oficinas e outras instalações refere-se à energia consumida pela concessionária, mantendo-se geralmente em uma participação aproximadamente constante com respeito ao seu mercado. Já a projeção do consumo de canteiros de obras é determinada a partir da programação de obras das concessionárias [1].

Nas figuras 4.4.2 e 4.4.3 a seguir, temos a composição setorial do consumo de eletricidade e energia, informação de extrema importância para o direcionamento das medidas de GLD adotadas, uma vez escolhido o setor de consumo a ser analisado. Os setores de consumo de eletricidade de maior destaque são, de acordo com dados do BEN 2005 [25], o industrial (47,9\%), o residencial $(21,9 \%)$ e o comercial (13,9\%). Juntos, estes três segmentos representam cerca de $84 \%$ do consumo total de eletricidade, deixando $16 \%$ para os demais setores como o agropecuário, o público e o energético. 
Quanto ao uso da energia, o setor industrial é novamente o maior consumidor, com cerca de $38 \%$ do consumo total, seguido pelo setor de transportes, que representa quase $27 \%$ do consumo total de energia, e o setor residencial, contabilizando cerca de $12 \%$ do consumo final.

Desta forma, nos ítens seguintes serão descritos os segmentos industrial, residencial e comercial, de maior representatividade quanto ao uso da energia elétrica e aplicação no modelo de caracterização de recursos.

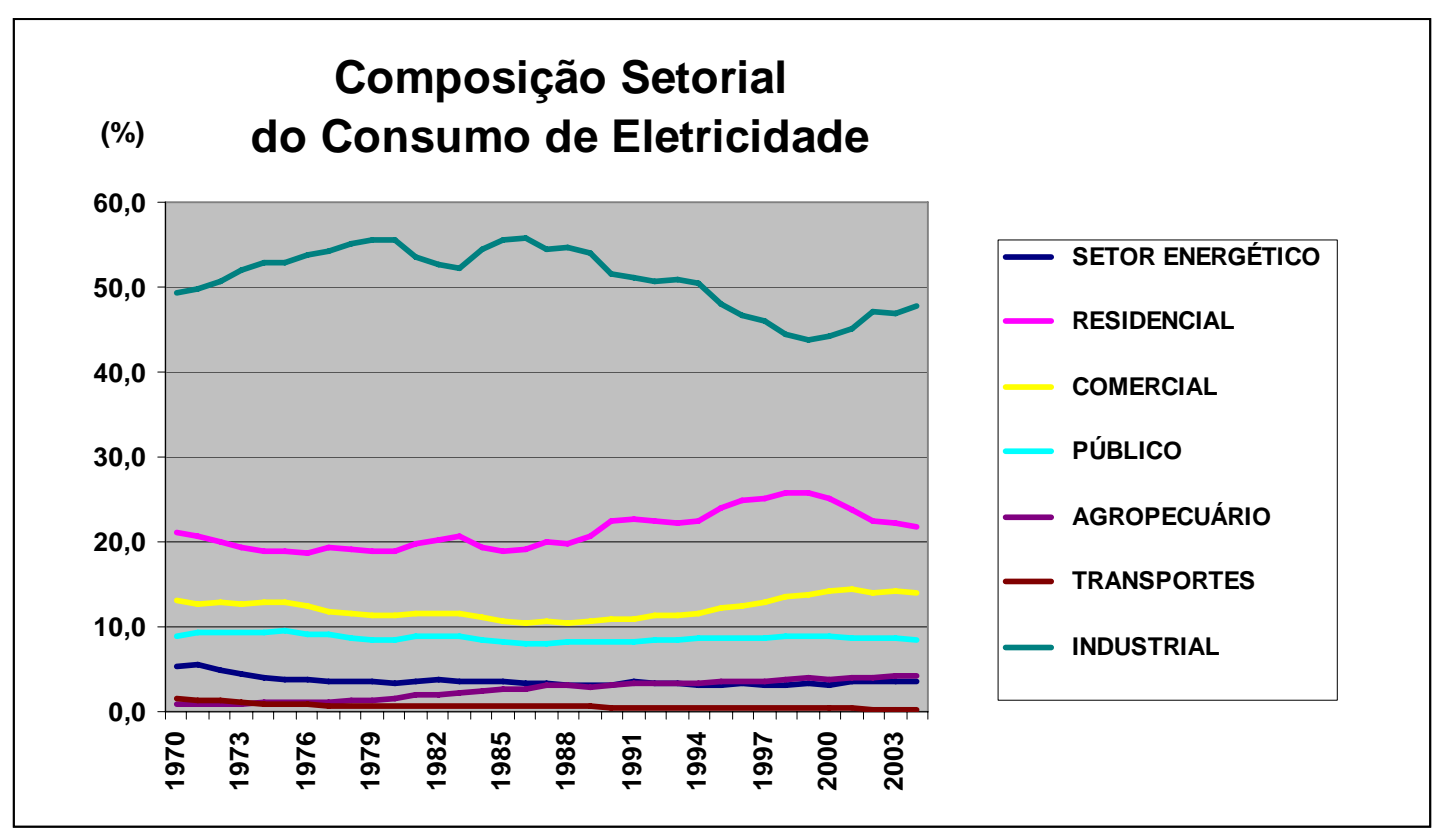

Figura 4.4.2. Consumo de Eletricidade por Setores. Fonte BEN 2005 [25] 


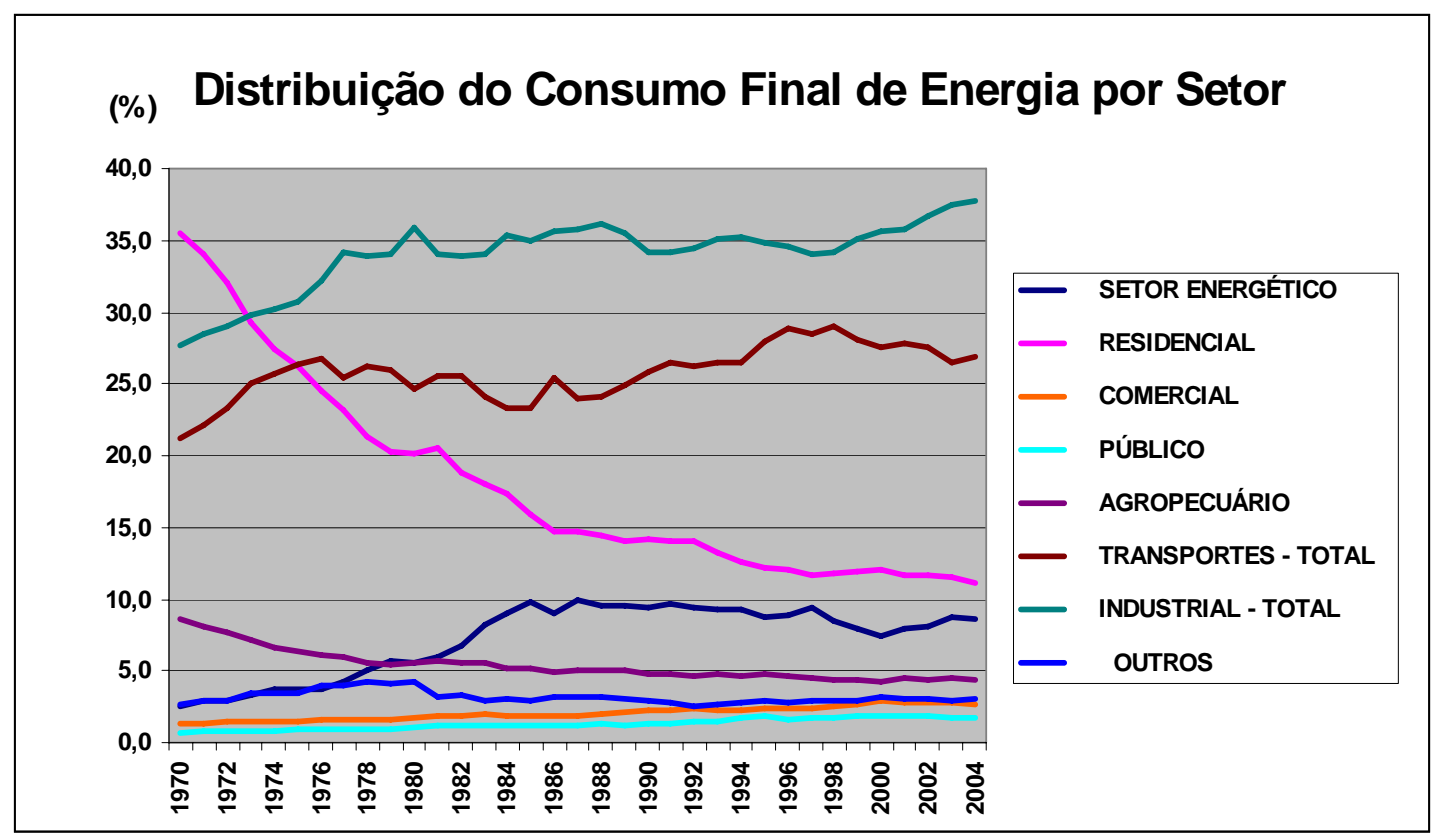

Figura 4.4.3. Consumo Final de Energia por Setores. Fonte BEN 2005 [25]

\subsubsection{Perfil da Demanda Residencial}

O setor residencial tem uma participação de $22 \%$ no consumo final de eletricidade e $11 \%$ no consumo final de energia, de acordo com o BEN 2005. Do ponto de vista energético, não é de grande representatividade por não possuir produto próprio, mas do ponto de vista social é extremamente relevante, representando a demanda energética das necessidades básicas essenciais da sociedade [20].

Quanto aos usos finais, a energia no setor residencial é destinada, basicamente, para as seguintes finalidades: cocção de alimentos, aquecimento de água, iluminação, condicionamento ambiental, conservação de alimentos, serviços gerais e lazer. A eletricidade do setor residencial, que em 2004 atendeu a mais de 40 milhões de domicílios, consumindo 84 TWh [25], atende principalmente aos usos finais de refrigeração (25\% a 30\%), aquecimento de água (25\% a 35\%) e iluminação (15\% a 25\%), que, somados, respondem por cerca de $80 \%$ do consumo do setor. 
A utilização de energia como um todo, no setor residencial, está intrinsecamente ligada ao nível de renda do domicílio; os níveis de consumo de grande parte da população nacional, muitas vezes insuficiente para o atendimento das suas necessidades mais essenciais, refletem sua condição social.

\subsubsection{Perfil da Demanda Comercial}

O setor comercial tem uma participação de $14 \%$ no consumo final de eletricidade e de cerca de 2,5\% no consumo final de energia, de acordo com o BEN 2005 [25]. Os principais tipos atividades exercidas neste setor estão representadas pelos seguintes estabelecimentos: hospitais, aeroportos, escolas/universidades, hotéis, igrejas, mercados, armazéns, restaurantes, shopping centers e serviços gerais. Dada a heterogeneidade destes serviços, torna-se mais complexo estimar a distribuição dos principais usos finais neste setor, representados principalmente pela iluminação, condicionamento ambiental e refrigeração. Além destes serviços energéticos, são também essencialmente utilizados a ventilação, o aquecimento de água e a cocção.

Desta forma, as principais ações de eficientização de energia para este setor são referentes à iluminação eficiente, utilizando-se lâmpadas de menor consumo de eletricidade, à otimização de sistemas de condicionamento ambiental e armazenamento de frio por termoacumuladores, à eficientização de sistemas de refrigeração (através da otimização de motores e da utilização de controladores de velocidade) e a utilização de combustíveis eficientes para a cocção. Além destas possíveis medidas, a adoção de projetos de edifícios eficientes baseados em princípios de arquitetura bioclimática é também capaz de reduzir o consumo dos usos finais de iluminação e condicionamento ambiental. 


\subsubsection{Perfil da Demanda Industrial}

O setor industrial conta com uma grande diversidade de indústrias, de perfil energético diferenciado de acordo com características do processo industrial realizado. Por um lado temos indústrias extrativas, de alta intensidade energética, e por outro indústrias de transformação, responsáveis pela fabricação de produtos alimentícios, têxteis, químicos, máquinas e montagem de veículos.

Estabelecimentos industriais voltados à produção de alimentos envolvem processos que exigem refrigeração, uso final que não se interrompe durante a noite. Já a indústria de cerâmica também registra diversas atividades, principalmente referentes aos fornos, ativos também fora do horário comercial. Apesar da diferenciação de perfis de consumo, pode-se apontar a força motriz, tanto elétrica como a combustão, como uso final de maior consumo no setor industrial. Usos finais de infra-estrutura, bastante significativos nos setores comercial e industrial, representam um consumo bastante limitado neste setor.

Como principais medidas relativas a este setor temos, portanto, a eficientização da força motriz e de sistemas de combustão e refrigeração através de seu redimensionamento e utilização de controladores de velocidade capazes de reduzir o consumo energético das tecnologias utilizadas. 


\section{Dimensões de Análise e Respectivos Atributos}

Após a primeira etapa, de descrição, discriminação e divisão dos recursos de demanda em grupos, procede-se à caracterização completa dos fatores relevantes à avaliação dos recursos. Nesta etapa, a caracterização descritiva de tais fatores ou atributos é baseada a partir do estudo dos recursos energéticos do lado da demanda, no qual são contemplados, de forma essencialmente qualitativa, impactos globais, positivos e negativos, oriundos de sua utilização. Estes impactos são divididos em quatro áreas ou dimensões: Técnico-Econômica, Ambiental, Social e Política.

A delimitação das condições de contorno de cada dimensão de análise é extremamente importante, para evitar que atributos ou fatores híbridos quanto à sua natureza sejam avaliados repetidamente, tendenciando a classificação final para um dado recurso. Pelo mesmo motivo, atributos podem também ser segmentados em sub-atributos, quando determinados aspectos demandarem uma análise particular e minunciosa. Estes sub-atributos são derivados de seus respectivos atributos, e a avaliação dos mesmos é embutida na avaliação final de cada atributo. Exemplificando, um atributo que possua um peso igual a $x$ dentro de sua dimensão de análise, pode ter sua avaliação fracionada em sub-atributos de peso 0,5x, 0,2x e $0,3 x$.

Cada atributo deve ser avaliado de acordo com sua relevância dentro da dimensão de análise. Assim, pode-se atribuir pesos diferenciados a atributos considerados cruciais dentro de suas dimensões. Na dimensão econômica por exemplo, o custo da energia economizada ou o custo do empreendimento são dois dos fatores essenciais para a análise. Já na dimensão ambiental, o nível de redução 
da emissão de gases de efeito estufa por conta do emprego de uma medida de GLD é de extrema importância para a obtenção de certificados de créditos de carbono.

Para a caracterização de recursos do lado da demanda, pode-se utilizar diferentes métodos de avaliação, desde uma análise de riscos até a avaliação de custos completos (ACC), ferramenta corrente no PIR. No caso da ACC, os atributos, além de uma diferenciação de peso, recebem uma avaliação dentro de escalas de valores qualitativos (ótimo, bom, regular, ruim) ou pontuações numéricas (valores nulos a máximos). Os recursos avaliados recebem notas, de acordo com os seus desempenhos nos diversos atributos de avaliação de cada uma das quatro dimensões de análise. Esta escala pode ser baseada em valores práticos, reais e exatos, como o tempo de retorno de um dado empreendimento (variável desde poucos meses até anos ou décadas), ou do nível de emissão evitada de material particulado a partir da substituição de um dado combustível por outro. Por outro lado, há muitos impactos externos e de atividades sociais e políticas, cujos indicadores não podem ser monetarizados e cujas escalas não são possíveis de serem associadas a valores numéricos. Mesmo um atributo técnico como, por exemplo, o potencial de um dado recurso em atender a necessidades específicas, é avaliado qualitativamente, em termos de baixo, médio e alto potencial de atendimento.

Desta forma, cada recurso energético terá uma avaliação dentro de cada dimensão. Estas avaliações são tratadas de forma equilibrada, de acordo com os preceitos do PIR, de forma a compor um resultado global balanceado, que não favoreça uma área ou dimensão em detrimento de outra. Assim, custos ou impactos técnico-econômicos são alocados conjuntamente com impactos de ordem ambiental, social e política, compondo uma avaliação imparcial e completa dos recursos 
energéticos. Dados de impactos externos e de atividades sociais e políticas são avaliados qualitativamente, podendo ser quantificados em alguns casos.

As quatro dimensões de análise consideradas neste modelo, vinculadas ao desenvolvimento e ao consumo sustentável, são descritas e explicitadas a seguir.

\subsection{Dimensão Técnico-Econômica}

Esta dimensão analisa aspectos técnicos e tecnológicos assim como fatores econômicos de recursos energéticos de demanda. É comumente contemplada em qualquer avaliação tradicional de empreendimentos energéticos e tem, no âmbito do PIR, sua importância dividida entre as demais dimensões de análise. Alternativas energéticas favoráveis do ponto de vista técnico-econômico obtém uma boa classificação nesta dimensão, independentemente de suas implicações ambientais ou sócio-políticas. Vale ressaltar, porém, que em determinados casos, uma avaliação técnico-econômica desfavorável é suficiente para invalidar um projeto, independentemente da avaliação nas demais dimensões, o que não desmerece a qualidade da caracterização modular dos recursos do lado da demanda.

Como alguns dos fatores técnicos avaliados podemos citar o know-how em relação a uma determinada medida de GLD, tais como controladores de demanda ou mesmo tarifas diferenciadas, e a aplicabilidade de um recurso de GLD na região ou situação estudada. Obviamente, a substituição da rede elétrica por outros combustíveis pode demandar uma análise mais complexa do ponto de vista técnico e ambiental. A perspectiva econômica, por sua vez, considera fatores de praxe, como o tempo de retorno do investimento dos recursos avaliados, o custo do empreendimento e da energia economizada, e o custo evitado a partir da aplicação 
de medidas de GLD. Segue, nos próximos ítens, uma breve descrição dos atributos mais relevantes à avaliação técnico-econômica de recursos do lado da demanda.

\subsubsection{Custo Efetivo do Empreendimento}

Este fator considera o custo total da implantação de um dado recurso do lado da demanda, podendo incorporar taxas internas de retorno (TIR) típicas para o risco do programa, além de eventuais incentivos e financiamentos. Em programas de GLD é importante considerar, em diversos casos, o ganho econômico oriundo da redução da demanda energética, além de benefícios provenientes de adicionalidades como a redução da emissão de poluentes e gases de efeito estufa, que fornecem a possibilidade de geração de certificados de créditos de carbono. Desta forma, o custo do empreendimento é medido em unidade monetária (dólares ou reais) gasta em função da demanda reduzida ou economizada. Relacionando-se recursos de demanda avaliados dentro de fatores técnicos e de mercado, pode-se estipular uma escala sugerindo valores considerados como altos, medianos e baixos, correspondendo a avaliações negativa, neutra e positiva, respectivamente.

\subsubsection{Custo de Energia economizada}

Este atributo, medido em unidade monetária por energia mede o custo total da energia consumida, incorporando-se custos referentes a equipamentos de uso final, assim como o custo de energia economizada, no caso de se avaliar a substituição de tecnologias de uso final.

Uma ação de eficientização tem sua viabilidade econômica atrelada à condição de que o custo da referida medida de eficiência energética e redução de consumo seja inferior à quantia monetária economizada a partir da mesma. Tal situação é possível em medidas de eficientização, como a substituição, no setor de transportes, de gasolina por gás natural veicular (conversão e adaptação de baixo 
tempo de retorno econômico). A escala referente a este atributo segue a linha adotada para o custo do empreendimento e varia igualmente em função dos demais recursos avaliados e de parâmetros de mercado e do setor energético.

\subsubsection{Potencial Relativo de Gerenciamento do Lado da Demanda}

Posto que os potenciais energéticos de conservação, em MWh/ano, são calculados em outra etapa do modelo, este atributo refere-se ao potencial energético de forma mais direcionada, analisando-se fatores cruciais como a região de implantação e os objetivos específicos da medida de GLD utilizada.

\subsubsection{Atendimento a Necessidades específicas}

O potencial de redução energética não é o único fator determinante para o sucesso de um recurso de GLD. Assim, este sub-atributo presta-se a avaliar programas de conservação e GLD em termos de propósito, efetividade e obtenção de resultados. Com isto, busca-se valorizar medidas de GLD que, acima de um potencial de redução energética alto ou baixo, sejam funcionais no cumprimento de seus objetivos. Temos como exemplo algumas pequenas ações de substituição de eletrodomésticos que, ainda que não sejam capazes de gerar um potencial global de redução elevado, provam-se bastante eficientes no atendimento a interesses múltiplos de uma dada região de estudo. Há ainda um importante grupo de medidas que visam o recorte de pico e o translado de carga da curva de demanda que, ainda que não impliquem em redução de consumo energético, repercutem no alívio do sistema em períodos de ponta e conseqüentemente na redução de gastos em eletricidade por parte da empresa ou consumidor. O consumidor reduz sua conta de energia, por conta da diminuição do uso da eletricidade em horários de ponta e, conseqüentemente, da demanda contratada para atender a estes picos de consumo. 
A maior uniformidade na curva de demanda de uma dada região pode repercutir indiretamente no adiamento da ampliação da geração elétrica por parte de empresas geradoras. A unidade e a escala de avaliação, neste caso, são por princípio qualitativas, posto que não se está analisando a quantidade de energia economizada e sim a funcionalidade de uma medida de GLD.

\subsubsection{Aplicabilidade do recurso na região}

Neste sub-atributo, foca-se no potencial de um recurso energético de demanda para uma dada região de estudo. Alguns recursos podem apresentar um bom potencial como, por exemplo, a substituição de sistemas de ar condicionado (se o consumo energético referente a condicionamento ambiental for comprovadamente elevado) ou a troca de combustíveis fósseis por combustíveis renováveis no setor de transportes (em casos comprovadamente elevados de consumo energético referente

a condicionamento ambiental). Desta forma, a avaliação deste potencial não é guiada apenas por fatores geográficos e naturais inerentes à região focada, como também por fatores político-econômicos inerentes aos recursos de GLD, como a difusão de informação e marketing e potencial de adoção de programas e medidas de eficiência em geral. Neste caso, avaliamos cada recurso de acordo com estimativas de potencial de redução energética, dentro de uma escala local, abrangendo desde baixos potenciais de redução a altos potenciais.

\subsubsection{Relação Custo/Benefício}

Este indicador mede a relação custo/benefício de um dado programa de GLD, a partir da relação entre os custos totais e os benefícios advindos de um determinado programa. O índice é calculado do ponto de vista do consumidor, podendo se estender a empresas de serviços de conservação energética, 
considerando o valor presente de custos de alteração da demanda por conta do programa executado e custo e valor do serviço de GLD oferecido, entre outros fatores. Já no caso do consumidor, além do custo e do valor do programa, são contemplados custos de operação, manutenção e instalação do equipamento, bem como seu tempo de vida do equipamento, alterações tarifárias, entre outros custos. A unidade utilizada para tanto é de $\mathrm{R} \$$ ganhos por $\mathrm{R} \$$ gastos, representando a fração entre a quantia gasta na implantação e execução de um programa de GLD e o ganho referente à energia economizada. Dos índices obtidos para cada recurso analisado, obtém-se uma escala de custos-benefícios, considerando a gama de resultados dos recursos avaliados, bem como fatores externos de mercado.

\subsubsection{Incentivos tarifários à adoção de programas de GLD}

Programas de GLD podem oferecer incentivos diretos ou implícitos, visando um bom índice de adoção, tais como: empréstimos ou pagamentos diretos a consumidores, reduções na fatura de energia, devoluções, minimização de investimentos iniciais do consumidor na aquisição de tecnologias de GLD, subsídios na instalação de equipamentos de controle de demanda, entre outros. Tais incentivos repercutem diretamente na redução do custo de programas de GLD e conseqüentemente no potencial de adoção dos mesmos. Assim, recursos são avaliados de acordo com uma escala qualitativa, variando desde a ausência de incentivos tarifários (avaliação nula) até incentivos substanciais (valor mais positivo).

\subsubsection{Tempo de Desenvolvimento e Implantação do Recurso}

Este atributo procura analisar intervalos de tempo médios para a obtenção de resultados de alteração de demanda e consumo energético. Como o escopo de recursos de GLD é muito amplo, temos medidas de rápida implantação e resultados, 
como a substituição de equipamentos ou a utilização de novas tarifas, e medidas de difícil avaliação e horizontes mais longos de implantação, como a difusão de informação quanto a hábitos de uso racional e a capacitação de profissionais no ramo da eficiência energética. Tais medidas contam ainda com a dificuldade de se manter um determinado nível de resultados obtidos quanto ao alcance de objetivos de economia energética, posto que alguns dos hábitos nacionais adquiridos durante o período de racionamento energético, em 2001, podem ter sido novamente deixados de lado diante de cenários circunstancialmente estáveis de provisão energética, como se pode observar em exemplos corriqueiros do dia a dia. Este atributo é medido em anos, e a escala de avaliação é formada de acordo com o horizonte de tempos de implantação dos recursos avaliados, em consonância com fatores de mercado e anseios do setor energético.

\subsubsection{Tempo de Retorno do Investimento}

O tempo de retorno e a taxa de retorno do investimento são fatores essenciais para a viabilidade de um empreendimento energético, seja ele do lado da demanda ou da oferta. $\mathrm{O}$ interesse do empreendedor, que pode ser tanto o consumidor residencial, quanto agentes de concessionária ou do setor industrial, é sempre o de buscar uma taxa interna de retorno superior à taxa de juros utilizada no financiamento de uma dada medida de GLD. Em relação ao tempo de retorno do investimento, o interesse do consumidor é de recuperar, no menor período de tempo possível, o valor investido em ações de GLD, sejam elas a conversão de combustíveis veiculares, a aquisição de equipamentos domésticos mais eficientes, o controle direto da demanda ou a utilização de tarifas alternativas. Nesta equação, o GLD se prova válido, na perspectiva econômica, quando seus custos totais são inferiores aos custos evitados de atendimento à demanda. O tempo de retorno é 
medido em anos e a escala de avaliação é composta a partir da amostragem de tempos de retorno dos diversos recursos do lado da demanda, além de contextos e fatores de mercado, como taxas de retorno adequadas para diferentes níveis de risco e tipo de investimento.

\subsubsection{Domínio Tecnológico do Recurso}

Este fator busca avaliar o conhecimento tecnológico da região de estudo em relação a um dado recurso energético de demanda. Para tanto, a caracterização da detenção deste conhecimento é dividida em três sub-atributos importantes: a existência local de tecnologia e equipamento ligado ao recurso energético, o conhecimento teórico e prático, bem como linhas de ação requisitadas pelo recurso de GLD avaliado e, por fim, a existência de um corpo técnico e profissional capacitado a atuar na área de implantação e desenvolvimento do recurso analisado.

\subsubsection{Tecnologia e Equipamento}

Analisa-se, neste sub-atributo, a procedência da tecnologia e dos equipamentos utilizados em medidas de GLD, sejam eles controladores de demanda, equipamentos de alto rendimento ou projetos eficientes de conservação de calor ou arquitetura bioclimática. Desta forma, os recursos avaliados são medidos qualitativamente, em uma escala que parte de um conceito negativo para a região de estudo, que seria um domínio tecnológico exclusivamente estrangeiro e, portanto, de maior custo e grau de dificuldade de implantação e prosseguimento, chegando a um nível altamente positivo, que seria o domínio amplamente nacional da tecnologia utilizada, sem maiores restrições para sua aplicação. 


\subsubsection{Base Teórica}

Este sub-atributo refere-se ao know-how de uma medida de GLD, em termos de conhecimento teórico, e experiência prática, assim como o planejamento da metodologia e a definição da linha de ação adotada. Em suma, avalia-se neste subítem o know-how da implantação de um recurso de GLD, considerando a experiência e a tradição no gerenciamento de um dado recurso como fundamental para suas chances de sucesso. Desta forma, a caracterização completa dos recursos do lado da demanda é feita dentro de uma escala cujas extremidades seriam a experiência inexistente na região de estudo focada, do lado negativo, e o domínio completo na região de estudo, como caso mais positivo.

\subsubsection{Formação e disponibilização de pessoal}

Este sub-atributo avalia a disponibilidade de profissionais capacitados e provedores de serviços na área de eficiência energética aptos a conduzir o recurso de GLD avaliado. Sem este corpo de especialistas, a execução e prática de uma determinada medida de GLD fica seriamente comprometida ou mesmo impossibilitada. A avaliação neste caso não é feita a partir de estatísticas, e sim de valores em escala qualitativa abrangendo desde avaliações negativas, como no caso da inexistência de pessoal capacitado na região focada, até perspectivas positivas, no caso de capacitação profissional amplamente abundante.

\subsubsection{Grau de Necessidade de Monitoração e Manutenção}

Procura-se avaliar aqui, o nível de controle, ou manutenção e monitoração, requeridos por um determinado programa de GLD, tanto pela duração e regularidade do apoio necessário, quanto pela complexidade do serviço de assistência. Este atributo é de grande importância na avaliação de um programa de GLD, posto que o 
controle ou a monitoração de um programa são essenciais para o alcance de seus objetivos. Considerando que os diferentes recursos analisados neste modelo variam consideravelmente quanto a aplicação, finalidade e linha de ação, temos diferentes graus de monitoração demandada. Na dimensão técnico-econômica, a monitoração é considerada em um nível microscópico, quanto à manutenção de equipamentos em residências e industrias. Já na dimensão política, a monitoração de políticas de GLD é tratada de forma geral, a partir da avaliação de resultados e do estudo de comportamento de programas. Sendo assim, pretende-se, no âmbito técnico, avaliar a necessidade da assistência de um determinado recurso de GLD quanto a freqüências de acompanhamento e especialização técnica requerida. Tais fatores são de extrema importância para as chances de sucesso de um programa de GLD, posto que em medidas que visem o controle de demanda o nível de aquisição de controladores ou aparelhos afins é proporcional à sua operacionalidade e praticidade. O mesmo aplica-se à conversão de veículos ou aparelhos de condicionamento ambiental para outros combustíveis, no tocante à assistência técnica para a adaptação de motores e equipamentos. A avaliação da manutenção requerida é preferencialmente qualitativa, apesar da possibilidade de se utilizar índices relativos à freqüência de atendimentos em um dado período de tempo.

\subsubsection{Qualidade da energia gerenciada}

Este atributo técnico pretende avaliar implicações e impactos oriundos de medidas de eficientização energética, como substituições de tecnologias e equipamentos e controle de demanda na rede elétrica e qualidade da energia processada. 


\subsubsection{Alterações na qualidade da rede elétrica como um todo}

Neste item mede-se o nível de alterações à rede provocadas por medidas de GLD, mais especificamente, alterações de parâmetros desde a concessionária, visando a redução do consumo. Tais parâmetros (fator de carga e fator de potência) influenciam de forma direta na qualidade da energia fornecida à rede, implicando em impactos diretos de afundamento de tensão e alterações na sensibilidade de equipamentos. Estes impactos gerais repercutem, por fim, na redução da capacidade do sistema elétrico. Esta qualidade é proporcional ao cumprimento de especificações referentes a esses indicadores energéticos. A avaliação é qualitativa, em escala variando desde um nível atribuído de baixa qualidade de energia até um nível alto, de melhoria da qualidade da energia fornecida à rede.

\subsubsection{Alterações na qualidade de energia consumida}

A substituição de equipamentos eletrodomésticos, motores ou lâmpadas tem implicações diretas em parâmetros como a geração de harmônicos, de transitórios, ou a alteração do fator de potência. De forma análoga ao sub-atributo anterior, podese obter uma energia de qualidade superior ou inferior a partir dessas medidas de GLD. Mede-se, portanto, de forma qualitativa, a interferência de tais ações, em índices situados dentro de uma escala que considera desde melhorias consideráveis na qualidade de energia (valor positivo) à diminuição considerável na qualidade da energia consumida (valor negativo).

\subsubsection{Estrutura de Marketing e Propaganda Estratégica}

A aderência ou adoção de consumidores de diversos setores energéticos a programas de GLD é evidentemente um requisito fundamental às suas chances de sucesso. Para tal adesão, temos o marketing e a propaganda relacionada a 
programas ou iniciativa de GLD como a principal ferramenta. A divulgação de um programa, além de aumentar o conhecimento popular sobre o mesmo, tem o papel de influenciá-los a optar por determinado tipo de tecnologias e usos finais [8]. Neste atributo, é avaliada a espécie de plano de marketing ou divulgação utilizada para cada recurso do lado da demanda analisado, dentre elas ações como: informação incluída na conta da concessionária para os consumidores da área, malas diretas, material de propaganda para lojas ou estabelecimentos vendedores de tecnologias eficientes, propagandas em jornais, revistas ou televisão, treinamento de vendedores de lojas de eletrodomésticos para informação sobre programas e produtos ao cliente, inclusão de selos de eficiência energética em equipamentos, conferências de imprensa para lançamento de projetos, realização de pesquisas pública para a identificação de características dos potenciais consumidores interessados (no tocante a impressões sobre o desperdício de eletricidade, mensagens adequadas para o sucesso do projeto, e sugestões de preços viáveis de equipamentos ou programas). Na escala de avaliação de recursos do lado da demanda, quanto à estrutura de marketing e divulgação tem-se, na extremidade negativa, recursos que não contam com nenhum esquema vinculado de promoção ou divulgação; por outro lado, recebem avaliação máxima recursos que contam com amplo planejamento e estratégia de propaganda.

\subsection{Dimensão Ambiental}

Esta dimensão trata de impactos provocados por recursos energéticos do lado da demanda ao meio ambiente. Uma vez que toda forma de geração energética incorre inevitavelmente em impactos ao meio ambiente, em menor ou maior escala, tem-se que medidas de gerenciamento do lado da demanda são capazes de proporcionar, 
em muitos casos, a redução de alguns desses impactos, ou seja, a produção de impactos positivos ao meio ambiente. Como exemplos desse tipo de impactos podese citar a poluição atmosférica evitada (pela substituição de energéticos ou combustíveis no setor de transportes) e o uso evitado da água (pela postergação da ampliação da oferta energética e conseqüentemente, da necessidade de construção de usinas hidrelétricas ou termelétricas). Por outro lado, recursos do lado da demanda também podem implicar em impactos negativos ao ambiente, entre os quais o descarte, em médio e longos horizontes de tempo, de equipamentos para o controle da demanda, e em curto prazo, de lâmpadas fluorescentes compactas, implicando na liberação de vapor de mercúrio ao ambiente.

\subsubsection{Poluição Atmosférica}

Este ítem trata do acréscimo ou decréscimo de emissões de poluentes à atmosfera a partir de diferentes substâncias, como gases provocadores de efeito estufa, material particulado ou vapor de mercúrio, a partir da substituição de equipamentos ou da seleção de combustíveis, como recursos do lado da demanda. Em alguns deles, como a substituição de combustíveis nos usos finais de aquecimento ou transporte, as diferenças em emissões podem ser calculadas de forma direta. Já na maioria dos casos de medidas de GLD, a diminuição de impactos referentes à poluição atmosférica é de difícil mensuração. Uma vez que a energia economizada é de procedência não-determinada, para o levantamento da emissão de poluentes é necessário estipular uma linha de base a partir da matriz energética e dos níveis de emissões da região estudada. Assim, seria possível calcular, em toneladas equivalentes de carbono, a quantidade de emissões evitadas a partir da adoção de programas de GLD, utilizando a unidade toneladas de carbono por MWh de energia economizada, para a contabilização das emissões. A escala de 
avaliações pode ser composta por valores obtidos de toneladas equivalentes de carbono para os diferentes recursos de GLD avaliados. No estudo de caso, porém, para efeito de simplificação, utilizou-se uma escala qualitativa contemplando o caso de poluição atmosférica evitada no extremo positivo e de poluição considerada no caso negativo. Desta forma, diferentemente de outros atributos nos quais a escala varia de zero a um valor máximo positivo, tem-se, neste caso, uma escala com extremidades negativa e positiva, posto que a adoção de programas de GLD pode gerar tanto reduções quanto acréscimos de emissões de poluentes.

\subsubsection{Poluição das Águas}

A poluição das águas, na implantação de recursos energéticos de demanda, está relacionada à estimativa de impactos causados ou evitados por medidas de GLD como a substituição de combustíveis ou a substituição do uso da rede por geradores ou outros equipamentos. O descarte de lâmpadas fluorescentes também implica em impactos negativos à água, uma vez que o lançamento de vapores de mercúrio em aterros pode contaminar o solo e, subseqüentemente, os cursos d’água.

Desta forma, o potencial de alguns dos recursos de GLD em poluir as águas é indireto e consolidado por meio de uma linha de base ponderando a variação, por conta de ações de GLD, do uso de recursos energéticos de oferta potencialmente poluentes às águas. A avaliação deste atributo é qualitativa, em escala de extremidades negativa (poluição considerável da água) e positiva (redução de impactos aquáticos). Por outro lado, a quantificação destes impactos seria possível em casos comprovados de postergação de usinas hidrelétricas ou termelétricas por conta da conservação e do gerenciamento da demanda energética. 


\subsubsection{Poluição do Solo}

Valem, para este atributo, as mesmas observações referentes à poluição das águas. Impactos negativos relativos à poluição do solo podem, em alguns casos ser minimizados através de ações de eficientização energética e gerenciamento do lado da demanda. Impactos negativos podem ser reduzidos por meio da substituição de recursos que impliquem em impactos ao solo, sejam eles impactos decorrentes da necessidade de criação de aterros, ou impactos referentes à transmissão ou ao transporte de energia. Outros tipos de substituição de recursos, como a utilização de lâmpadas fluorescentes, mistas e de vapor de sódio e de mercúrio, podem contaminar o solo com a liberação de vapor de mercúrio. A escala para a avaliação deste atributo também é preferencialmente qualitativa, abrangendo desde impactos consideráveis (extremidade negativa) até casos de redução de impactos ao solo (extremidade positiva).

\subsection{Dimensão Social}

Esta dimensão considera impactos provocados por recursos energéticos na qualidade de vida e no bem-estar da sociedade como um todo, representados por fatores como: Efeitos do desequilíbrio ambiental no meio social, Benefícios Sociais decorrentes da tarifação, Influência do Recurso de Demanda na Atividade Econômica/Comercial/Industrial e Infra estrutura locais, Contribuição ao Desenvolvimento da Educação da Região, Influência no Mercado de Trabalho Aumento e Redução de Empregos. Tal qual a dimensão ambiental, os impactos sociais advindos de recursos do lado da demanda podem, em muitos casos, ser positivos à sociedade quanto a saúde e bem estar, uma vez que a postergação indireta da ampliação de geração de energia minimiza uma série de impactos 
ambientais correlatos, de repercussão direta na qualidade de vida da população da região de estudo. Por outro lado, a adoção de medidas de GLD é capaz de trazer benefícios sociais quanto à conscientização sobre o uso racional de energia e a tarifação diferenciada em classes econômicas. A seguir, são descritos os principais atributos da dimensão social, acompanhados de indicações referentes à sua avaliação.

\subsubsection{Considerações funcionais e estéticas de Recursos}

A utilização de controladores da demanda elétrica ou mesmo a substituição de eletrodomésticos ou outros equipamentos por tecnologias mais eficientes é capaz de interferir de forma estética ou funcional no ambiente interno. Estas alterações podem ser negativas em termos de decoração ou de praticidade diária, principalmente no setor residencial. Desta forma, este tipo de consideração quanto à escolha de equipamentos é governada por fatores sócio-psicológicos do consumidor de energia e este requisito de análise, ainda que pouco técnico, exerce influência direta na escolha de equipamentos modernos e eficientes ou na adoção de programas de GLD. A avaliação deste atributo, pelo grau de subjetividade e particularidade, deve ser de ordem qualitativa, dentro de uma escala que avalie recursos desde um grau inaceitável de alteração estética e funcional até um patamar agradável quanto à interferência no ambiente interno.

\subsubsection{Efeitos do desequilíbrio ambiental no meio social}

A utilização de recursos de eficientização energética é capaz de minimizar impactos negativos referentes à repercussão da geração elétrica em diferentes áreas sociais como a saúde pública, a agricultura, a poluição externa de edificações e a poluição sonora, ou mesmo a ocupação de espaços destinados inicialmente a 
outros usos. Esta minimização ocorreria de forma apenas tangencial, e seria estimada, a grosso modo, em função da minimização desses impactos negativos a partir do controle da expansão da oferta energética ou da substituição de energéticos poluentes por outros renováveis. Desta forma, tais impactos seriam avaliados desde desequilíbrios de alto efeito (avaliação negativa) até a minimização de impactos ambientais no meio social (avaliação positiva).

\subsubsection{Impactos Sociais decorrentes da estrutura de preços e tarifação}

Este atributo é específico para o recurso de precificação para o gerenciamento da demanda, posto que a composição e o perfil de tarifas funcionam como um sinal econômico à adoção de programas de GLD. Tarifas crescentes para blocos de consumo, por exemplo, podem privilegiar consumidores de baixa renda que tenham um baixo consumo. Assim, pretende-se avaliar, de forma qualitativa, tarifas energéticas de acordo com potenciais benefícios a camadas de baixa renda ou mesmo de renda média, partindo de um valor negativo (prejuízos sociais, no caso de tarifações incoerentes) até benefícios consideráveis, no caso de tarifas módicas para consumidores de baixa renda. Vale lembrar, contudo, que tarifas módicas não necessariamente implicam em redução de consumo de eletricidade. Segundo Januzzi, ainda, a adoção de uma política de preços reduzidos de energia elétrica não garante o desenvolvimento industrial de uma região, o qual vai depender de muitos outros fatores, especialmente da disponibilidade de mão-de-obra especializada, do custo dessa mão de-obra, de eventuais incentivos fiscais e da existência de uma infra-estrutura adequada [36]. 


\subsubsection{Influência no Desenvolvimento de Atividades Econômicas, Comerciais, Industriais e Infra-Estrutura local}

A aplicação de medidas e a implementação de programas de GLD em uma dada região pode gerar uma série de oportunidades de desenvolvimento de novas frentes de negócio, resultando em benefícios positivos para a economia local como um todo, em termos de geração de empregos diretos e indiretos (vide item 7 desta mesma dimensão) e arrecadação de impostos [34]. O incentivo parcial ou total à venda de equipamentos eficientes ou substituição de fontes energéticas é igualmente capaz de promover o desenvolvimento dos setores comercial e industrial. Tal desenvolvimento pode ser medido qualitativamente, desde níveis insignificantes, passando por influências moderadas e médias até grande influência no desenvolvimento de atividades locais por conta da implantação de programas.

\subsubsection{Contribuição ao Desenvolvimento da Educação da Região}

Neste caso, pretende-se aferir a capacidade indireta de um recurso energético do lado da demanda em contribuir ao desenvolvimento de uma região específica quanto à educação. Para tanto é considerada a capacidade de medidas de GLD, como o controle de demanda e a utilização de geradores ou coletores solares, em aliviar um sistema limitado, no caso de comunidades isoladas, e assim disponibilizar um excedente energético que possa contribuir a aplicações de uso de energia para fins educativos ou mesmo de saúde. Sendo assim, impactos positivos ou negativos de recursos quanto ao desenvolvimento educacional de uma região seguiriam uma escala de extremidades nulas (no caso de um recurso que não afeta

o desenvolvimento regional da educação) até o valor máximo (recursos positivos à educação regional). Tal atributo não poderia, no entanto, ser aplicado a estudos de 
caso de regiões maiores ou de setores comerciais ou industriais, dada a ausência, nestes casos, de conexão entre o GLD e o uso de energia para fins educativos.

\subsubsection{Influência no Mercado de Trabalho - Geração de Empregos}

A implantação de programas de GLD requer a formação de equipes de trabalho, possibilitando o emprego, em empresas de serviços energéticos, de profissionais de diferentes graus de capacitação. Assim, cada tipo de recurso envolverá uma quantidade de pessoal empregado em funções de diferentes níveis de complexidade e remuneração. Vale mencionar que, em alguns casos, a adoção de medidas de GLD pode repercutir negativamente na disponibilização de empregos, reduzindo seu número no caso de um hipotético retardamento da ampliação da geração energética, ou mesmo da transmissão e da distribuição. A este atributo pode-se vincular índices numéricos de aumento/diminuição de empregos ou utilizar escalas qualitativas como influência negativa, nula, média ou alta no mercado de trabalho da região ou área focal.

É importante realçar que a venda e a manutenção de equipamentos, além da provisão de serviços energéticos, podem contribuir diretamente ao aquecimento do comércio e ao desenvolvimento econômico de um determinado local na medida em que tais atividades são realizadas e tem sua renda arrecadada neste mesmo local. A fabricação de equipamentos, por outro lado, por não ser necessariamente realizada no local de aplicação, pode ter benefícios relacionados ao aumento de empregos desviados para o local de produção dos referidos equipamentos.

\subsection{Dimensão Política}

Nesta quarta e última dimensão são analisados atributos referentes a fatores diretamente políticos como o apoio governamental a um determinado recurso 
energético, por meio de incentivos ou subsídios, fatores político-econômicos, como o risco da utilização de recursos energéticos importados à exposição cambial ou mesmo questões relativas à posse de recursos e detenção de tecnologias energéticas. Porém, o aspecto fundamental desta dimensão é a análise da interação entre os Envolvidos e Interessados (En-In) da questão energética local, a partir do poder de decisão e dos interesses particulares de cada um desses grupos em relação à viabilização de recursos energéticos do lado da demanda. A interação entre os En-In é analisada no modelo em atributos como a aceitação ou a oposição de atores energéticos a um determinado recurso, a conjunção de interesses entre agentes envolvidos e a participação e influência no uso da energia, entre outros. Ainda que à primeira vista tais atributos indiquem um perfil essencialmente social, neste modelo são reservados à dimensão social impactos que atinjam a sociedade como um todo, ao passo que impactos referentes a grupos específicos da sociedade e da área energética focada são alocados na dimensão política.

O envolvimento público no gerenciamento de recursos caracterizado pela inclusão dos En-In no processo de planejamento energético constitui, conforme mencionado previamente, uma das etapas ou premissas básicas do PIR e visa atender a diversos propósitos como: garantir que valores públicos sejam refletidos em decisões políticas e levantar informações acerca de impactos à sociedade que seriam a princípio negligenciados, enfim, proporcionar um processo de planejamento considerado justo, tanto do ponto de vista público como do ponto de vista privado, exemplificado pelo respeito aos contratos e à propriedade privada. O alcance desses objetivos é capaz de contribuir potencialmente à obtenção de apoio público no processo de decisão e no consenso de seus resultados. 
Vale lembrar que a participação dos En-In no processo do PIR não se restringe à Dimensão Política na Avaliação de Custos Completos; seu envolvimento está incluído em diversas outras etapas práticas da realização do PIR, através da participação popular em diferentes meios informativos (pesquisas de opinião, oficinas, workshops) ou participativos (audiências públicas, integração em ONGs, conselhos e comitês). A seguir, são descritos os atributos contemplados nesta dimensão política de análise de recursos energéticos.

\subsubsection{Posse Estratégica do Recurso do Lado da Demanda}

Este primeiro atributo pretende caracterizar recursos energéticos quanto ao seu grau de controle por parte do indivíduo, de grupos ou setores específicos ou da sociedade. Desta forma um recurso livre representa seu mais alto grau de manuseio e disponibilidade perante a sociedade ou o anseio individual em utilizá-lo. Em outro extremo, um recurso privado tem sua utilização restrita a grupos ou corporações específicas, o que pode cercear, de certa forma, seu potencial de utilização e disseminação.

\subsubsection{Aceitação/Oposição a Recursos do Lado da Demanda}

A aceitação, em um extremo, e a oposição, em outro, de um determinado recurso energético por parte de um setor energético ou social pode ser preponderante para sua viabilidade e implantação. Tal afirmação pode ser comprovada em exemplos de mobilização de grupos, ou mesmo de uma população inteira, afetados em diferentes graus por empreendimentos energéticos que ameacem seu bem estar e sua qualidade de vida. No caso específico de recursos energéticos do lado da demanda, não se verifica tal grau de conscientização e mobilização, uma vez que tais recursos não são capazes de influenciar um grupo 
social de forma tão negativa. Por outro lado, o GLD apenas será bem sucedido em seus objetivos de conservação e uso racional e sustentável da energia se a adoção de ações e programas de fato ocorrer por parte dos consumidores (sejam eles residenciais ou industriais, da sociedade em geral e da concessionária ou empresa provedora de tais serviços). Os sub-atributos deste item não podem ser mutuamente avaliados, uma vez que a execução do modelo de caracterização de recursos do lado da demanda foca-se em um setor de consumo por vez.

\subsubsection{Consumidores residenciais}

A aceitação e a adoção de programas de GLD por consumidores residenciais está condicionada a diversos fatores, alguns dos quais avaliados em outras dimensões [8]. São eles, basicamente:

- incentivos ou descontos tarifários (ou ainda gastos adicionais reduzidos na aquisição de equipamentos eficientes ou de GLD);

- efeitos e implicações em serviços residenciais básicos, como a provisão regular de água aquecida e o condicionamento ambiental;

- marketing de diferentes tipos, desde propagandas a campanhas informativas, cuja intensidade é comumente proporcional ao nível de participação de consumidores em programas.

Considera-se, em sua caracterização quantitativa e qualitativa, que o nível de aceitação ou popularidade de um programa de GLD recebe valores máximos quando verificada uma potencial alta aceitação, e valores mínimos para o caso de baixa aceitação ou adoção. Ao contrário do que ocorre em recursos de oferta, em situações nas quais energéticos altamente poluentes ou negativos do ponto de vista social recebem altos índices de rejeição, é rara a identificação de casos de oposição 
explícita a um dado recurso do lado da demanda. Sendo assim, a classificação de oposição total da população a um recurso de GLD não seria aplicável a princípio.

\subsubsection{Consumidores industriais e comerciais}

Este perfil de consumidores diferencia-se do consumidor residencial, posto que o processo de decisão quanto à condução de medidas de GLD é obviamente mais complexo nos setores comercial e industrial, no que se refere aos seguintes aspectos [8]:

- A modificação de construções ou processos referentes a usos finais;

- A tomada de decisão a partir de grupos hierárquicos representando interesses de diferentes áreas como a financeira, empresarial, de engenharia, de linha de produção, entre outras;

- Limitações quanto ao redirecionamento de recursos e pessoal à execução e monitoramento de atividades de gerenciamento de demanda;

- Perspectiva da energia elétrica como um custo gerenciável e optimizável conforme o tipo de contrato acordado com a concessionária ou alternativas de auto-geração ou cogeração.

De forma análoga ao sub-atributo anterior, este tipo de consumidor é aferido em escala variando desde uma baixa aceitação até uma alta aceitação da medida de GLD considerada.

\subsubsection{Concessionárias e Empresas de Serviços Energéticos}

A opção de concessionárias e empresas energéticas em oferecer aos consumidores programas de GLD é capaz de prover alternativas à obtenção de energia ao consumidor, através da compra de energia de outras concessionárias ou de produtores independentes. Desta forma, a concessionária, ao promover 
programas de GLD, equipara, a partir de sua perspectiva, aspectos positivos e negativos, tais como:

- Melhorias de ordem técnica e eficiência operacional no uso da energia, além da comercialização de novos serviços ao consumidor, possibilitando um aumento de competitividade no setor;

- Gerenciamento, ainda que indireto, do risco de ampliação do sistema energético a partir da construção de novas usinas diante de incertezas quanto à projeção da demanda;

- Impactos negativos referentes à possibilidade de diminuição de receita de venda de energia, ou da inviabilidade de programas de GLD diante das diversas opções de aquisição de energia mencionadas anteriormente, da auto-produção do lado da demanda e da possibilidade do barateamento de novas formas de suprimento por conta do crescimento da competitividade entre empresas fornecedoras de energia.

Sendo assim, temos níveis altos de aceitação e adoção como extremidade positiva de uma escala composta pelo inventário da caracterização quantitativa e qualitativa de recursos e, diferentemente da avaliação de consumidores, pode-se registrar uma oposição ou rejeição total como extremidade negativa de avaliação de um recurso de GLD.

\subsubsection{Sociedade em Geral}

Neste atributo, temos a perspectiva geral da sociedade em relação a programas de GLD, cuja implementação bem sucedida pode oferecer benefícios diretos e indiretos, muitos dos quais considerados em outras dimensões, como benefícios econômicos e ambientais. A sociedade, mais do que os demais En-In envolvidos na problemática do GLD, tem no grau de conscientização ou instrução 
acerca de um determinado recurso um requisito determinante à sua aceitação ou rejeição. Em outras palavras, os fatores que regem a aprovação da população quanto à adoção de um recurso de GLD são primordialmente o grau de conhecimento ou familiaridade com a tecnologia ou ação de GLD envolvida, ou mesmo a consciência de seus potenciais impactos de ordem geral. Desta forma, o procedimento para a caracterização completa da aceitação social de um recurso do lado da demanda é similar ao utilizado nos demais atributos, a partir de uma escala variando desde baixa até alta aceitação.

\subsubsection{Apoio Governamental}

Este atributo pretende avaliar o apoio governamental a recursos de GLD, tanto em mecanismos de incentivo, quanto no desenvolvimento e acompanhamento de programas. Cada aspecto constitui um sub-atributo separado, avaliado independentemente.

\subsubsection{Mecanismos de Incentivos ou Restrições e Implicações Regulatórias}

O apoio governamental a políticas de GLD manifesta-se diretamente através do desenvolvimento de mecanismos de incentivo, que podem favorecer economicamente investimentos de concessionárias na conservação do uso final. A criação de tais incentivos parte de uma estrutura regulatória transparente e estável, que também se encarregaria de reforçar e definir metodologias de normatização quanto a padrões de eficiência de equipamentos e tecnologias, essencial para o uso racional da eletricidade [67]. Assim, avalia-se, no estudo de caso em questão, a assistência do governo a políticas de eficientização energética quanto a mecanismos regulatórios e incentivos. A avaliação abrange desde parâmetros negativos de avaliação, como restrições e implicações governamentais a um dado recurso, até 
incentivos econômicos elevados, do ponto de vista de investidores e concessionárias.

\subsubsection{Desenvolvimento da implantação e acompanhamento de recursos}

Este sub-atributo pretende caracterizar, em âmbito qualitativo, o desenvolvimento da implantação e o acompanhamento de políticas e programas por parte do governo. Tal monitoração é essencial para a determinação dos reais potenciais de redução energética de programas de GLD, possibilitar a modificação, expansão ou até o cancelamento dos mesmos e, por fim, mensurar de forma segura os resultados alcançados. Recursos do lado da demanda podem ser considerados factíveis enquanto recursos energéticos ou disponibilizadores de energia desde que sejam comprovados resultados positivos de redução de demanda ou consumo energético. Desta forma, a monitoração de programas de GLD com a devida verificação de resultados é absolutamente imprescindível para um planejamento que pretenda contemplar recursos do lado da demanda. Este quesito será medido de forma qualitativa, a partir de uma escala considerando desde o pior cenário, que seria a descontinuidade do referido programa associado ao recurso analisado, até a situação mais positiva possível, de monitoramento adequado do programa.

\subsubsection{Conjunção e Encontro de Interesses}

Uma vez considerados os Envolvidos e Interessados relacionados à implantação de políticas de GLD, verificou-se a necessidade não apenas de caracterizar a posição dos mesmos de forma individualizada, mas também sua interação conjunta. Tal atributo pretende, assim, ressaltar e analisar casos em que a 
viabilidade de recursos pode ser comprometida por conta de interesses discrepantes de agentes energéticos específicos.

\subsubsection{Consumidor Residencial, Industrial e Comercial}

Medidas de conservação energética, como o emprego de determinadas tarifas, tendem a privilegiar determinado setor em detrimento de outro, como no caso de tarifas por blocos crescentes ou decrescentes de consumo. Há ainda uma discrepância entre o valor das tarifas de eletricidade dos setores industrial, comercial e residencial, além de taxas diferenciadas de juros e conseqüentemente diferentes incentivos para investimentos em políticas de eficiência. Por outro lado, há recursos de GLD que podem ser adotados por todas as categorias de consumidor, sem qualquer tipo de conflito. Assim, podemos avaliar este sub-atributo em uma escala contendo avaliações negativas, no caso de alto grau de conflitos de interesses, e avaliações positivas, para casos de conjunção elevada de interesses.

\subsubsection{Consumidores e Concessionária}

Aqui pretende-se caracterizar a convergência ou divergência de interesses entre consumidores e potenciais clientes de serviços energéticos de GLD e a empresa de serviços energéticos encarregada de provê-los. No estudo de caso realizado, a avaliação de tal sub-atributo segue a escala do item anterior, partindo de valores negativos (acentuado conflito de interesses) a uma avaliação positiva (consenso de interesses).

\subsubsection{Risco a Exposição Cambial}

O fator de risco a exposição cambial, ou seja, a susceptibilidade a variações imprevistas de moedas estrangeiras, direciona-se principalmente para o caso de 
recursos do lado da demanda que envolvam tanto tecnologias e equipamentos de procedência externa. Tal fator, extremamente suscetível a fatores externos políticos

e econômicos, pode ser decisivo para a implementação de um dado recurso energético. Sendo assim, a escala elaborada para caracterização deste atributo parte de extremos negativos de qualificação, no caso de tecnologias importadas com grande influência de câmbio nos fluxos de caixa, sugere valores regulares para tecnologias mistas com risco parcial cambial nos fluxos de caixa, e recebe, no estudo de caso, a avaliação mais positiva no caso de tecnologias nacionais sem risco cambial nos fluxos de caixa.

\subsubsection{Potencial conscientização do uso racional e participação no gerenciamento da energia}

A caracterização qualitativa deste fator pretende aferir o potencial de um recurso do lado da demanda em termos de influenciar mudanças significativas nos hábitos de consumo energético de consumidores do setor residencial, bem como profissionais dos setores comercial e industrial. Desta forma, este atributo pretende valorizar recursos que estimulam o poder de decisão e controle do usuário de energia, em todos os setores. A educação de empregados de empresas ou indústrias sobre a natureza da questão energética é capaz de conscientizá-los quanto à importância de suas atividades e sua contribuição na resolução do problema, fomentando um maior senso de responsabilidade em direção ao uso racional de energia. A partir de impactos referentes a precificação de tarifas e freqüência e qualidade de propaganda e informação acerca de um dado recurso pode-se inferir, ainda que subjetivamente, seu potencial de incentivo ao uso racional e à economia de energia. 
Este potencial tem obviamente um peso inferior a uma real conscientização acerca do uso racional, impossível de ser mensurada previamente e de difícil estimativa após a implantação de um determinado recurso. É importante ressaltar que esforços no sentido de modificar hábitos de consumo devem ser constantemente reforçados a fim de se alcançar resultados duradouros quanto à educação e à criação de consciência em direção ao uso racional de energia e equipamentos energéticos eficientes.

Este atributo é essencial para a criação de consciência e a formação de um padrão sustentável de comportamento de consumo energético. Sua aferição, porém, deve ser recomendavelmente qualitativa, considerando-se a série de elementos nãoexatos e de cunho psicológico inerentes a ele. Assim, recursos que valorizam o papel do consumidor como tomador de decisão recebem avaliações positivas (tais como controladores de demanda) e recursos cujo processo de decisão passa pelo consumidor de forma marginal recebem avaliações negativas. 


\section{Potencial Energético de Recursos Energéticos do Lado da Demanda}

\subsection{Definições e Considerações sobre Potenciais Energéticos}

Uma vez caracterizadas as dimensões e os atributos de análise de recursos energéticos, a terceira etapa do modelo consiste no cálculo dos potenciais energéticos e dos custos unitários de energia economizada.

A quantificação dos potenciais dos recursos de demanda permite apontar aqueles com maiores possibilidades reais de implantação, tanto a curto, quanto a médio e longo prazos, posto que apenas uma avaliação positiva nas dimensões de análise não é suficiente para estimar a disponibilização de um dado recurso e seu potencial de atendimento às necessidades energéticas da região estudada, tanto a médio como a longo prazo.

Para os potenciais, estima-se primeiramente potenciais totais de utilização de recursos, para em seguida limitá-los a valores de potenciais exeqüíveis de utilização. Assim, são calculados potenciais brutos ou teóricos, considerando, para cada recurso, parâmetros máximos de eficiência e possibilidades técnicas, geográficas e ambientais ilimitadas de utilização. Estes valores são então redimensionados, incorporando, desta vez, implicações de ordem técnica, econômica e ambiental relacionadas à utilização dos recursos. Este segundo potencial é chamado de potencial realizável, e busca indicar, de forma mais restrita, o potencial técnico-econômico de utilização de um determinado recurso, considerando também suas limitações de ordem ambiental.

Como terceiro módulo de processamento de potenciais energéticos, é inserido o potencial de mercado, o potencial energético esperado de um determinado recurso do lado da demanda dentro de perspectivas de mercado e 
condições dinâmicas de contorno como preços de energia, preferências do consumidor e políticas energéticas. Soma-se a estas condições a heterogeneidade de consumidores energéticos, nos diversos setores econômicos, contribuindo a uma percepção difusa quanto ao potencial de eficientização energética e sua mensuração. O potencial de mercado trabalha, portanto, com limitações sociais e políticas de recursos do lado da demanda, somadas a fatores dinâmicos de mercado.

Cabe ainda comentar que o potencial de mercado não necessariamente reduz o potencial realizável de um dado recurso; circunstâncias políticas e de mercado podem ampliar as perspectivas de implantação de uma medida de GLD em um dado período.

Desta forma, para o cálculo dos potenciais realizável e de mercado, temos, de um lado, valores brutos e, de outro, diversos fatores limitadores, correspondentes às quatro dimensões de análise. Cada um destes limitadores é responsável pela redução do potencial bruto em uma determinada fração. Porém, é comum haverem pontos de intersecção entre as diversas restrições distribuídas nas quatro dimensões, originando restrições híbridas, de ordem político-econômica, sócioambiental, entre outros tipos. Ao contemplar tais tipos de restrições nos cálculos, temos, como resultado, um produto final de limitações aplicáveis ao potencial bruto de valor diferente à somatória de fatores limitadores referentes a cada dimensão. Este produto final reduz o potencial bruto, moldando-o em potenciais realizável e de mercado.

Nos próximo ítens serão comentadas em maiores detalhes as restrições inerentes a cada tipo de recurso de GLD, bem como os algoritmos de cálculo de potenciais específicos a cada um deles. 


\subsection{Restrições aos Potenciais Energéticos}

As restrições ou limitações referentes aos potenciais energéticos de recursos do lado da demanda estão divididas em suas quatro dimensões de análise (ordem técnica, econômica, ambiental, social ou política) sendo norteadas basicamente pelos atributos de avaliação contidos nestas respectivas dimensões. No entanto, alguns atributos de teor essencialmente qualitativo, ou seja, de difícil mensuração numérica, não são considerados nos cálculos de potencial energético dos recursos.

Como algumas das restrições de ordem econômica para a mensuração do potencial energético de recursos de GLD, tem-se: o custo do empreendimento (programas ou tecnologias), o custo da energia economizada (que pode tanto ser positivo quanto negativo) e o tempo de retorno destes recursos e a possibilidade de incentivos tarifários como forma de estimular a adoção de programas ou tecnologias de controle de demanda. Estes fatores são essenciais para a viabilidade econômica de programas de GLD e podem, portanto, limitar de forma considerável ou mesmo definitiva o potencial realizável de um dado recurso.

No âmbito técnico, o potencial realizável de um recurso está condicionado basicamente aos seguintes limitadores: domínio tecnológico (representado pela detenção de uma base teórica e da capacitação profissional, treinamento e formação técnica, bem como a procedência do equipamento utilizado em uma dada ação de GLD), limitações de ordem geográfica (principalmente em função do clima), implicações quanto à qualidade da energia utilizada após a aplicação de medidas de GLD e principalmente a estrutura de marketing envolvida com determinados programas. 
Na dimensão ambiental, o cálculo do potencial realizável de recursos do lado da demanda pode sofrer restrições de acordo com o teor positivo ou negativo de impactos decorrentes da poluição atmosférica, da água e do solo.

Entre as restrições de ordem social capazes de limitar o potencial realizável de um recurso de GLD, pode-se mencionar: efeitos (negativos ou positivos) de alterações ambientais no meio social, impactos sociais positivos ou negativos decorrentes de tarifações diferenciadas por consumo, a tradição empresarial e residencial em relação a hábitos de consumo de energia e a influência de programas ou ações de GLD no desenvolvimento de atividades econômicas, comerciais, industriais e infra-Estrutura da região de aplicação.

Por último, temos a dimensão política, onde os atributos e possíveis limitadores do potencial energético são extremamente inexatos, ainda que cruciais para o desenvolvimento de políticas de GLD. Assim, dentre as mais importantes restrições temos: a aceitação ou rejeição a programas ou tecnologias de GLD (por parte dos diferentes En-In), o grau de apoio governamental (medido pela existência de mecanismos de incentivo ou implicações regulatórias) e o risco a exposição cambial, um atributo essencialmente político-econômico voltado aos casos de utilização de tecnologias importadas.

Dentre todos estes condicionadores, as imperfeições de mercado são basicamente moldadas por fatores como custos externos de energia, disponibilidade de capital para investimentos em recursos de GLD, subsídios, legislação vigente, tradição em relação a hábitos de uso de energia e motivações e tomada de decisões em residências e empresas [38]. Além destes fatores, o potencial de mercado considera a situação presente da região estudada, em termos de alternativas de 
gerenciamento de demanda e consumo energético a partir de tarifas alternativas, tanto para o setor residencial, quanto para os setores comercial e industrial.

Diversas indústrias, assim como empresas de médio investimento, comprometem-se apenas a tarefas imediatas de produção e gerenciamento; medidas de eficiência energética não constituem prioridade uma vez que muitas vezes representam uma pequena parcela nos custos energéticos da produção total ou do consumo residencial. Além disso, há limitações quanto ao levantamento de fundos para investimentos em medidas de eficiência, especialmente em condições de juros elevados, que direcionam consumidores a preferirem custos presentes mais altos a sujeitarem-se a créditos de maior duração. No caso de imóveis alugados, o estímulo a investir na melhoria da eficiência energética é baixo, tanto da parte dos locadores quanto dos proprietários, dada a incerteza de recuperação de investimentos considerando aumentos de aluguel.

Por fim, a falta de conhecimento técnico e informação de mercado acerca de possibilidades de eficiência energética por parte de consumidores residenciais, micro-empresários e pequenas e médias empresas representa um ponto extremamente negativo à difusão de ações de eficiência energética.

\subsection{Potenciais Energéticos e Custo da Energia Economizada de Recursos do Lado da Demanda}

Neste item, são exemplificados, para cada um dos grupos de recursos do lado da demanda, a mensuração do valor teórico de energia economizada e as possíveis restrições oriundas das quatro dimensões de análise. Esta conceituação permite demonstrar a metodologia de cálculo de potenciais energéticos e custos unitários de energia economizada dos recursos analisados. 


\subsubsection{Controle de Carga}

O controle de cargas através da utilização de diferentes equipamentos de controle é capaz de reduzir o consumo energético e evitar situações de sobrecarga na rede, por conta da utilização simultânea de equipamentos de uso final específicos. Neste caso, o potencial teórico de redução de demanda contemplará a utilização maciça de controladores na região de estudo considerada, bem como o maior número de aplicações simultâneas possível, tanto para o setor residencial quanto para o industrial e o comercial. O cálculo considera ainda índices máximos de redução de consumo. Para casos de deslocamento de carga a partir de controladores de demanda, o potencial energético não se aplica, posto que o consumo energético final permanece inalterado apesar de mudanças no perfil da curva de demanda.

Para a estimativa do potencial realizável, considera-se uma série de restrições detectadas nos setores industrial e comercial quanto à aplicação de controladores, por conta da usual regularidade das curvas de carga e a impossibilidade de interrupção dos processos de produção ou provisão de serviços realizados. A severidade destas restrições e a suposição de uma baixa adoção de controladores por parte da indústria determinam um potencial realizável que pode variar entre 10 e 50\% do valor teórico calculado.

Os cálculos de energia economizada consideram o capital empregado em dólares por meio da compra de equipamentos, software e custos de instalação e operação em função dos MWh economizados em um horizonte de tempo de utilização de tais equipamentos, estimado entre 10 e 20 anos. Novamente, em casos de deslocamento de demanda não é possível calcular a energia economizada uma vez que não são regsitradas alterações na mesma. 


\subsubsection{Substituição, Ajuste e Dimensionamento de Equipamentos}

Existem, neste caso, diversas medidas referentes à substituição de equipamentos obsoletos por tecnologias mais eficientes. Nos setores residencial e comercial, as principais áreas seriam de iluminação, condicionamento ambiental e refrigeração. O potencial teórico máximo possível seria obtido a partir da substituição integral de tecnologias antigas por atuais. Já no setor industrial uma grande porcentagem de consumo energético provém da utilização de motores. Pode-se atingir níveis razoáveis de economia a partir da alteração de diversos parâmetros de motores elétricos, ainda que o potencial de conservação mais elevado estaria em sua substituição por motores eficientes.

O cálculo do potencial teórico de economia energética para a substituição de equipamentos considera uma adoção integral de equipamentos eficientes, em qualquer que seja o setor de consumo estudado. Considera também, para tecnologias eficientes, índices máximos de redução energética estimados pelo Procel ou por estudos de conservação, que podem chegar a $40 \%$ de economia energética. Quando pertinente, são contempladas medidas diversas, como o ajuste de parâmetros de equipamentos, desde motores a ar condicionado, a substituição de peças, o controle de velocidade ou o retrofitting.

O potencial realizável contempla a aplicação destas medidas em uma porção restrita de estabelecimentos, considerada entre 10 e 30\% conforme as condições da área estudada, além de considerar índices mais conservadores para a redução de consumo energético, entre metade e um terço daqueles empregados no cálculo de potenciais brutos.

O custo de energia economizada contempla o custo empregado na substituição ou alteração de equipamentos em função da redução (em MWh) de 
consumo obtida com tais medidas durante o intervalo de tempo de utilizados e funcionamento adequado destes equipamentos, que pode variar entre 5 e 20 anos.

\subsubsection{Seleção e Substituição de Combustíveis}

Esta medida de GLD contempla a substituição de combustíveis fósseis (como diesel e gasolina) por combustíveis renováveis ou menos poluentes. Tal substituição está voltada primordialmente ao setor de transportes e à utilização de grupos geradores nos setores comercial e industrial. O objetivo de tal medida, contudo, não

é a redução do consumo ou da demanda energéticos, como em diversas outras aplicações de GLD, e sim a busca de benefícios de ordem ambiental, social, política e mesmo econômica. A utilização de combustíveis menos poluentes como o biodiesel, o álcool ou o gás natural representa ganhos de ordem ambiental e social, com a diminuição de impactos referentes à poluição atmosférica. Benefícios políticos e econômicos advêm da utilização de combustíveis provenientes de tecnologias nacionais e, portanto, menos vulneráveis a cenários econômicos internacionais. Como não é detectada para esta aplicação uma diferença de potencial energético de conservação, calculamos apenas o valor econômico gasto ou economizado com a substituição de combustíveis, expresso em US\$/MWh, a partir da diferença de litros consumidos de acordo com o poder calorífico de cada combustível e o rendimento dos motores utilizados.

A segunda medida de GLD é a eficientização de sistemas de combustão, entre eles motores, fornos e caldeiras, que podem ser redimensionados, modernizados ou convertidos para outro tipo de combustível. Esta medida resulta em impactos positivos tanto em termos técnicos, quanto econômicos (menores gastos energético) e ambientais, com a redução de emissões à atmosfera. 
Como terceira medida possível, pode-se recorrer à utilização de outros energéticos na provisão de usos finais como aquecimento de água e condicionamento ambiental, em substituição à energia provida pela rede elétrica. Tal medida, ainda que implique na redução do consumo de energia elétrica e conseqüentemente na diminuição da utilização da rede, traz diferentes impactos nas dimensões de análise. Desta forma, obtêm-se uma redução na curva de carga, ainda que gastos referentes a outros equipamentos e combustíveis possam ser consideráveis.

Há, portanto, três diferentes medidas possíveis para este recurso do lado da demanda. Para casos de substituição de combustíveis veiculares, o cálculo de potenciais energéticos ou de custos de energia economizada não se aplica. Para a eficientização de sistemas de combustão, o potencial teórico é calculado, analogamente aos casos anteriores, considerando potenciais de conservação máximos para tal medida, entre 30 e 40\%. Estimando uma penetração de medidas de eficientização de caldeiras, retroffiting ou adequação de práticas de manutenção entre 10 e 50\% dos índices estimados no cálculo do potencial teórico, obtém-se o valor do potencial realizável. O custo de tais medidas segue o procedimento dos recursos anteriores, calculando-se a razão entre o investimento feito com a aquisição ou reforma de estruturas ou equipamentos pelo montante de energia economizada durante sua vida útil ou até as seguintes reformas ou ajustes.

Já para a utilização de equipamentos movidos a outros combustíveis, em substituição à rede, pode-se calcular o custo de energia economizada a partir do investimento em equipamentos como coletores solares ou ar condicionado a gás natural em função da quantidade de energia decrescida da rede elétrica, dentro de um determinado horizonte de tempo de utilização destes equipamentos. 


\subsubsection{Projetos Eficientes de Edificações}

A partir da utilização de preceitos da arquitetura bioclimática, é possível realizar projetos de edificações energeticamente eficientes, aproveitando de forma racional elementos naturais como a iluminação solar e a ventilação. A partir do uso eficiente de uma concepção e disposição eficientes de janelas e aberturas superiores e laterais, é possível aproveitar grande parte da iluminação natural (durante o dia) e da ventilação, reduzindo consideravelmente o consumo energético referente aos usos finais de iluminação e condicionamento ambiental, substanciais nos setores residencial e comercial.

O cálculo do potencial energético teórico para este recurso contempla a utilização de projetos eficientes em todas as edificações da região focada, tanto residências, como estabelecimentos comerciais e indústrias. São utilizados índices otimistas de redução energética a partir do emprego de tais medidas. Sabe-se, no entanto, que a potencial aplicação de preceitos de eficiência energética em projetos para casas, edifícios e construções ocorre apenas em casos de reformas ou novas construções. Desta forma, o potencial realizável de redução de demanda energética é calculado apenas a partir da possibilidade de novas construções (baseada no crescimento econômico e demográfico da região de estudo) ou de reformas em edificações, considerando para tanto, índices mais moderados de redução de demanda energética.

A energia economizada a partir de tais projetos seria obtida essencialmente a partir da redução da iluminação artificial. Assim, o potencial teórico seria obtido considerando-se a projetos que eliminassem ou reduzissem ao máximo a utilização da iluminação artificial durante o dia. O potencial realizável estimaria a incorporação 
de tais projetos em uma porção discreta de estabelecimentos, entre 10 e 20\%, considerando uma redução da utilização de luz artificial em valores moderados, também entre 10 e $20 \%$.

O exercício da estimativa do custo da energia economizada torna-se difícil de ser quantificado para este recurso, uma vez que os projetos e reformas executados variam de acordo com uma série de parâmetros como características do edifício ou residência construída ou modificada, extensão da reforma realizada, tipos de

materiais empregados, entre diversos outros. Assim, para este recurso, o procedimento para o cálculo do custo de energia economizada não se aplica; custos acerca do projeto e reformas executadas são diretamente derivados de cada projeto executado. Cabe mencionar, porém, que existem softwares dedicados à simulação e ao cálculo da conservação energética em projetos de arquitetura bioclimática.

\subsubsection{Tarifação e Regulação}

É sabido que o uso de diferentes modalidades tarifárias, promovido por medidas de regulação, é capaz de estimular o uso racional de energia e disciplinar hábitos de consumidores, não apenas residenciais, como também grandes consumidores do setor industrial. Sendo assim, o potencial teórico de redução de consumo e demanda energéticas contempla o uso deste tipo de tarifas pela totalidade de consumidores da região de estudo, estipulando previsões de consideráveis reduções porcentuais de demanda. Já para o potencial realizável, considera-se a adoção moderada de consumidores a tarifas alternativas, bem como metas modestas de redução de demanda energética. Em ambos os casos, parte-se de valores estimados de redução de demanda para cada tipo de tarifa, obtendo uma previsão de redução média. Para o potencial teórico, contemplaremos as melhores 
opções de tarifas, ainda que não implantadas nacionalmente. Já para o potencial realizável, são consideradas apenas as opções presentes em termos de tarifas.

Quanto à regulação, ainda que medidas governamentais e de agentes relacionados sejam importantíssimas na promoção do GLD, a aferição do potencial de conservação energética por meio destas políticas é extremamente inexata e imprecisa, permanecendo portanto no campo conceitual.

A adoção de tarifas diferenciadas pode contribuir para o deslocamento da demanda ou para a redução do consumo energético. No primeiro caso, o potencial energético e os custos de energia economizada não se aplicam, uma vez que a energia total consumida permanece inalterada. No segundo caso, o potencial de redução energética é extremamente suscetível a características da tarifa aplicada, como preços por blocos ou variação de cobrança por horário. Desta forma o cálculo do potencial para este recurso não possui um padrão definido, seguindo uma abordagem particularizada para cada tipo de tarifa analisado.

\subsubsection{Armazenamento de Energia}

O armazenamento de energia, ou a produção de frio ou calor e seu armazenamento em termoacumuladores para utilização posterior, constitui uma medida eficaz de GLD, na medida em que pode reduzir a demanda energética do sistema e recortar picos da curva de carga, deslocando-os para períodos de baixa utilização energética. Tal recurso pode ter ampla aplicação, principalmente nos setores residencial e comercial, onde os usos finais de aquecimento de água e condicionamento ambiental são responsáveis por uma parcela considerável do consumo energético. O armazenamento de energia seria responsável, assim, por deslocar parte da demanda em horários de pico a horários alternativos. Eliminando ou reduzindo o consumo energético na ponta e uniformizando a curva de carga, 
pode-se obter ganhos econômicos consideráveis na fatura de eletricidade, reduzindo-se o consumo no horário de ponta ou mesmo a demanda contratada.

Ainda que seja possível obter uma economia referente a gastos mensais de tarifa, deve-se ressaltar que o armazenamento de energia não provoca qualquer tipo de alteração ao potencial energético de conservação de um dado uso final, na medida em que apenas provoca modificações na topologia da curva sem, contudo, interferir na quantidade de consumo energético. Desta forma, o potencial de redução de demanda energética e o custo da energia economizada não são calculados para este recurso.

\subsubsection{Programas de Informação e Educação}

Para este recurso são relacionados programas e campanhas de informação e educação quanto ao uso racional e consciente de energia elétrica. São considerados tanto programas realizados em escolas de ensino básico e médio, disciplinas em universidade e cursos de capacitação e profissionalização tanto para docentes quanto para a formação de especialistas na área. Para os setores comercial e industrial, pode-se considerar workshops e oficinas localizadas, para funcionários e empregadores de estabelecimentos e fábricas.

Obviamente, a quantificação do potencial de conservação energética advindo deste recurso de GLD é de mensuração extremamente complexa e inexata. Entretanto, pretende-se estimar, para a região de estudo, qual seria o potencial de redução energética esperado, considerando-se valores per capita médios, obtidos tanto em estudos internacionais quanto em índices aproximados do PROCEL.

Assim, para o cálculo do potencial teórico são considerados programas que abrangessem a integralidade da população, obtendo portanto um potencial máximo de redução energética. Para o potencial realizável, são adotados valores realistas de 
conservação energética per capita, além de uma porção restrita de escolas, estabelecimentos e população em geral como abrangidos por programas e campanhas. Desta forma, o valor final do potencial de conservação obtido é a princípio consideravelmente realista.

Assim, para o cálculo do potencial teórico são considerados programas que abranjam a integralidade da população, bem como índices per capita de perspectivas de redução energética obtidos de estudos nacionais (como relatórios de resultados do Procel) ou artigos internacionais. Para o potencial realizável, são adotados índices mais moderados de conservação energética per capita, entre 10 e 50\% dos valores utilizados para o cálculo do potencial teórico. É também considerada uma porção restrita de escolas, estabelecimentos e população em geral como abrangidos por programas e campanhas.

O cálculo do custo de energia economizada não se aplica neste caso, posto que a mensuração dos recursos empregados em tais programas é extremamente inexata e não necessariamente repercute nas metas desejadas de redução de consumo de energia. 


\section{Aplicação Real do Modelo em Estudo de Caso em Araçatuba}

A fim de consolidar, de forma pratica, a Metodologia de Caracterização e Análise de Recursos Energéticos, a parte final da dissertação pretende aplicar o Modelo de Caracterização em um estudo de caso real, na Região Administrativa de Araçatuba. Para tanto, são utilizadas ferramentas consolidadas do PIR, como a Avaliação de Custos Completos (ACC), o Cálculo de Potenciais e a Elaboração de Cenários Energéticos voltados à Projeção de Demanda Local e à inserção gradual de medidas de GLD, em intervalos determinados de tempo. Os cenários considerados são de perfil conservador (Business As Usual, ou seja, a previsão da evolução da demanda considerando a manutenção dos atuais parâmetros de consumo e eficiência energética), realizável (estimando parâmetros factíveis de eficiência energética ao longo do horizonte de análise) e sustentável (contemplando o desenvolvimento e a adoção maciça de recursos de GLD e um aumento considerável de eficiência energética).

Assim, a proposta do Estudo de Caso é de elaborar uma carteira de recursos do lado da demanda, para a região de Araçatuba, por meio de um exercício acadêmico baseado em dados reais [39] no qual é proposto um plano preferencial de integração do GLD dentro dos próximos trinta anos, representado em cenários conservadores, realizáveis e sustentáveis.

A primeira etapa do Estudo de Caso é o levantamento de recursos de GLD presentes na região focada, bem como o estudo da possibilidade de inserção de outros programas e tecnologias na região em um momento futuro. Todos estes recursos são discriminados e organizados em grupos descritos no Capítulo 4 e são submetidos a uma triagem, visando selecionar para a análise apenas um número determinado de recursos aptos de adoção (no presente ou em um momento futuro) 
na região de estudo. Os recursos selecionados são então analisados dentro das quatro dimensões descritas anteriormente.

Assim, na segunda etapa, ocorre a Avaliação de Custos Completos (ACC), na qual são levantados todos os custos (ou impactos positivos e negativos) referentes aos recursos de GLD relacionados na etapa anterior. Nesta avaliação, impactos técnico-econômicos são alocados conjuntamente com impactos de ordem ambiental, social e política. A contabilização de todos os custos e benefícios tanto para o meio ambiente, quanto para a economia e para a sociedade como um todo, resulta no custo completo de cada recurso do lado da demanda. Quanto menor o custo completo de um recurso, menores os seus impactos negativos de ordem geral. Ainda que diversos impactos externos (principalmente referentes a efeitos da atividade energética nos campos sociais e políticos) não possam ser quantificados com precisão, estes recebem uma avaliação de ordem qualitativa.

Após a ACC, procede-se à terceira etapa, na qual são calculados os potenciais energéticos dos recursos. Esta etapa contempla estimativas de potenciais energéticos totais de cada recurso do lado da demanda (potencial teórico e irrestrito, sem limitações de técnicas, econômicas ou geográficas de utilização), e potenciais realizáveis ou factíveis de utilização (considerando diversas restrições de ordem técnica, econômica, social, política e ambiental, explicitadas anteriormente).

Como etapa final, são produzidos cenários contemplando a evolução local da demanda considerando, obviamente, a possível inserção de recursos de GLD, em intervalos regulares de tempo, em um horizonte de médio prazo.

Cabe mencionar, que este modelo, agregado ao Modelo de Caracterização de Oferta Energética compõe uma parcela inicial do PIR, na qual recursos energéticos são avaliados de forma integrada (opções de demanda são consideradas em termos 
iguais a opções de oferta energética) de forma a compor a melhor combinação energética capaz de atender, de forma sustentável, às necessidades energéticas da região estudada, tanto a médio como a longo prazo.

\subsection{Região Administrativa de Araçatuba}

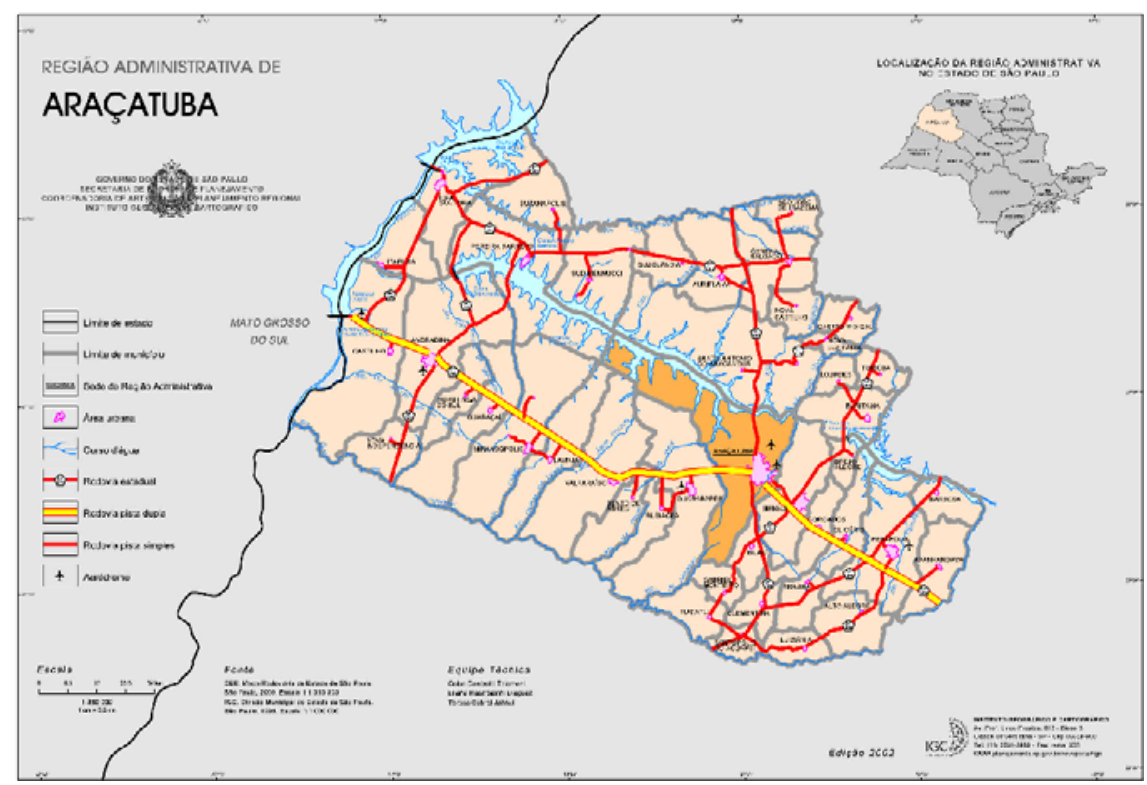

Figura 7.1: Região Administrativa de Araçatuba

A Região Administrativa de Araçatuba é objeto deste estudo de caso, uma vez que nesta região foi realizado um exercício preliminar de PIR em 2004, com o apoio da FAPESP e da organização não-governamental Cooperhidro [39]. Tal exercício envolveu o levantamento de dados relacionados à oferta e ao consumo de energia, principalmente nos setores industrial e agropecuário locais. Estes dados foram levantados a partir da elaboração de questionários voltados aos principais envolvidos e interessados na questão energética regional.

A região administrativa de Araçatuba possui uma área de $18.588 \mathrm{~km}^{2}(7,48 \%$ do total do estado), situa-se no Noroeste do estado, e é constituída por 43 municípios, compreendendo duas regiões de governo, Andradina e Araçatuba. 
Dispõe de uma posição privilegiada no que diz respeito ao comércio, graças à multimodalidade no transporte de mercadorias, através do porto hidroviário, a Rodovia Marechal Rondon, um ramal ferroviário da Novoeste (Ferronorte), recentemente operado pela iniciativa privada, e a existência de um pólo gerador de energia hidrelétrica, que também amplia as possibilidades de expansão econômica na região [39].

Com uma população de 697.980 habitantes em 2004, a região representa cerca de $2 \%$ do total da população do Estado, com uma baixa densidade demográfica, de 37,55 habitantes por $\mathrm{km}^{2}$, em 2004. Dentro da Região de Araçatuba, os quatro municípios mais populosos - Andradina, Araçatuba, Birigüi e Penápolis - representam 55\% do total da população regional. As taxas populacionais indicam que há uma tendência ao esvaziamento da região, comparada ao conjunto do Estado.

O valor adicionado fiscal da RA em 1999 foi de R\$ 3,19 bilhões, o que representa um acréscimo de $6,19 \%$ sobre o ano anterior e uma redução na participação do valor adicionado estadual de 1,65\% em 98 para 1,59\% em 1999 [40]. Os municípios de Araçatuba, Ilha Solteira, Castilho, Pereira Barreto, Andradina e Penápolis somados representam $72 \%$ do valor adicionado regional, indicando uma forte concentração de geração de valor adicionado em poucos municípios [40].

A atividade de geração de energia elétrica representa, individualmente, $38,69 \%$ do valor adicionado fiscal gerado em 97 . Em seguida destacam-se as atividades industriais, com $33,4 \%$ do total do valor adicionado gerado em 1997 . O setor agroindustrial, como um todo, inclui empresas frigoríficas, álcool e açúcar, massas e polpas de frutas, processamento de leite em pó, curtimento de couro, 
indústria de calçados, desidratação de ovos, entre outras, concentradas em Araçatuba, Birigüi, Penápolis e Andradina [40].

A agroindústria é o segmento mais representativo da atividade industrial, principalmente no que se refere às atividades relacionadas ao álcool e à pecuária de corte: a indústria de bebidas, líquidos alcoólicos e vinagre representa 9,18\% do valor adicionado regional. Um grande grupo, que agrega a indústria de produtos alimentícios de origem animal e indústrias diversas, representa $6,69 \%$ do total do valor adicionado, sendo $6,36 \%$ referente a frigoríficos. Do ponto de vista individual, a indústria de frigoríficos é o setor desta região que mais se destaca na economia do Estado, representando $11 \%$ do valor adicionado fiscal estadual do setor, em 97 [40].

\subsection{Recursos Selecionados}

Os sete grandes grupos de ações energéticas do lado da demanda podem ser ramificados em inúmeras possibilidades de recursos. Destes, foram selecionados nove recursos principais, a partir de variados critérios como aplicabilidade local, relevância em termos de eficiência energética e principalmente diversidade e abrangência de medidas de gerenciamento do lado da demanda. Desta forma, foram selecionados, como recursos do lado da demanda elétrica: controladores de demanda, eficientização de motores elétricos, refrigeração, iluminação, adoção de tarifas para blocos de consumo e acumulação de frio. Como recursos de gerenciamento da demanda energética foram selecionados a eficientização de sistemas de combustão (fornos e caldeiras) e a substituição de diesel por gás natural veicular em transportes de uso interno na indústria. Como último recurso, foi ainda incluída a adoção de projetos bioclimáticos de edificações, que envolve basicamente a eficientização da iluminação e do condicionamento ambiental internos. 


\subsection{Avaliação dos Custos Completos}

Feito o levantamento e a seleção de recursos analisados de acordo com critérios básicos de potencial de aplicação e/ou diversidade de ações de GLD, foi então realizada a Avaliação dos Custos Completos. A ACC foi realizada de forma a abranger todo o período de análise; desta forma temos resultados para o instante presente de análise (2005), para os anos de 2015, 2025 e, como instante final deste estudo, 2035.

A avaliação dos recursos selecionados ocorreu em diversos atributos dentro das quatro dimensões de análise. Os atributos também foram pré-selecionados antes da análise, de acordo com sua adequação aos recursos avaliados. A cada dimensão foi atribuído o mesmo peso relativo; dentro de cada grupo, contudo, foram atribuídos diferentes pesos para cada fator, proporcionalmente à sua importância relativa.

Com os resultados da ACC é possível classificar as alternativas avaliadas de acordo com as notas obtidas. É importante destacar, de todo modo, que esta classificação é indicativa, além de não-restritiva. Ou seja, uma boa classificação do recurso não garante que ele seja usado com exclusividade; isto se deve a restrições impostas por fatores que não são alvo da ACC, mas que devem ser considerados nas etapas posteriores do PIR.

A Avaliação dos Custos Completos integral, com a discriminação de todos os atributos e respectivas pontuações pode ser vista no Anexo. Já os resultados finais da avaliação nos referidos instantes temporais podem ser vistos nas tabelas a seguir. 
Tabela 7.3.1. ACC 2005

\begin{tabular}{|l|c|c|c|c|c|}
\hline Recursos/Dimensões & $\begin{array}{c}\text { Técnico- } \\
\text { Econômica }\end{array}$ & Ambiental & Social & Política & $\begin{array}{c}\text { Pontuação } \\
\text { Final }\end{array}$ \\
\hline Controlador de Demanda & 6,0417 & 5,0000 & 2,5000 & 1,2500 & $\mathbf{3 , 6 9 8}$ \\
\hline Iluminação & 4,5536 & 0,8333 & 3,7500 & 5,9375 & $\mathbf{3 , 7 6 9}$ \\
\hline $\begin{array}{l}\text { Uso Eficiente de Motores } \\
\text { Elétricos }\end{array}$ & 4,9107 & 5,0000 & 7,5000 & 6,2500 & $\mathbf{5 , 9 1 5}$ \\
\hline Refrigeração Eficiente & 5,8036 & 5,0000 & 5,0000 & 6,2500 & $\mathbf{5 , 5 1 3}$ \\
\hline $\begin{array}{l}\text { Substituição de } \\
\text { (Vombustíveis } \\
\text { Veicular: Diesel por GNV) }\end{array}$ & 8,4211 & 6,6667 & 6,2500 & 1,6667 & $\mathbf{5 , 7 5 1}$ \\
\hline $\begin{array}{l}\text { Eficientização de Sistemas } \\
\text { de Combustão }\end{array}$ & 4,3478 & 6,6667 & 7,5000 & 6,2500 & $\mathbf{6 , 1 9 1}$ \\
\hline $\begin{array}{l}\text { Tarifas Alternativas } \\
\text { Projetos Eficientes de }\end{array}$ & 4,0476 & 5,0000 & 2,5000 & 2,1875 & $\mathbf{3 , 4 3 4}$ \\
\hline $\begin{array}{l}\text { Edificações } \\
\text { (Termazenamento de Energia }\end{array}$ & 3,7500 & 5,0000 & 2,5000 & 1,2500 & $\mathbf{3 , 0 7 3}$ \\
\hline
\end{tabular}

Tabela 7.3.2. ACC 2015

\begin{tabular}{|l|c|c|c|c|c|}
\hline Recursos/Dimensões & $\begin{array}{c}\text { Técnico- } \\
\text { Econômica }\end{array}$ & Ambiental & Social & Política & $\begin{array}{c}\text { Pontuação } \\
\text { Final }\end{array}$ \\
\hline Controlador de Demanda & 6,2500 & 5,0000 & 5,0000 & 5,0000 & $\mathbf{5 , 3 1 3}$ \\
\hline Iluminação & 5,9821 & 0,8333 & 3,7500 & 7,5000 & $\mathbf{4 , 5 1 6}$ \\
\hline $\begin{array}{l}\text { Uso Eficiente de Motores } \\
\text { Elétricos }\end{array}$ & 5,8036 & 5,0000 & 7,5000 & 8,3333 & $\mathbf{6 , 6 5 9}$ \\
\hline Refrigeração Eficiente & 5,9821 & 5,0000 & 5,0000 & 8,3333 & $\mathbf{6 , 0 7 9}$ \\
\hline $\begin{array}{l}\text { Substituição de } \\
\text { Combustíveis } \\
\text { (Veicular: Diesel por GNV) }\end{array}$ & 9,4737 & 6,6667 & 8,7500 & 5,0000 & $\mathbf{7 , 4 7 3}$ \\
\hline $\begin{array}{l}\text { Eficientização de Sistemas } \\
\text { de Combustão }\end{array}$ & 5,3261 & 6,6667 & 7,5000 & 8,3333 & $\mathbf{6 , 9 5 7}$ \\
\hline $\begin{array}{l}\text { Tarifas Alternativas } \\
\text { Projetos Eficientes de } \\
\text { Edificações }\end{array}$ & 7,8810 & 5,0000 & 2,5000 & 2,1875 & $\mathbf{3 , 6 4 2}$ \\
\hline $\begin{array}{l}\text { Armazenamento de Energia } \\
\text { (Termoacumulação) }\end{array}$ & 5,3125 & 5,0000 & 5,0000 & 4,0625 & $\mathbf{4 , 8 4 4}$ \\
\hline
\end{tabular}


Tabela 7.3.3. ACC 2025

\begin{tabular}{|c|c|c|c|c|c|}
\hline Recursos/Dimensões & $\begin{array}{l}\text { Técnico- } \\
\text { Econômica }\end{array}$ & Ambiental & Social & Política & $\begin{array}{l}\text { Pontuação } \\
\text { Final }\end{array}$ \\
\hline Controlador de Demanda & 8,3333 & 5,0000 & 6,2500 & 5,6250 & 6,302 \\
\hline lluminação & 7,5893 & 2,5000 & 3,7500 & 8,7500 & 5,647 \\
\hline $\begin{array}{l}\text { Uso Eficiente de Motores } \\
\text { Elétricos }\end{array}$ & 7,9464 & 5,0000 & 7,5000 & 9,1667 & 7,403 \\
\hline Refrigeração Eficiente & 7,7679 & 5,0000 & 6,2500 & 9,1667 & 7,046 \\
\hline $\begin{array}{l}\text { Substituição de } \\
\text { Combustíveis } \\
\text { (Veicular: Diesel por GNV) }\end{array}$ & 10,0000 & 6,6667 & 8,7500 & 6,8750 & 8,073 \\
\hline $\begin{array}{l}\text { Eficientização de Sistemas } \\
\text { de Combustão }\end{array}$ & 7,6087 & 6,6667 & 7,5000 & 9,1667 & 7,736 \\
\hline Tarifas Alternativas & 6,9048 & 5,0000 & 3,7500 & 6,0938 & 5,437 \\
\hline $\begin{array}{l}\text { Projetos Eficientes de } \\
\text { Edificações }\end{array}$ & 8,8462 & 5,0000 & 6,2500 & 6,4583 & 6,639 \\
\hline $\begin{array}{l}\text { Armazenamento de Energia } \\
\text { (Termoacumulação) }\end{array}$ & 7,9167 & 5,0000 & 6,2500 & 5,1563 & 6,081 \\
\hline
\end{tabular}

Tabela 7.3.4. ACC 2035

\begin{tabular}{|c|c|c|c|c|c|}
\hline Recursos/Dimensões & $\begin{array}{l}\text { Técnico- } \\
\text { Econômica }\end{array}$ & Ambiental & Social & Política & $\begin{array}{l}\text { Pontuação } \\
\text { Final }\end{array}$ \\
\hline Controlador de Demanda & 8,3333 & 5,0000 & 7,5000 & 7,5000 & 7,083 \\
\hline Iluminação & 7,9464 & 5,0000 & 5,0000 & 10,0000 & 6,987 \\
\hline $\begin{array}{l}\text { Uso Eficiente de Motores } \\
\text { Elétricos }\end{array}$ & 8,3036 & 5,0000 & 7,5000 & 10,0000 & 7,701 \\
\hline Refrigeração Eficiente & 7,7679 & 5,0000 & 7,5000 & 10,0000 & 7,567 \\
\hline $\begin{array}{l}\text { Substituição de } \\
\text { Combustíveis } \\
\text { (Veicular: Diesel por GNV) }\end{array}$ & 10,0000 & 6,6667 & 10,0000 & 8,7500 & 8,854 \\
\hline $\begin{array}{l}\text { Eficientização de Sistemas } \\
\text { de Combustão }\end{array}$ & 7,6087 & 6,6667 & 7,5000 & 9,7917 & 7,892 \\
\hline Tarifas Alternativas & 6,9048 & 5,0000 & 5,0000 & 7,5000 & 6,101 \\
\hline $\begin{array}{l}\text { Projetos Eficientes de } \\
\text { Edificações }\end{array}$ & 8,8462 & 5,0000 & 7,5000 & 6,6667 & 7,003 \\
\hline $\begin{array}{l}\text { Armazenamento de Energia } \\
\text { (Termoacumulação) }\end{array}$ & 7,9167 & 5,0000 & 7,5000 & 6,5625 & 6,745 \\
\hline
\end{tabular}




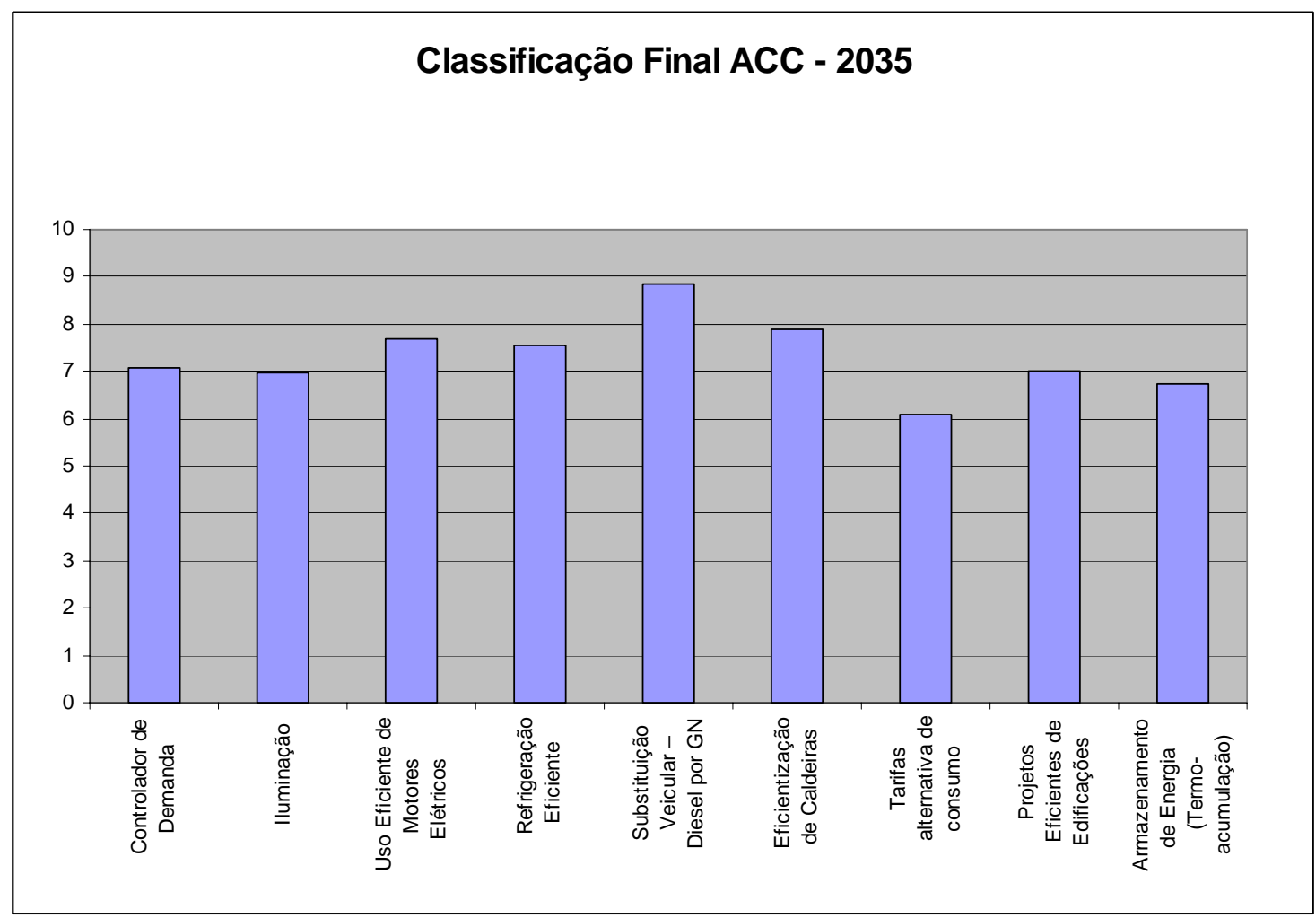

Figura 7.3. Classificação Final ACC -2035

Os resultados da avaliação seguem um padrão específico semelhante para os quatro instantes temporais considerados. As dimensões técnico-econômica e ambiental sofreram menores alterações ao longo do horizonte de análise, ao passo em que as dimensões social e política incorporaram hipotéticas transformações em termos de adoção e conscientização acerca do uso racional de energia e de um maior apoio governamental a políticas de GLD.

Para o momento presente, foram consideradas circunstâncias conservadoras à implantação e difusão de recursos do lado da demanda, tanto acerca de aspectos técnicos, quanto do reconhecimento da sociedade e dos En-In. Assim, os resultados mostram, para o horizonte final da análise, o uso de motores eficientes e a substituição de Diesel por GNV no uso veicular interno no setor industrial, como recursos mais competitivos, por conta de vantagens técnico-econômicas como eficiência e tempo de retorno, bem como poucos entraves de ordem social, como a difusão e a compreensão de usuários acerca dos recursos e de seu benefícios. 
Como recursos desfavoráveis no instante inicial, estão as tarifas alternativas e o controlador de demanda, acompanhados do armazenamento de energia. Tal posição deve-se essencialmente a obstáculos sociais e políticos presentes, como a falta de apoio governamental a reais medidas de gerenciamento da demanda, e à pequena estrutura de disseminação de informação atrelada a tais recursos.

Já para o instante final de análise, a substituição de Diesel por GNV no uso veicular e o Uso Eficiente de Motores Elétricos continuam adiante na classificação final da ACC, acompanhados pela eficientização de Sistemas de Combustão, mais especificamente de caldeiras. Tal resultado deve-se basicamente à implantação e consolidação destas medidas como alternativas de eficientização energética desde o momento presente, a fatores técnicos e econômicos favoráveis, a uma boa aceitação social dos recursos e a um bom índice de compreensão e utilização do recurso por parte dos consumidores industriais.

No outro extremo da classificação, estão as tarifas alternativas de consumo e armazenamento de energia como recursos que apresentaram obstáculos de ordem social e política, com perspectivas moderadas de aceitação e adoção por parte de consumidores, e de ordem econômica, no caso de tarifas alternativas, dada a baixa viabilidade de implantação de tarifas noturnas no setor industrial.

\subsection{Cálculo dos Potenciais Energéticos}

São calculados neste estudo de caso, os potenciais teórico e realizável dos recursos selecionados. Para o potencial teórico é considerado um índice máximo de economia energética de um dado recurso, a partir de índices acordados de eficiência energética de cada medida. O potencial realizável, derivado dos valores teóricos, é estimado a partir de restrições de ordem técnica, econômica e ambiental. Neste 
estudo de caso não foi calculado o potencial de mercado; para o mesmo seria necessário um acompanhamento intensivo e rigoroso das condições de mercado locais, bem como a percepção constante de todos os envolvidos e interessados e da sociedade como um todo em relação aos recursos energéticos do lado da demanda. Esta percepção é tecnicamente inviável de ser colhida uma vez que alguns dos recursos selecionados para o estudo de caso não estão atualmente em aplicação na região, impossibilitando a análise.

Foram considerados, para os cálculos, que o setor industrial consome em energia um total de 73.092 toneladas equivalentes de petróleo, sendo 14.628 tep, ou 201,633 GWh, por parte da energia elétrica [40]. Considerando a indústria de alimentos, bebidas e frigoríficos como responsável por dois terços do valor adicionado da região administrativa de Araçatuba, e dada a inexistência de indústrias eletrointensivas na região, foi adotada uma aproximação do setor industrial local ao perfil de consumo da indústria de alimentos. Desta forma, foi estimado que $80 \%$ da eletricidade consumida pelo setor é destinada a processos, sendo 50\% consumido por motores elétricos e 30\% em refrigeração [41]. Outros 16\% de eletricidade vão para usos finais que não fazem parte de processos, como aquecimento, ventilação, condicionamento ambiental e iluminação. Para este último uso final foi considerada uma participação de 5\% [41].

Em relação a outros energéticos, foi considerado o consumo de óleo combustível e biomassa para fornos e caldeiras e Diesel para uso veicular interno. Foi estimado que caldeiras consomem cerca de um terço da energia total da indústria, ou um total de 24.364 tep. Metade da energia total de uso final é destinada ao processamento de alimentos, sendo $30 \%$ consumida pelo calor em processos e 15\% pela refrigeração em processos [41]. A energia remanescente é utilizada em 
usos externos a processos, como o aquecimento, a ventilação e a iluminação das instalações, além da geração de energia elétrica e o transporte interno de veículos.

A seguir, é descrito o procedimento de cálculo do potencial energético e custos de energia economizada dos recursos analisados.

\subsubsection{Controlador de Demanda}

Foi estimado um translado de $20 \%$ da carga de demanda no horário comercial, remanejado para o período noturno. Este valor foi estipulado através de estudos conduzidos por Januzzi [36], acerca da viabilidade de se deslocar parte da produção diurna para o período noturno, em termos de custos adicionais de mão de obra, estoque e área construída. Considerando uma demanda elétrica de cerca de $90 \mathrm{MW}$ na região, seriam deslocados aproximadamente $18 \mathrm{MW}$ deste total. O custo médio desta ação está em 45 mil dólares, incluindo software e hardware, de acordo com levantamento realizado a partir da homepage da Rockwell [43]. Desta forma o custo de implantação, considerando a utilização desta estrutura em um horizonte de tempo de 10 anos, está na faixa de US\$250/MW.

Contudo, esta ação modifica apenas a demanda energética e não é capaz de alterar o potencial de conservação energética de indústrias. Assim, não cabe neste caso o cálculo dos potenciais energéticos ou da energia economizada.

\subsubsection{Motores Elétricos}

Considera-se para este recurso, parâmetros médios de 50\% de participação de motores elétricos na indústria, ou um total de eletricidade de 100,8 GWh. O potencial teórico de economia de energia seria o acúmulo de duas medidas: troca de motor padrão por motor eficiente ao final da vida útil e aplicação de controladores de velocidade. A primeira medida, estudada por Tolmasquim [29], é capaz de gerar uma 
redução de 5\% no consumo de eletricidade, a um custo de energia economizada de US\$17/MWh. Já o controle de velocidade é capaz de alcançar uma média de 20\% de economia energética, de acordo com [33] a um custo médio de US\$10,00 /MWh. Desta forma o custo total de energia economizada está em torno de 25 US\$/MWh, e o potencial teórico, de 25\% de redução de consumo é estimado em 25,2 GWh/ano. O potencial realizável contempla a aplicação de medidas de eficientização em apenas $30 \%$ dos motores industriais em atividade, gerando uma economia conservadora de $10 \%$ da energia consumida por este uso final. Desta forma, o potencial realizável é de 3,02 GWh.

\subsubsection{Refrigeração}

O uso final de refrigeração foi apontado como consumidor de $30 \%$ da energia elétrica industrial da região, ou 60,5 GWh. Tal consumo pode ser reduzido em $40 \%$ a partir da utilização de controladores de velocidade, de acordo com [33]. Desta forma, para um sistema de 60,6 GWh, obtêm-se um Potencial Teórico de 24,2 GWh/ano. Considerando uma adoção de tais medidas em uma fração de 25\% das indústrias da região, gerando uma redução energética mais moderada, de 20\%, o potencial prático resultante é de 1,21 GWh.

Para este mesmo sistema de 60,6 GWh, funcionando a 6000 horas/ano, a capacidade total seria de 10,1 MW. O custo adotado de US\$150/MW [33] resulta em um investimento de cerca de US\$1,5 milhão, para um horizonte de 15 anos. O custo total de energia economizada fica, portanto numa faixa entre 5 e 10 US\$/MWh, para economias energéticas anuais de 20 e 10 GWh, respectivamente. 


\subsubsection{Iluminação}

A iluminação responde por $5 \%$ do consumo energético do setor industrial local (valor médio dentro da faixa de 2 a $7 \%$ obtida). Considerando um consumo do setor de 10,1 GWh e uma utilização de 2500 horas por ano, tem-seuma demanda de 4000 kW. Um exemplo industrial [45] considerando a substituição de 175 luminárias incandescentes de $750 \mathrm{~W}$ por lâmpadas de metal halide de $250 \mathrm{~W}$ pode gerar uma economia de $40 \%$ no consumo energético. Tal consumo evitado, para uma utilização anual de 3000 horas seria igual a 4800 MWh. Partindo de um custo de investimento de US\$750.000 para uma vida útil de 8 anos deste sistema de iluminação, o custo total de energia economizada fica em 20,03 US\$/MWh. A utilização de sistemas eficientes de iluminação, ao reduzir o consumo estimado em 40\%, geraria um potencial teórico de 4,04 GWh/ano. Se a substituição for praticada em apenas um quarto das indústrias locais e a real economia energética obtida for de $20 \%$, produzse um potencial realizável de 0,505 GWh/ano.

\subsubsection{Adoção de Tarifas Alternativas}

Há uma série de possibilidades de tarifas a serem futuramente implantadas em âmbito nacional e adotadas no setor industrial. Algumas delas foram discutidas no item 4.3.5. Para este estudo de caso consideramos a opção da tarifa com preço diferenciado durante a madrugada, estudada por Januzzi [36]. Esta tarifa, apesar de deslocar a demanda para horários não comerciais, reduzindo a fatura energética de indústrias, não altera o consumo total de eletricidade. Desta forma tanto o potencial energético, quanto o custo de energia economizada não se aplicam neste caso.

Em termos de economia na fatura final de eletricidade, simulações realizadas por [36] que prevêem um desconto de $15 \%$ no valor da tarifa noturna (entre $22 \mathrm{hs}$ e 6hs), calculam um deslocamento de $25 \%$ do consumo diurno para o horário da 
madrugada. Tal alteração na curva de demanda resultaria em valores médios de 5\% de economia no valor da tarifa de eletricidade. Em contrapartida, os custos do empreendimento seriam extremamente elevados, dado o alto valor do deslocamento da produção e da mão de obra para horários alternativos.

\subsubsection{Projetos Eficientes de Edificações e Arquitetura Bioclimática}

Um projeto de arquitetura energeticamente sustentável faz uso de seus princípios e estratégias na minimização do consumo energético de edifícios e estabelecimentos. Neste caso, o aproveitamento da luz natural, tanto no projeto de expansão, pode ocorrer através da abertura de fendas e janelas laterais e superiores, atentando, porém, para que o calor excessivo não invada e degrade o ambiente [47].

A iluminação no setor industrial possui baixíssima representatividade no consumo de eletricidade, variando entre 2 e $7 \%$ dentre os usos finais que não participam de processos de manufatura ou transformação de produtos. A eficientização da iluminação, portanto, exerce um pequeno papel nos esforços conjuntos de conservação energética do setor industrial. A escolha do recurso de projetos de bioclimática e eficientização de edifícios para integrar o estudo de caso, deve-se, entretanto, ao seu caráter diferenciado, de perspectivas interessantes de implantação em um horizonte de médio a longo prazo.

Conforme visto no item 7.3.4, a iluminação participa em 5\% do consumo de eletricidade industrial, ou 10,1 GWh. A redução de luz natural em horários comerciais em 20\% (entre 6 e 18hs, supondo uma concentração de $75 \%$ do consumo elétrico diário neste período), gera um pottencial teórico de $\mathbf{1 , 5 1}$ GWh. Considerando uma redução de apenas $10 \%$ do consumo de eletricidade por 
iluminação com a utilização de luz natural, aplicada a 25\% das indústrias, temos um potencial realizável de 252,5 MWh.

Dada a abrangência enorme de possibilidades de projetos de iluminação natural de instalações ou edificações e a necessidade de análises extensivas de especialistas para cada condição de projeto, considera-se, para este recurso, o custo de energia economizada como indeterminado. Deve-se ressalta, porém, que já existem no mercado softwares capazes de estimar o custo de tais empreendimentos em função da energia economizada [47].

\subsubsection{Armazenamento de Energia}

Para o setor industrial, ainda que o uso do condicionamento ambiental tenha baixa expressividade no consumo total de eletricidade, o armazenamento de energia foi incluído neste estudo de caso por tratar-se de uma modalidade diferenciada de deslocamento de demanda para horários alternativos, repercutindo em uma redução em gastos de eletricidade.

O tipo de armazenamento de energia considerado é o acúmulo de frio, com a produção de gelo fora do horário de ponta e seu armazenamento em termoacumuladores, para a refrigeração do ambiente por ar condicionado durante todo o período comercial. Tal ação visa, portanto a redução do consumo elétrico na ponta, ou seja, o deslocamento de picos e o preenchimento de vales da curva de carga. Assim, é uma medida de Gerenciamento pelo Lado da Demanda, mas não visa a economia de energia e sim um ganho econômico a partir do uso do equipamento refrigerador em horários onde a tarifa apresenta valores mais baixos. Desta forma, o potencial de redução de energia e conseqüentemente o custo de energia economizada não se aplicam a este caso. 


\subsubsection{Seleção de Combustíveis}

A substituição do Diesel, combustível amplamente usado por veículos de médio e grande porte no transporte interno do setor industrial, por tecnologias ambientalmente mais favoráveis pretende gerar impactos positivos de ordem global. Para este estudo de caso foi selecionada a substituição de diesel por gás natural, em função da viabilidade técnica e econômica (relacionada a custos e disponibilidade) vinculadas ao Gás Natural.

No entanto, no caso de seleção de energéticos, o consumo de combustível e conseqüentemente de energia não são os objetivos principais, apontados na Avaliação de Custos Completos como de ordem ambiental (como ganhos em termos de diminuição da poluição atmosférica a partir da utilização do Gás Natural, menos poluentes que o Diesel). Estes impactos não são, porém, quantificados neste estudo de caso. Sendo assim, o potencial de redução energética advindo da substituição de combustíveis não se aplicará neste caso.

De forma análoga, a energia consumida permanece inalterada com a substituição do combustível, ainda que o volume de combustível necessário para gerá-la, assim como seu preço associado, possam ser reduzidos. Portanto, o cálculo do custo de energia economizada não é aplicável a este caso.

\subsubsection{Eficientização de Sistemas de Combustão}

Sistemas de combustão, mais especificamente caldeiras para a geração de vapor consomem cerca de um terço da energia industrial no segmento de alimentos. Esta porção corresponde, na Região de Araçatuba, a 24.364 tep ou 336 GWh. Considerando um potencial de conservação de 25\% [41], seriam economizados 
6091 tep ou 84 GWh. Estimando uma penetração de medidas de eficientização de caldeiras como aparatos de conservação, substituição de caldeiras ou retrofitting, redução de perdas e práticas corretas de operação e manutenção em um terço das indústrias locais e uma redução de consumo energético de 15\%, o potencial realizável estaria estimado em 365,5 tep ou 16,8 GWh. O custo de investimento do retrofitting de caldeiras é estimado em US\$2000/MW [42]. Assim, para um consumo de 336 GWh em uma média anual de 2000 horas de operação, o custo total do investimento seria de US\$ 336.000. Para uma economia de 84 GWh, o custo da energia economizada, é portanto, de US\$ 4/MWh.

\subsubsection{Potenciais Energéticos e Custo de Energia Economizada}

Na tabela 7.3.10 abaixo são exibidos os resultados dos potenciais teóricos e realizáveis dos recursos selecionados, bem como o custo da energia economizada na implantação de tais empreendimentos. Convencionou-se, neste estudo de caso, que os potenciais teóricos de redução de consumo seriam plenamente possíveis apenas no instante final de análise, para o cenário de desenvolvimento sustentável, tanto do ponto de vista técnico-econômico quanto sócio-político.

Há na tabela alguns casos de não aplicabilidade, referentes a medidas voltadas estritamente ao deslocamento da demanda ou à substituição de combustíveis, sem que isto implique em redução de consumo energético. É importante ressaltar que ainda que a mensuração da redução de demanda das alternativas energéticas estudadas neste estudo de caso não tenha sido identificada, esta medida é de extrema importância, ainda que indiretamente, no planejamento energético, ao contribuir para a postergação da ampliação da capacidade do sistema energético. Neste mesmo raciocínio, recursos energéticos que não registrem 
reduções de conservação energética não devem, de modo algum, ter sua importância diminuída na análise.

Tabela 7.4.10: Potenciais Energéticos e Custo da Energia Economizada

\begin{tabular}{|l|c|c|c|}
\hline $\begin{array}{l}\text { Recursos do Lado da } \\
\text { Demanda }\end{array}$ & $\begin{array}{c}\text { Potencial } \\
\text { Teórico } \\
\text { (GWh/ano) }\end{array}$ & $\begin{array}{c}\text { Potencial } \\
\text { Realizável } \\
\text { (GWh/ano) }\end{array}$ & $\begin{array}{c}\text { Custo da En. } \\
\text { Economizada } \\
\text { (US\$/MWh) }\end{array}$ \\
\hline Controladores de Demanda & - & - & - \\
\hline Iluminação & 4,04 & 0,505 & 20,00 \\
\hline $\begin{array}{l}\text { Uso Eficiente de Motores } \\
\text { Elétricos }\end{array}$ & 25,2 & 3,02 & 25,00 \\
\hline $\begin{array}{l}\text { Refrigeração Eficiente } \\
\text { Substituição de Combustíveis } \\
\text { (Veicular: Diesel por GNV) }\end{array}$ & 24,2 & 1,21 & 5,00 \\
\hline $\begin{array}{l}\text { Eficientização de Sistemas de } \\
\text { Combustão }\end{array}$ & 84 & 16,8 & - \\
\hline $\begin{array}{l}\text { Tarifas Alternativas } \\
\text { Projetos Eficientes de }\end{array}$ & 1,51 & 0,25 & - \\
\hline $\begin{array}{l}\text { Edificações } \\
\text { (Termazenamento de Energia }\end{array}$ & - & - & - \\
\hline
\end{tabular}




\subsection{Cenários Energéticos}

A análise de projeções e cenários possibilita a compreensão dos diferentes fatores capazes de alterar o comportamento energético futuro. Entre eles temos o desenvolvimento tecnológico, o crescimento econômico, políticas governamentais e uma ampla possibilidade de respostas de consumidores. A soma de todos estes fatores constitui um importante vetor capaz de modificar o perfil e a intensidade do uso de energia.

Desta forma, a parte final do estudo de caso pretende construir diferentes cenários para a região de Araçatuba, com perspectivas de diferentes taxas de crescimento de consumo e inserção de tecnologias eficientes.

A partir de um cenário referencial que não considera a implantação de medidas de gerenciamento de demanda e eficiência energética, são construídos dois cenários adicionais. O primeiro deles, de Consumo Sustentável adota premissas máximas de adoção de recursos de GLD num horizonte de trinta anos. O segundo cenário, mais conservador, contempla uma proporção equilibrada entre recursos eficientes e não eficientes, ao final dos trinta anos de análise.

Para a construção destes cenários foi utilizado o LEAP (Long-range energy alternatives planning system). O LEAP é uma ferramenta de modelagem energética baseada em cenários, desenvolvida pela Stockholm Enviroment Institute, nos Estados Unidos. Conta com o apoio de diversas universidades ao redor do mundo, de onde busca informações para a criação de seu próprio banco de dados, que possibilita a pesquisa de diversas formas de geração e usos da energia elétrica no mundo, além da criação e armazenamento de dados próprios ou mistos para utilização em simulações. 
$\mathrm{Na}$ elaboração dos cenários podem ser considerados diferentes fatores energéticos como utilização, conversão e produção de energia em uma região específica, além de parâmetros como crescimento populacional, desenvolvimento econômico, preços, entre outros. É possível ainda simular projeções a longo prazo da demanda de energia, permitindo estimar o crescimento de uma região e, desta maneira, fornecer dados mais precisos para o planejamento da expansão da oferta energética. Para maiores detalhes acerca do LEAP, vide a referência [44].

Para este estudo foram elaboradas duas diferentes simulações de cenários. A primeira delas considera apenas a energia elétrica e a segunda contempla a energia total utilizada no setor industrial.

Na elaboração dos cenários deste estudo de caso foram considerados como usos finais de energia elétrica a força motriz (com uma participação de $50 \%$ do consumo nas indústrias), a refrigeração (com 30\% do consumo de eletricidade), a iluminação (5\%) e o condicionamento ambiental (3\%). Aos demais usos finais coube o restante, de 12\%. Para o cenário de energia total, foram considerados como usos finais o calor utilizado em processos de combustão (65\%), refrigeração de processos (15\%), força motriz (10\%), transporte interno de veículos (2\%), iluminação e condicionamento ambiental (1\% cada).

\subsubsection{Cenário Referencial}

Neste cenário referencial, de cunho conservador, foi considerado um crescimento anual de 1,5\% no consumo energético e uma baixa penetração de equipamentos eficientes no setor industrial, de apenas $10 \%$ ao final de 30 anos de horizonte, enquanto $90 \%$ do mercado continuaria com equipamentos padrão.

Estipulou-se uma eficiência média de equipamentos padrão de 50\%, contra $60 \%$ para equipamentos eficientes, no caso de motores elétricos e sistemas de 
combustão, e de $50 \%$ contra $70 \%$ no caso de refrigeradores, condicionadores e lâmpadas. Neste cenário os índices de eficiência não sofreriam alteração durante o horizonte de análise, ou seja, depois de 30 anos, equipamentos padrão continuariam com uma eficiência de $50 \%$ contra 60 ou $70 \%$ de eficiência de equipamentos eficientes.

Os resultados deste cenário, num horizonte de 30 anos, podem ser visto nos gráficos (Figura 7.5.1.a e 7.5.1.b) a seguir.

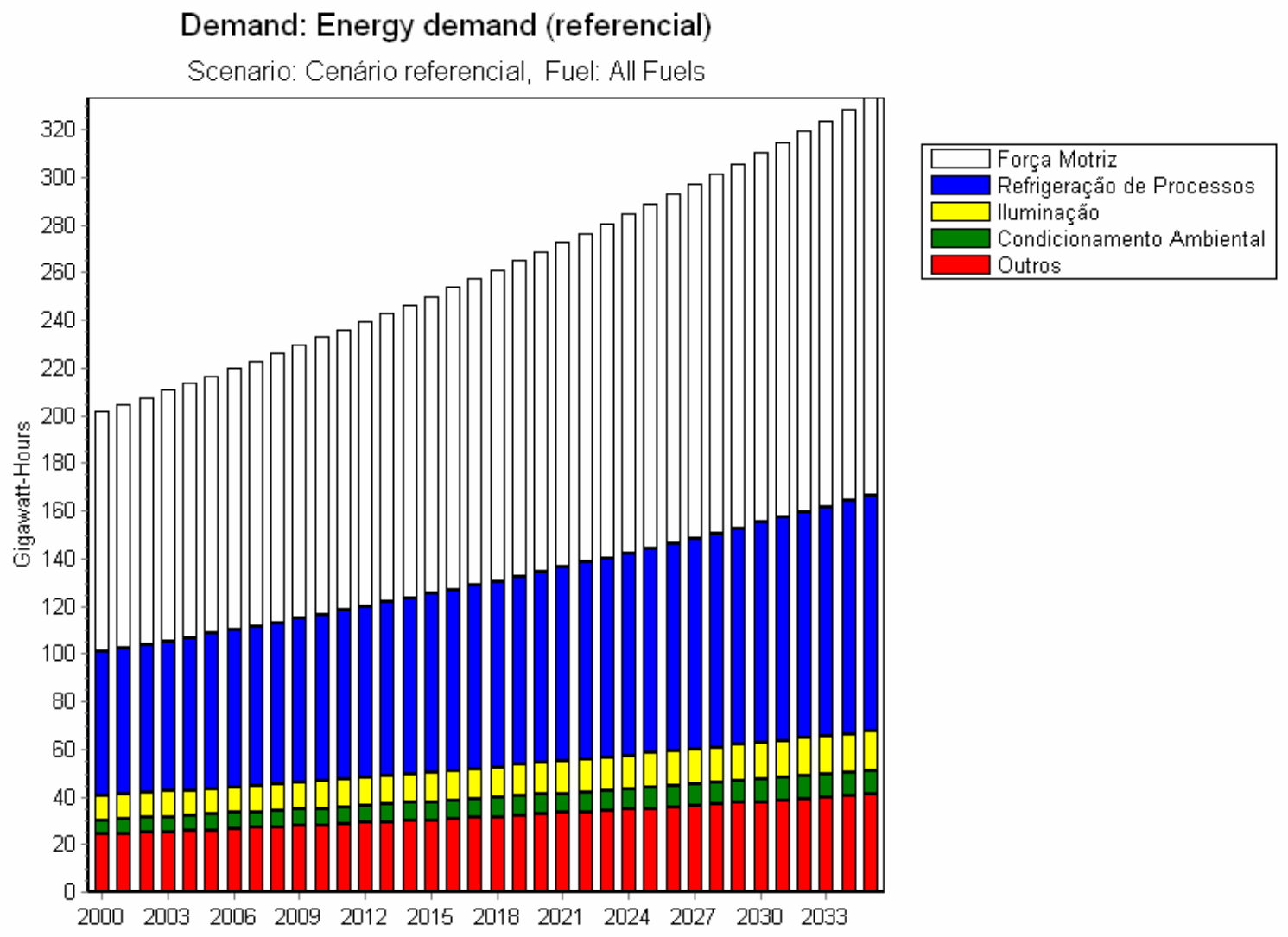

Figura 7.5.1.a: Cenário Referencial -Eletricidade (2000-2035) 


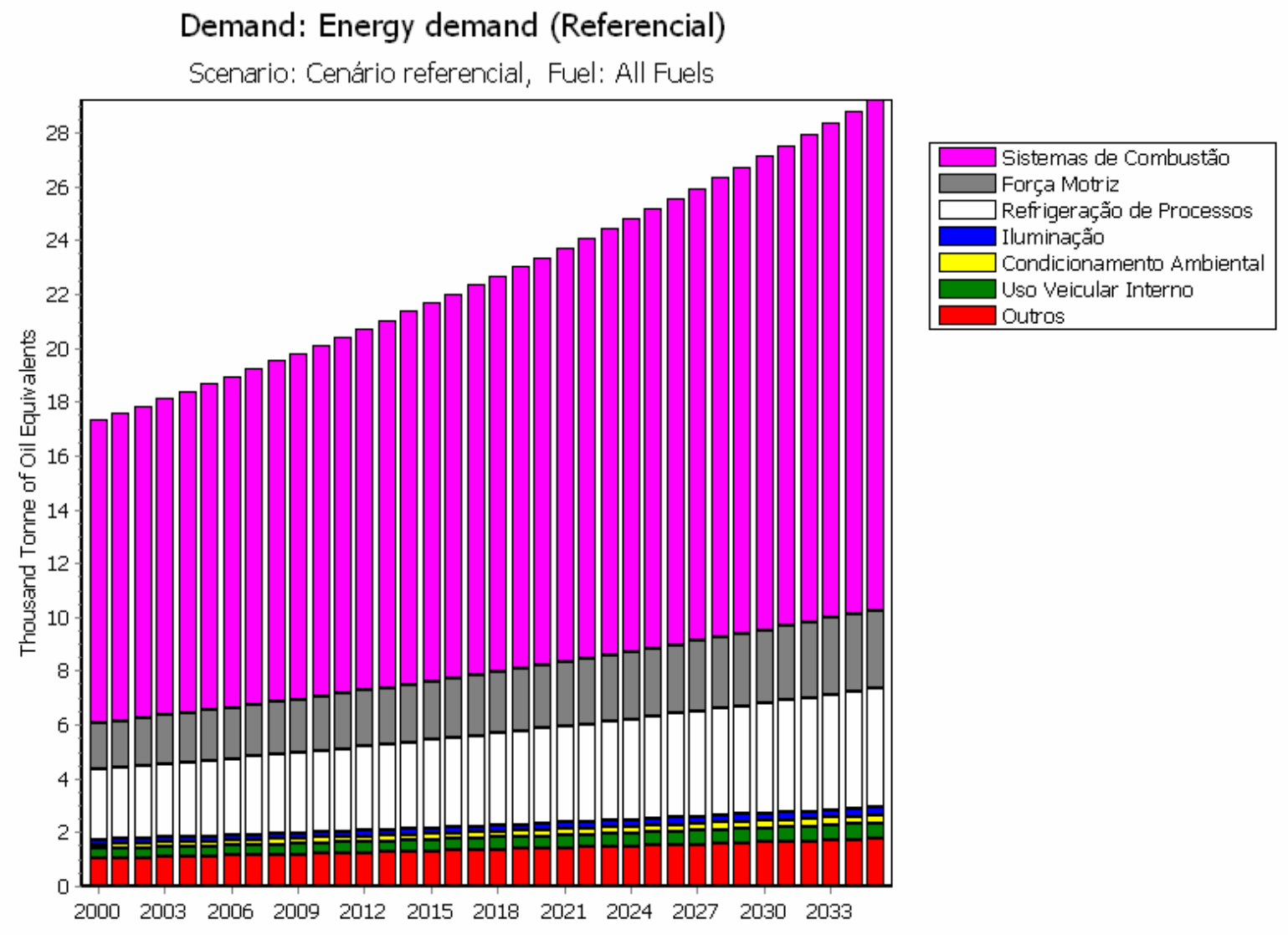

Figura 7.5.1.b: Cenário Referencial -Energia (2000-2035)

\subsubsection{Cenário de Consumo Realizável}

O cenário de consumo realizável, de parâmetros intermediários aos cenários de referência e sustentável, considerou um crescimento praticável ou real de recursos energéticos eficientes ao longo do horizonte de análise. O crescimento anual do consumo energético ainda é de $1,5 \%$, mas a penetração de equipamentos eficientes no setor industrial é estimada a $50 \%$ ao final de 30 anos de horizonte, dividindo o mercado com equipamentos padrão.

Novamente estipulou-se uma eficiência média de equipamentos padrão de $50 \%$, contra $60 \%$ para equipamentos eficientes, no caso de motores elétricos e sistemas de combustão, e de $50 \%$ contra $70 \%$ no caso de refrigeradores, condicionadores e lâmpadas. Neste cenário, os índices de crescimento de eficiência 
de equipamentos padrão são estimados em $5 \%$ durante o período de análise, e os índices de equipamentos eficientes são estimados em 10\% para o mesmo período.

Os resultados dos cenários realizáveis estão nas figura 7.5.2.a e b a seguir.

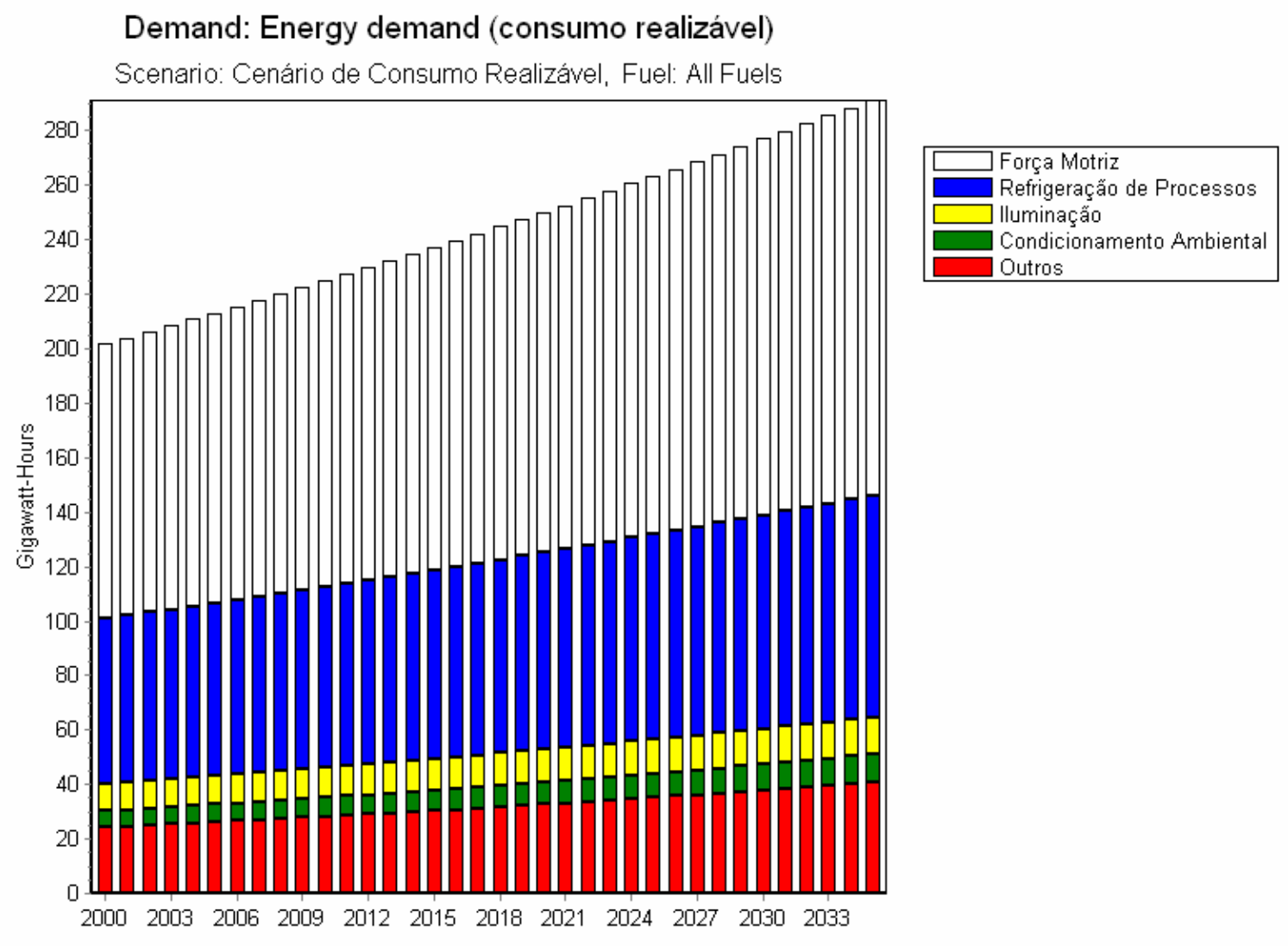

Figura 7.5.2.a: Cenário de Consumo Realizável - Eletricidade (2000-2035) 
Demand: Energy demand (Realizável)

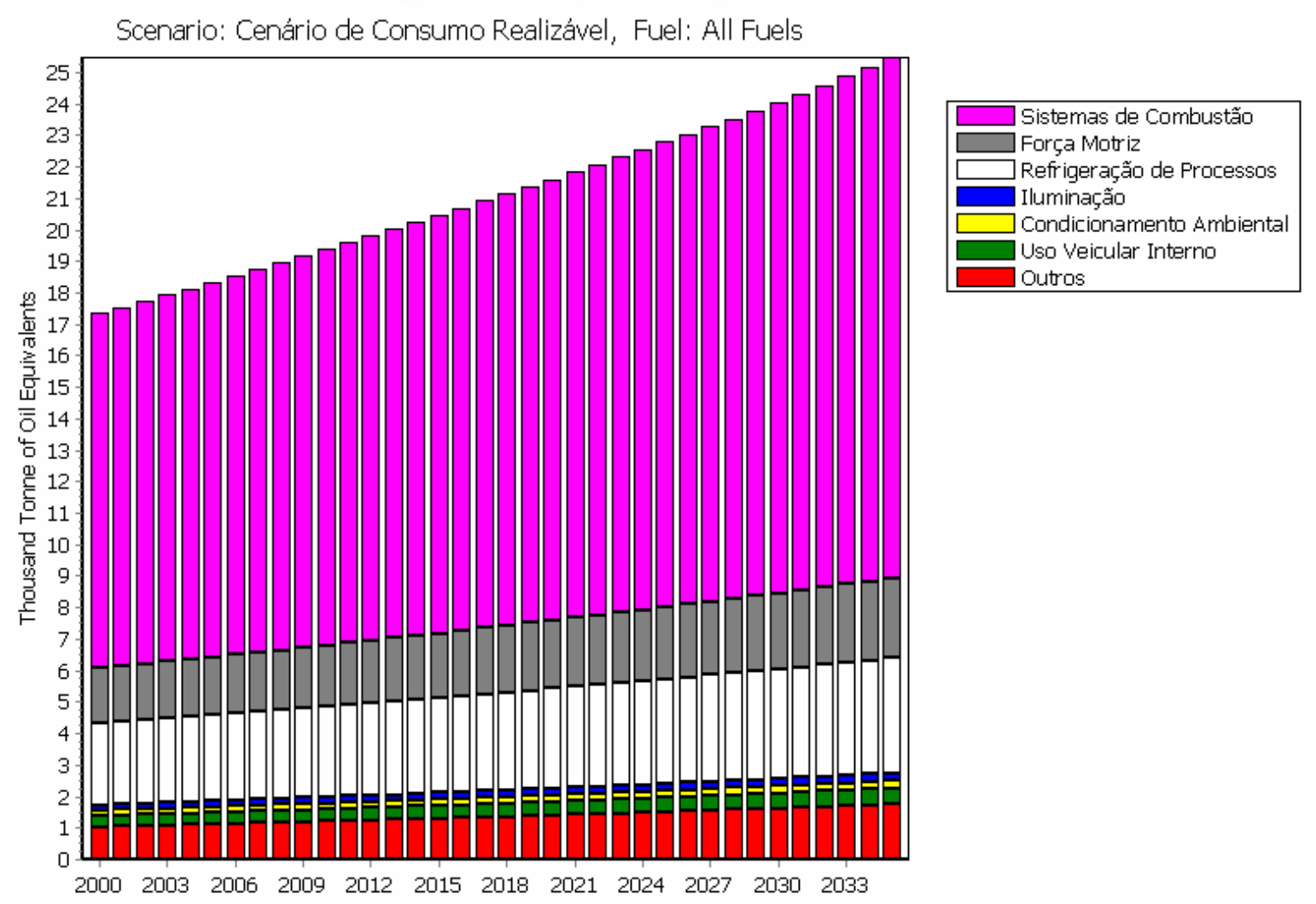

Figura 7.5.2.b: Cenário de Consumo Realizável - Energia (2000-2035)

\subsubsection{Cenário Sustentável ou Eficiência Maximizada}

O terceiro cenário, sustentável ou de eficiência maximizada, vislumbra as melhores condições quanto ao consumo racional de energia. É estabelecido um crescimento de consumo de apenas $1 \%$ ao ano, e estima-se que, ao final do período de projeção dos cenários, $100 \%$ de equipamentos utilizados nos diversos usos finais sejam eficientes.

Novamente estipulou-se uma eficiência média de equipamentos padrão de $50 \%$, contra $60 \%$ para equipamentos eficientes, no caso de motores elétricos e sistemas de combustão, e de $50 \%$ contra $70 \%$ no caso de refrigeradores, condicionadores e lâmpadas. Desta vez, porém, os índices de eficiência de equipamentos padrão são estimados a uma taxa de crescimento de $10 \%$ e os eficientes de $20 \%$, durante os 30 anos de análise. 
Nas figuras 7.5.3.a e b a seguir, pode-se ver o comportamento do consumo energético na região, para um horizonte de 30 anos a partir do ano atual de referência.

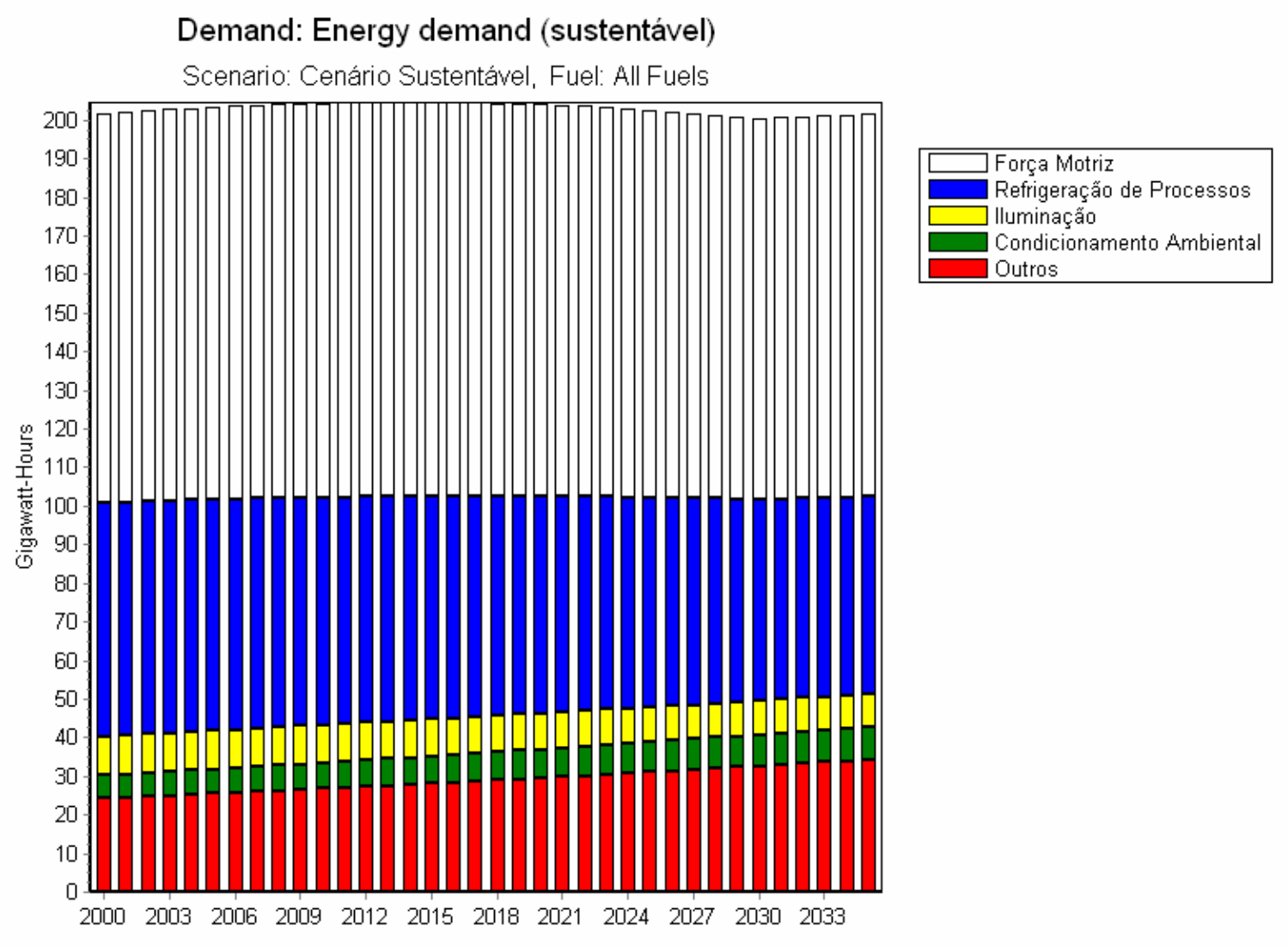

Figura 7.5.3.a: Cenário de Eficiência Maximizada - Eletricidade (2000-2035) 


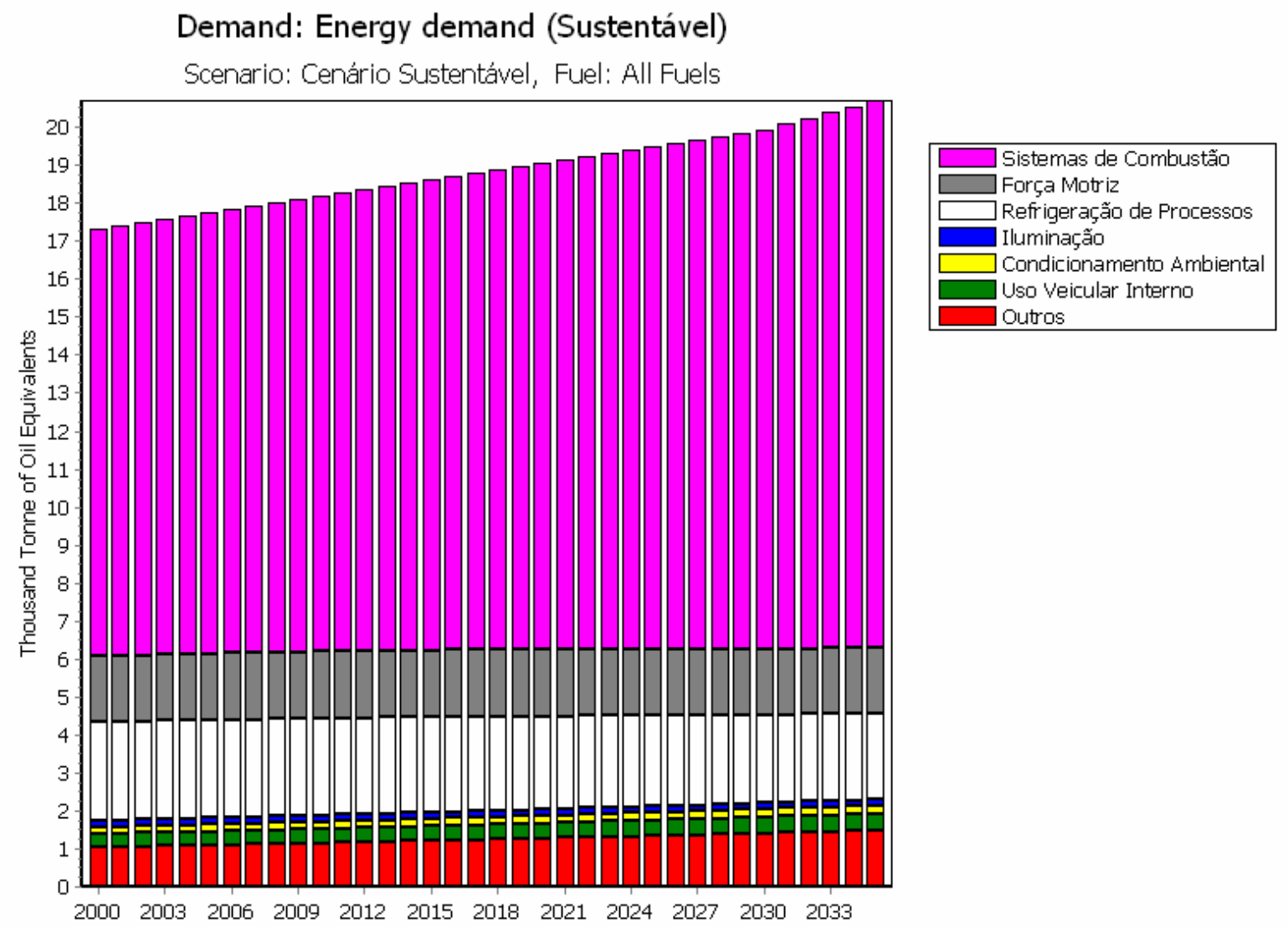

Figura 7.5.3.b: Cenário de Eficiência Maximizada - Energia (2000-2035)

\subsection{Considerações sobre os resultados do Estudo de Caso}

O Estudo de Caso na região de Araçatuba prestou-se a testar na prática, baseado em dados mesclando valores reais e estipulados, a validade do Modelo de Caracterização de RELD. Há algumas observações pertinentes quanto à condução de cada etapa do Modelo, como o levantamento de usos finais, a seleção de medidas de GLD, o direcionamento da análise para um determinado setor de consumo, o cálculo dos diferentes potenciais e a elaboração de cenários.

Em relação à Avaliação de Custos Completos, a metodologia de pontuações seguida foi um acréscimo gradual na avaliação de diversos recursos, representada em quatro planilhas (2005, 2015, 2025 e 2035) ao longo dos anos. As dimensões que sofreram diferenças mais sensíveis em termos de pontuação foram a social e a 
política, uma vez que foram vislumbradas mudanças positivas quanto à aceitação e compreensão de recursos do lado da demanda, tanto por parte da sociedade, quanto do governo e dos envolvidos e interessados como um todo. Conforme percebido, há uma série de recursos que não participaram da avaliação por diferentes critérios, como não-aplicabilidade. Por outro lado, recursos com baixo potencial, mas de caráter inovador ou expressivo em um horizonte futuro, participaram da avaliação. De forma análoga, alguns atributos não se aplicaram a determinados recursos, recebendo uma pontuação neutra $x$, equivalente à media do referido recurso naquela dimensão, a fim de que não fosse alterada sua pontuação.

O cálculo dos potenciais e dos custos de energia economizada não partiram necessariamente de uma medida específica de eficientização para cada uso final e sim de um índice de eficiência estimado a partir de um mix de diferentes casos bem sucedidos de eficientização de sistemas ou seleção de combustíveis.

No caso dos cenários de consumo de energia, não foram considerados especificamente fatias de energia economizada a partir da adoção de um dado recurso eficiente. Optou-se por considerar uma penetração gradual de tais recursos no mercado, em maior ou menor grau de acordo com o cenário elaborado. Quanto às eficiências de recursos padrão e eficientes, optou-se por adotar um crescimento diferenciado para ambas, a fim de reproduzir um ambiente real no qual recursos considerados eficientes no momento presente tornam-se recursos de eficiência padrão no futuro e níveis cada vez mais elevados de eficiência são obtidos ao longo do tempo. 


\section{Conclusões}

Esta dissertação propôs um modelo de caracterização de recursos energéticos do lado da demanda. Esta modelagem consistiu em levantar todas as opções presentes e futuras de medidas de eficientização energética e gerenciamento da demanda, classificar as opções selecionadas dentro de quatro dimensões de análise (técnico-econômica, ambiental, social e política) e formular o cálculo de seu potencial energético em âmbito máximo, realizável e adequado ao mercado do instante de análise.

Este modelo de caracterização e análise dos RELD é de importância crucial ao processo de planejamento energético, uma vez que constitui a etapa inicial de tratamento e seleção de recursos energéticos e, em congruência com a modelagem dos recursos energéticos de oferta, é capaz de apontar opções energéticas adequadas à integração de recursos e conseqüentemente à sua inserção temporal em um plano preferencial.

Por meio do Estudo de Caso foi possível a comprovação de que a modelagem é capaz de caracterizar as opções mais adequadas de recursos energéticos do lado da demanda, possibilitando sua análise espacial e temporal e sua inter-relação com os demais recursos, de modo a compor carteiras de recursos em uma etapa posterior de PIR.

Desta forma, conclui-se que a modelagem e a análise de RELD contribui para o PIR, moldando recursos brutos representados essencialmente por tecnologias de uso final com potenciais de aumento de eficiência energética, de modo a inserí-los em etapas subseqüentes do planejamento. Deve-se ressaltar novamente que a modelagem e a análise de RELD constitui, juntamente com o modelo de caracterização dos RELO, as etapas iniciais do PIR. Desta forma, o processamento 
correto do conjunto de recursos energéticos, por ambos os modelos, contribuirá de forma decisiva às etapas subseqüentes de PIR, de integração de recursos, formação de carteiras e execução do plano preferencial.

Ainda que o modelo caracterize, analise e mensure recursos energéticos, é importante lembrar que estes prosseguirão em constante processo de refinamento em etapas posteriores do PIR, em novas seleções e reavaliações de seus potenciais e sua aplicabilidade. Algumas destas etapas já foram abordadas em dissertações de mestrado ou teses de doutorado em nosso grupo de pesquisa, como a Integração de Recursos Energéticos, a Análise de Recursos Energéticos por meio de ferramentas como a Avaliação de Custos Completos ou a Análise de Ciclo de Vida, e o processo de PIR como um todo. Outras estão sendo correntemente desenvolvidas como a Elaboração de Carteiras, o Estudo de Processos Hierárquicos de Análise e a Inserção dos atores Envolvidos e Interessados no processo de viabilização de empreendimentos energéticos. 


\section{ANEXO: Tabelas da Avaliação de Custos Completos}

As Tabelas A1, A2, A3 e A4 a seguir definem a pontuação referente a cada classificação das escalas de avaliação e os respectivos pesos concedidos a cada atributo. A conceituação da atribuição de pesos e valores é formalizada e trabalhada em detalhes na Dissertação de Mestrado de Boarati [70].

Tabela A 1: Dimensão Técnico-Econômica - Correspondência de Avaliações

\begin{tabular}{|c|c|c|c|c|c|c|}
\hline & 10 & 7,5 & 5 & 2,5 & 0 & Peso \\
\hline $\begin{array}{c}\text { Custo do } \\
\text { Empreendimento } \\
\text { (US\$/MW) }\end{array}$ & Custo $<100$ & $\begin{array}{c}100<\text { custo }<= \\
200\end{array}$ & $300<$ custo $<=400$ & $\begin{array}{c}400<\text { custo }< \\
=500\end{array}$ & Custo $>500$ & 4 \\
\hline $\begin{array}{c}\text { Potencial Relativo } \\
\text { de GLD }\end{array}$ & Alto & & Médio & & Baixo & 1 \\
\hline $\begin{array}{l}\text { Custo da Energia } \\
\text { Economizada } \\
\text { (US\$/MWh) }\end{array}$ & Custo $<=5$ & $\begin{array}{c}5<\text { custo }< \\
10\end{array}$ & $10<$ custo $<20$ & $\begin{array}{c}20<\text { custo }< \\
30\end{array}$ & Custo $>30$ & 4 \\
\hline $\begin{array}{l}\text { Incentivos tarifários } \\
\text { à adoção de } \\
\text { programas de GLD }\end{array}$ & $\begin{array}{l}\text { Incentivos } \\
\text { substanciais }\end{array}$ & & Incentivos limitados & & $\begin{array}{l}\text { Ausência de } \\
\text { incentivos }\end{array}$ & 3 \\
\hline $\begin{array}{c}\text { Tempo de } \\
\text { Implantação }\end{array}$ & $\begin{array}{c}\text { Tempo }<=3 \\
\text { meses }\end{array}$ & & $\begin{array}{c}3 \text { meses }<\text { tempo }<=1 \\
\text { anos }\end{array}$ & & $\begin{array}{c}\text { Tempo }>1 \\
\text { anos }\end{array}$ & 2 \\
\hline $\begin{array}{l}\text { Tempo de Retorno } \\
\text { do Investimento }\end{array}$ & $\begin{array}{c}\text { Tempo }<=1 \\
\text { ano }\end{array}$ & & $\begin{array}{c}1 \text { ano }<=\text { tempo }<=3 \\
\text { anos }\end{array}$ & & $\begin{array}{c}\text { Tempo }>3 \\
\text { anos }\end{array}$ & 4 \\
\hline $\begin{array}{c}\text { Domínio } \\
\text { Tecnológico } \\
\end{array}$ & Nacional & & $\begin{array}{c}\text { Parcialmente } \\
\text { nacional }\end{array}$ & & Importado & 3 \\
\hline $\begin{array}{c}\text { Grau de } \\
\text { Necessidade de } \\
\text { Monitoração e } \\
\text { Manutenção }\end{array}$ & Baixo & & médio & & Alto & 3 \\
\hline $\begin{array}{c}\text { Qualidade da } \\
\text { Energia gerenciada }\end{array}$ & $\begin{array}{l}\text { Alterações } \\
\text { positivas }\end{array}$ & & Sem alterações & & $\begin{array}{l}\text { Alterações } \\
\text { negativas }\end{array}$ & 2 \\
\hline $\begin{array}{l}\text { Estrutura de } \\
\text { Marketing e } \\
\text { Propaganda } \\
\text { Estratégica }\end{array}$ & $\begin{array}{l}\text { Ampla } \\
\text { estrutura }\end{array}$ & & Marketing limitado & & $\begin{array}{l}\text { Ausência de } \\
\text { propaganda }\end{array}$ & 0 \\
\hline
\end{tabular}

Tabela A 2: Dimensão Ambiental

\begin{tabular}{|c|c|c|c|c|c|c|}
\hline & $\mathbf{1 0}$ & $\mathbf{7 , 5}$ & $\mathbf{5}$ & $\mathbf{2 , 5}$ & $\mathbf{0}$ & Peso \\
\hline Poluição Atmosférica & $\begin{array}{c}\text { Poluição } \\
\text { atmosférica } \\
\text { evitada }\end{array}$ & & $\begin{array}{c}\text { Não afeta a } \\
\text { qualidade do ar }\end{array}$ & & $\begin{array}{c}\text { Poluição } \\
\text { atmosférica } \\
\text { considerável }\end{array}$ & $\begin{array}{c}\text { Poluição } \\
\text { considerável }\end{array}$ \\
\hline Poluição das Águas & $\begin{array}{c}\text { Poluição } \\
\text { evitada }\end{array}$ & & Poluição nula & & $\mathbf{1}$ \\
\hline Poluição do Solo & $\begin{array}{c}\text { Poluição } \\
\text { evitada }\end{array}$ & & Poluição nula & & $\begin{array}{c}\text { Poluição } \\
\text { considerável }\end{array}$ \\
\hline
\end{tabular}


Tabela A 3: Dimensão Social

\begin{tabular}{|c|c|c|c|c|c|c|}
\hline & 10 & 7,5 & 5 & 2,5 & 0 & Peso \\
\hline $\begin{array}{c}\text { Efeitos do } \\
\text { desequilíbrio } \\
\text { ambiental no meio } \\
\text { social }\end{array}$ & Não polui & & $\begin{array}{l}\text { Desconforto } \\
\text { moderado }\end{array}$ & & $\begin{array}{c}\text { Ruídos nocivos } \\
\text { à população } \\
\text { vizinha }\end{array}$ & 2 \\
\hline $\begin{array}{c}\text { Influência no Mercado } \\
\text { de Trabalho - Geração } \\
\text { de Empregos }\end{array}$ & $\begin{array}{c}\text { Grande } \\
\text { Quantidade e } \\
\text { Qualidade de } \\
\text { empregos }\end{array}$ & & $\begin{array}{l}\text { Alta Quanti e } \\
\text { Baixa Quali ou } \\
\text { vice-versa }\end{array}$ & & $\begin{array}{c}\text { Baixa } \\
\text { Quantidade } \\
\text { e/ou Qualidade } \\
\text { de empregos }\end{array}$ & 4 \\
\hline $\begin{array}{c}\text { Considerações } \\
\text { funcionais e estéticas } \\
\text { de Recursos }\end{array}$ & $\begin{array}{l}\text { Não interferem } \\
\text { na adoção e } \\
\text { utilização de } \\
\text { equipamentos }\end{array}$ & & $\begin{array}{c}\text { Influência } \\
\text { moderada na } \\
\text { utilização de } \\
\text { equipamentos }\end{array}$ & & $\begin{array}{c}\text { Obstáculo à } \\
\text { disseminação } \\
\text { de tecnologias }\end{array}$ & 2 \\
\hline
\end{tabular}

Tabela A 4: Dimensão Política

\begin{tabular}{|c|c|c|c|c|c|c|}
\hline & 10 & 7,5 & 5 & 2,5 & 0 & Peso \\
\hline $\begin{array}{c}\text { Aceitação/Oposição } \\
\text { a Recursos do Lado } \\
\text { da Demanda }\end{array}$ & $\begin{array}{l}\text { Aceitação } \\
\text { considerável }\end{array}$ & & $\begin{array}{l}\text { Aceitação e } \\
\text { oposição } \\
\text { equilibradas }\end{array}$ & & $\begin{array}{l}\text { Oposição } \\
\text { severa }\end{array}$ & 5 \\
\hline $\begin{array}{c}\text { Apoio } \\
\text { Governamental }\end{array}$ & $\begin{array}{c}\text { Governo é } \\
\text { ativamente } \\
\text { favorável à adoção } \\
\text { do recurso }\end{array}$ & $\begin{array}{l}\text { Governo é } \\
\text { passivamente } \\
\text { favorável à } \\
\text { adoção do } \\
\text { recurso }\end{array}$ & $\begin{array}{l}\text { Governo é } \\
\text { indiferente }\end{array}$ & $\begin{array}{l}\text { Governo é } \\
\text { passivamente } \\
\text { oposto à } \\
\text { adoção do } \\
\text { recurso }\end{array}$ & $\begin{array}{l}\text { Governo é } \\
\text { ativamente } \\
\text { oposto à } \\
\text { adoção do } \\
\text { recurso }\end{array}$ & 1 \\
\hline $\begin{array}{l}\text { Conjunção e } \\
\text { Encontro de } \\
\text { Interesses }\end{array}$ & $\begin{array}{l}\text { Elevado: usuários } \\
\text { compreendem o } \\
\text { recurso e são } \\
\text { capazes de usufruí- } \\
\text { lo }\end{array}$ & & $\begin{array}{l}\text { Moderado: } \\
\text { usuários são } \\
\text { capazes de } \\
\text { usufruí-lo de } \\
\text { forma restrita }\end{array}$ & & $\begin{array}{c}\text { Baixo: } \\
\text { usuários não } \\
\text { compreendem } \\
\text { e são } \\
\text { reticentes } \\
\text { quanto ao } \\
\text { recurso } \\
\end{array}$ & 3 \\
\hline $\begin{array}{c}\text { Risco a Exposição } \\
\text { Cambial }\end{array}$ & $\begin{array}{l}\text { Tecnologia nacional } \\
\text { sem risco cambial } \\
\text { nos fluxos de caixa }\end{array}$ & & $\begin{array}{l}\text { Tecnologia } \\
\text { mista, com } \\
\text { risco cambial } \\
\text { parcial nos } \\
\text { fluxos de caixa }\end{array}$ & & $\begin{array}{c}\text { Tecnologia } \\
\text { importada com } \\
\text { grande } \\
\text { influência do } \\
\text { câmbio nos } \\
\text { fluxos de caixa }\end{array}$ & 3 \\
\hline $\begin{array}{c}\text { Potencial } \\
\text { conscientização do } \\
\text { uso racional e } \\
\text { participação no } \\
\text { gerenciamento da } \\
\text { energia }\end{array}$ & $\begin{array}{l}\text { Alto potencial de } \\
\text { incentivo ao uso } \\
\text { racional }\end{array}$ & & $\begin{array}{c}\text { Potencial } \\
\text { moderado de } \\
\text { participação e } \\
\text { conscientização }\end{array}$ & & $\begin{array}{c}\text { Potencial nulo } \\
\text { de } \\
\text { participação e } \\
\text { uso racional }\end{array}$ & 4 \\
\hline
\end{tabular}


As Tabelas A5, A6, A7 e A8 a seguir exibem as pontuações recebidas por cada recurso energético em relação a cada atributo, nas quatro dimensões de análise. O primeiro instante de avaliação é o ano de 2005. A conceituação da atribuição de pontuações para cada recurso energético é formalizada e trabalhada em detalhes na Dissertação de Mestrado de Boarati [70].

Tabela A 5: Dimensão Técnico-Econômica - Pontuações 2005

\begin{tabular}{|c|c|c|c|c|c|c|c|c|c|}
\hline & $\begin{array}{l}\text { Controla- } \\
\text { dor de } \\
\text { Demanda }\end{array}$ & $\begin{array}{l}\text { Ilumi- } \\
\text { nação }\end{array}$ & $\begin{array}{l}\text { Uso } \\
\text { Efici- } \\
\text { ente de } \\
\text { Motores } \\
\text { Elétricos }\end{array}$ & $\begin{array}{l}\text { Refrige- } \\
\text { ração } \\
\text { Eficiente }\end{array}$ & $\begin{array}{l}\text { Substitui- } \\
\text { ção } \\
\text { Veicular - } \\
\text { Diesel } \\
\text { por GNV }\end{array}$ & \begin{tabular}{|c|} 
Eficientiza- \\
ção de \\
Sistemas \\
de \\
Combustão
\end{tabular} & $\begin{array}{l}\text { Tarifas } \\
\text { Alter- } \\
\text { nativas }\end{array}$ & $\begin{array}{l}\text { Edifica- } \\
\text { ções } \\
\text { Efici- } \\
\text { entes }\end{array}$ & $\begin{array}{c}\text { Armaze- } \\
\text { namento } \\
\text { de } \\
\text { Energia }\end{array}$ \\
\hline $\begin{array}{c}\text { Custo do } \\
\text { Empreendimento } \\
\text { (US\$/MW) }\end{array}$ & 5 & 0 & 5 & 7,5 & 5 & 0 & 10 & $x$ & 5 \\
\hline $\begin{array}{c}\text { Potencial } \\
\text { Relativo de GLD }\end{array}$ & 10 & 7,5 & 10 & 5 & 10 & 10 & 0 & 5 & 10 \\
\hline $\begin{array}{l}\text { Custo da } \\
\text { Energia } \\
\text { Economizada } \\
\text { (US\$/MWh) }\end{array}$ & $x$ & 2,5 & 2,5 & 7,5 & $x$ & 10 & $x$ & $x$ & $x$ \\
\hline $\begin{array}{c}\text { Incentivos } \\
\text { tarifários à } \\
\text { adoção de } \\
\text { programas de } \\
\text { GLD }\end{array}$ & 5 & 0 & 0 & 0 & $x$ & $x$ & $x$ & $x$ & 0 \\
\hline $\begin{array}{c}\text { Tempo de } \\
\text { Implantação }\end{array}$ & 10 & 10 & 5 & 5 & 10 & 5 & 10 & 5 & 5 \\
\hline $\begin{array}{c}\text { Tempo de } \\
\text { Retorno do } \\
\text { Investimento }\end{array}$ & 10 & 5 & 5 & 5 & 10 & 0 & 0 & $x$ & 5 \\
\hline $\begin{array}{c}\text { Domínio } \\
\text { Tecnológico } \\
\end{array}$ & 10 & 10 & 10 & 10 & 10 & 5 & 5 & 10 & 5 \\
\hline $\begin{array}{l}\text { Grau de } \\
\text { Necessidade de } \\
\text { Monitoração e } \\
\text { Manutenção } \\
\end{array}$ & 0 & 10 & 2,5 & 2,5 & 10 & 5 & 0 & 10 & 0 \\
\hline $\begin{array}{c}\text { Qualidade da } \\
\text { Energia } \\
\text { gerenciada }\end{array}$ & 5 & 0 & 10 & 10 & $x$ & $x$ & 5 & 5 & 5 \\
\hline $\begin{array}{l}\text { Estrutura de } \\
\text { Marketing e } \\
\text { Propaganda } \\
\text { Estratégica } \\
\end{array}$ & 0 & 5 & 5 & 5 & 5 & 5 & 0 & 0 & 0 \\
\hline Total & 145 & 127,5 & 137,5 & 162,5 & 160 & 100 & 85 & 85 & 85 \\
\hline $\begin{array}{c}\text { Total } \\
\text { Ponderado }\end{array}$ & 6,0417 & 4,5536 & 4,9107 & 5,8036 & 8,4211 & 4,3478 & 4,0476 & 6,5385 & 3,5417 \\
\hline
\end{tabular}


Tabela A 6: Dimensão Ambiental - Pontuações 2005

\begin{tabular}{|c|c|c|c|c|c|c|c|c|c|}
\hline & $\begin{array}{l}\text { Controla- } \\
\text { dor de } \\
\text { Demanda }\end{array}$ & $\begin{array}{l}\text { llumi- } \\
\text { nação }\end{array}$ & $\begin{array}{c}\text { Uso } \\
\text { Efici- } \\
\text { ente de } \\
\text { Motores } \\
\text { Elétricos }\end{array}$ & $\begin{array}{l}\text { Refrige- } \\
\text { ração } \\
\text { Eficiente }\end{array}$ & $\begin{array}{l}\text { Substitui- } \\
\text { ção } \\
\text { Veicular - } \\
\text { Diesel } \\
\text { por GNV }\end{array}$ & $\begin{array}{l}\text { Eficientiza- } \\
\text { ção de } \\
\text { Sistemas } \\
\text { de } \\
\text { Combustão }\end{array}$ & $\begin{array}{c}\text { Tarifas } \\
\text { Alter- } \\
\text { nativas }\end{array}$ & $\begin{array}{l}\text { Edifica- } \\
\text { ções } \\
\text { Efici- } \\
\text { entes }\end{array}$ & $\begin{array}{c}\text { Armaze- } \\
\text { namento } \\
\text { de } \\
\text { Energia }\end{array}$ \\
\hline $\begin{array}{c}\text { Poluição } \\
\text { Atmosférica }\end{array}$ & 5 & 2,5 & 5 & 5 & 10 & 7,5 & 5 & 5 & 5 \\
\hline $\begin{array}{c}\text { Poluição das } \\
\text { Águas }\end{array}$ & 5 & 0 & 5 & 5 & 5 & 7,5 & 5 & 5 & 5 \\
\hline Poluição do Solo & 5 & 0 & 5 & 5 & 5 & 5 & 5 & 5 & 5 \\
\hline Total & 15 & 2,5 & 15 & 15 & 20 & 20 & 15 & 15 & 15 \\
\hline $\begin{array}{c}\text { Total } \\
\text { Ponderado }\end{array}$ & 5,0000 & 0,8333 & 5,0000 & 5,0000 & 6,6667 & 6,6667 & 5,0000 & 5,0000 & 5,0000 \\
\hline
\end{tabular}

Tabela A 7: Dimensão Social - Pontuações 2005

\begin{tabular}{|c|c|c|c|c|c|c|c|c|c|}
\hline & $\begin{array}{l}\text { Controla- } \\
\text { dor de } \\
\text { Demanda }\end{array}$ & $\begin{array}{l}\text { Ilumi- } \\
\text { nação }\end{array}$ & $\begin{array}{l}\text { Uso } \\
\text { Efici- } \\
\text { ente de } \\
\text { Motores } \\
\text { Elétricos }\end{array}$ & $\begin{array}{l}\text { Refrige- } \\
\text { ração } \\
\text { Eficiente }\end{array}$ & $\begin{array}{c}\text { Substitui- } \\
\text { ção } \\
\text { Veicular - } \\
\text { Diesel } \\
\text { por GNV }\end{array}$ & $\begin{array}{c}\text { Eficientiza- } \\
\text { ção de } \\
\text { Sistemas } \\
\text { de } \\
\text { Combustão }\end{array}$ & $\begin{array}{l}\text { Tarifas } \\
\text { Alter- } \\
\text { nativas }\end{array}$ & $\begin{array}{l}\text { Edifica- } \\
\text { ções } \\
\text { Efici- } \\
\text { entes }\end{array}$ & $\begin{array}{c}\text { Armaze- } \\
\text { namento } \\
\text { de } \\
\text { Energia }\end{array}$ \\
\hline $\begin{array}{c}\text { Efeitos do } \\
\text { desequilíbrio } \\
\text { ambiental no } \\
\text { meio social }\end{array}$ & 10 & 0 & 10 & 10 & 10 & 10 & 10 & 10 & 10 \\
\hline $\begin{array}{c}\text { Influência no } \\
\text { Mercado de } \\
\text { Trabalho - } \\
\text { Geração de } \\
\text { Empregos } \\
\end{array}$ & 0 & 5 & 5 & 5 & 5 & 5 & 0 & 0 & 0 \\
\hline $\begin{array}{c}\text { Considerações } \\
\text { funcionais e } \\
\text { estéticas de } \\
\text { Recursos }\end{array}$ & 0 & 5 & 10 & 0 & 5 & 10 & 0 & 0 & 0 \\
\hline Total & 20 & 30 & 60 & 40 & 50 & 60 & 20 & 20 & 20 \\
\hline $\begin{array}{c}\text { Total } \\
\text { Ponderado }\end{array}$ & 2,5000 & 3,7500 & 7,5000 & 5,0000 & 6,2500 & 7,5000 & 2,5000 & 2,5000 & 2,5000 \\
\hline
\end{tabular}


Tabela A 8: Dimensão Política - Pontuações 2005

\begin{tabular}{|c|c|c|c|c|c|c|c|c|c|}
\hline & $\begin{array}{l}\text { Controla- } \\
\text { dor de } \\
\text { Demanda }\end{array}$ & $\begin{array}{l}\text { Ilumi- } \\
\text { nação }\end{array}$ & $\begin{array}{c}\text { Uso } \\
\text { Efici- } \\
\text { ente de } \\
\text { Motores } \\
\text { Elétricos }\end{array}$ & $\begin{array}{l}\text { Refrige- } \\
\text { ração } \\
\text { Eficiente }\end{array}$ & $\begin{array}{c}\text { Substitui- } \\
\text { ção } \\
\text { Veicular - } \\
\text { Diesel } \\
\text { por GNV }\end{array}$ & $\begin{array}{c}\text { Eficientiza- } \\
\text { ção de } \\
\text { Sistemas } \\
\text { de } \\
\text { Combustão }\end{array}$ & $\begin{array}{l}\text { Tarifas } \\
\text { Alter- } \\
\text { nativas }\end{array}$ & $\begin{array}{l}\text { Edifica- } \\
\text { ções } \\
\text { Efici- } \\
\text { entes }\end{array}$ & $\begin{array}{c}\text { Armaze- } \\
\text { namento } \\
\text { de } \\
\text { Energia }\end{array}$ \\
\hline $\begin{array}{c}\text { Aceitação/Oposição } \\
\text { a Recursos do Lado } \\
\text { da Demanda }\end{array}$ & 0 & 5 & 5 & 5 & 0 & 5 & 0 & 0 & 0 \\
\hline $\begin{array}{c}\text { Apoio } \\
\text { Governamental }\end{array}$ & 5 & 5 & 5 & 5 & 5 & 5 & 5 & 5 & 5 \\
\hline $\begin{array}{l}\text { Conjunção e } \\
\text { Encontro de } \\
\text { Interesses }\end{array}$ & 0 & 5 & 5 & 5 & 0 & 5 & 0 & 0 & 0 \\
\hline $\begin{array}{c}\text { Risco a } \\
\text { Exposição } \\
\text { Cambial }\end{array}$ & 5 & 10 & 10 & 10 & 5 & 10 & 10 & 10 & 5 \\
\hline $\begin{array}{c}\text { Potencial } \\
\text { conscientização do } \\
\text { uso racional e } \\
\text { participação no } \\
\text { gerenciamento da } \\
\text { energia }\end{array}$ & 0 & 5 & $x$ & $x$ & $x$ & $x$ & 0 & $x$ & 0 \\
\hline Total & 20 & 95 & 75 & 75 & 20 & 75 & 35 & 35 & 20 \\
\hline $\begin{array}{c}\text { Total } \\
\text { Ponderado }\end{array}$ & 1,2500 & 5,9375 & 6,2500 & 6,2500 & 1,6667 & 6,2500 & 2,1875 & 2,9167 & 1,2500 \\
\hline
\end{tabular}


As Tabelas A9, A10, A11 e A12 a seguir exibem as pontuações recebidas por cada recurso energético em relação a cada atributo, nas quatro dimensões de análise. O segundo instante de avaliação é o ano de 2015. A conceituação da atribuição de pontuações para cada recurso energético é formalizada e trabalhada em detalhes na Dissertação de Mestrado de Boarati [70].

Tabela A 9: Dimensão Técnico-Econômica - Pontuações 2015

\begin{tabular}{|c|c|c|c|c|c|c|c|c|c|}
\hline & $\begin{array}{c}\text { Controla- } \\
\text { dor de } \\
\text { Demanda }\end{array}$ & $\begin{array}{l}\text { Ilumi- } \\
\text { nação }\end{array}$ & $\begin{array}{l}\text { Uso } \\
\text { Efici- } \\
\text { ente de } \\
\text { Motores } \\
\text { Elétricos }\end{array}$ & $\begin{array}{l}\text { Refrige- } \\
\text { ração } \\
\text { Eficiente }\end{array}$ & $\begin{array}{c}\text { Substitui- } \\
\text { ção } \\
\text { Veicular - } \\
\text { Diesel } \\
\text { por GNV }\end{array}$ & $\begin{array}{c}\text { Eficientiza- } \\
\text { ção de } \\
\text { Sistemas } \\
\text { de } \\
\text { Combustão }\end{array}$ & $\begin{array}{c}\text { Tarifas } \\
\text { Alter- } \\
\text { nativas }\end{array}$ & $\begin{array}{l}\text { Edifica- } \\
\text { ções } \\
\text { Efici- } \\
\text { entes }\end{array}$ & $\begin{array}{c}\text { Armaze- } \\
\text { namento } \\
\text { de } \\
\text { Energia }\end{array}$ \\
\hline $\begin{array}{c}\text { Custo do } \\
\text { Empreendimento } \\
\text { (US } \$ / M W)\end{array}$ & 7,5 & 2,5 & 7,5 & 7,5 & 7,5 & 2,5 & 10 & $x$ & 7,5 \\
\hline $\begin{array}{c}\text { Potencial } \\
\text { Relativo de GLD }\end{array}$ & 10 & 7,5 & 10 & 5 & 10 & 10 & 0 & 5 & 10 \\
\hline $\begin{array}{c}\text { Custo da } \\
\text { Energia } \\
\text { Economizada } \\
\text { (US\$/MWh) }\end{array}$ & $x$ & 5 & 5 & 7,5 & $x$ & 10 & $x$ & $\mathrm{x}$ & $\mathrm{x}$ \\
\hline $\begin{array}{l}\text { Incentivos } \\
\text { tarifários à } \\
\text { adoção de } \\
\text { programas de } \\
\text { GLD }\end{array}$ & 0 & 0 & 0 & 0 & $x$ & $x$ & $x$ & $\mathrm{x}$ & 0 \\
\hline $\begin{array}{c}\text { Tempo de } \\
\text { Implantação }\end{array}$ & 10 & 10 & 7,5 & 7,5 & 10 & 7,5 & 10 & 7,5 & 7,5 \\
\hline $\begin{array}{l}\text { Tempo de } \\
\text { Retorno do } \\
\text { Investimento }\end{array}$ & 10 & 5 & 5 & 5 & 10 & 0 & 0 & $x$ & 7,5 \\
\hline $\begin{array}{c}\text { Domínio } \\
\text { Tecnológico } \\
\end{array}$ & 10 & 10 & 10 & 10 & 10 & 7,5 & 7,5 & 10 & 7,5 \\
\hline $\begin{array}{c}\text { Grau de } \\
\text { Necessidade de } \\
\text { Monitoração e } \\
\text { Manutenção }\end{array}$ & 0 & 10 & 2,5 & 2,5 & 10 & 5 & 0 & 10 & 0 \\
\hline $\begin{array}{l}\text { Qualidade da } \\
\text { Energia } \\
\text { gerenciada }\end{array}$ & 5 & 5 & 10 & 10 & $x$ & $x$ & 5 & 5 & 5 \\
\hline $\begin{array}{l}\text { Estrutura de } \\
\text { Marketing e } \\
\text { Propaganda } \\
\text { Estratégica }\end{array}$ & 5 & 10 & 5 & 5 & 10 & 5 & 5 & 5 & 5 \\
\hline Total & 150 & 167,5 & 162,5 & 167,5 & 180 & 122,5 & 102,5 & 100 & 127,5 \\
\hline $\begin{array}{c}\text { Total } \\
\text { Ponderado }\end{array}$ & 6,2500 & 5,9821 & 5,8036 & 5,9821 & 9,4737 & 5,3261 & 4,8810 & 7,6923 & 5,3125 \\
\hline
\end{tabular}


Tabela A 10: Dimensão Ambiental - Pontuações 2015

\begin{tabular}{|c|r|r|r|r|r|r|r|r|}
\hline & $\begin{array}{c}\text { Controla- } \\
\text { dor de } \\
\text { Demanda }\end{array}$ & $\begin{array}{c}\text { Ilumi- } \\
\text { nação }\end{array}$ & $\begin{array}{c}\text { Uso } \\
\text { Efici- } \\
\text { ente de } \\
\text { Motores } \\
\text { Elétricos }\end{array}$ & $\begin{array}{c}\text { Refrige- } \\
\text { ração } \\
\text { Eficiente }\end{array}$ & $\begin{array}{c}\text { Substitui- } \\
\text { ção } \\
\text { Veicular - } \\
\text { Diesel } \\
\text { por GNV }\end{array}$ & $\begin{array}{c}\text { Eficientiza- } \\
\text { ção de } \\
\text { Sistemas } \\
\text { de } \\
\text { Combustão }\end{array}$ & $\begin{array}{c}\text { Tarifas } \\
\text { Alter- } \\
\text { nativas }\end{array}$ & $\begin{array}{c}\text { Edifica- } \\
\text { ções } \\
\text { Efici- } \\
\text { entes }\end{array}$ \\
$\begin{array}{c}\text { Armaze- } \\
\text { namento } \\
\text { de } \\
\text { Energia }\end{array}$ \\
$\begin{array}{c}\text { Poluição } \\
\text { Atmosférica }\end{array}$
\end{tabular}

Tabela A 11: Dimensão Social - Pontuações 2015

\begin{tabular}{|c|c|c|c|c|c|c|c|c|c|}
\hline & $\begin{array}{l}\text { Controla- } \\
\text { dor de } \\
\text { Demanda }\end{array}$ & $\begin{array}{l}\text { Ilumi- } \\
\text { nação }\end{array}$ & $\begin{array}{c}\text { Uso } \\
\text { Efici- } \\
\text { ente de } \\
\text { Motores } \\
\text { Elétricos }\end{array}$ & $\begin{array}{l}\text { Refrige- } \\
\text { ração } \\
\text { Eficiente }\end{array}$ & $\begin{array}{l}\text { Substitui- } \\
\text { ção } \\
\text { Veicular - } \\
\text { Diesel } \\
\text { por GNV }\end{array}$ & $\begin{array}{l}\text { Eficientiza- } \\
\text { ção de } \\
\text { Sistemas } \\
\text { de } \\
\text { Combustão }\end{array}$ & $\begin{array}{l}\text { Tarifas } \\
\text { Alter- } \\
\text { nativas }\end{array}$ & $\begin{array}{l}\text { Edifica- } \\
\text { ções } \\
\text { Efici- } \\
\text { entes }\end{array}$ & $\begin{array}{c}\text { Armaze- } \\
\text { namento } \\
\text { de } \\
\text { Energia }\end{array}$ \\
\hline $\begin{array}{c}\text { Efeitos do } \\
\text { desequilíbrio } \\
\text { ambiental no } \\
\text { meio social }\end{array}$ & 10 & 0 & 10 & 10 & 10 & 10 & 10 & 10 & 10 \\
\hline $\begin{array}{c}\text { Influência no } \\
\text { Mercado de } \\
\text { Trabalho - } \\
\text { Geração de } \\
\text { Empregos }\end{array}$ & 5 & 5 & 5 & 5 & 10 & 5 & 0 & 5 & 5 \\
\hline $\begin{array}{l}\text { Considerações } \\
\text { funcionais e } \\
\text { estéticas de } \\
\text { Recursos }\end{array}$ & 0 & 5 & 10 & 0 & 5 & 10 & 0 & 0 & 0 \\
\hline Total & 40 & 30 & 60 & 40 & 70 & 60 & 20 & 40 & 40 \\
\hline $\begin{array}{c}\text { Total } \\
\text { Ponderado }\end{array}$ & 5,0000 & 3,7500 & 7,5000 & 5,0000 & 8,7500 & 7,5000 & 2,5000 & 5,0000 & 5,0000 \\
\hline
\end{tabular}


Tabela A 12: Dimensão Política - Pontuações 2015

\begin{tabular}{|c|c|c|c|c|c|c|c|c|c|}
\hline & $\begin{array}{l}\text { Controla- } \\
\text { dor de } \\
\text { Demanda }\end{array}$ & $\begin{array}{l}\text { Ilumi- } \\
\text { nação }\end{array}$ & $\begin{array}{c}\text { Uso } \\
\text { Efici- } \\
\text { ente de } \\
\text { Motores } \\
\text { Elétricos }\end{array}$ & $\begin{array}{l}\text { Refrige- } \\
\text { ração } \\
\text { Eficiente }\end{array}$ & $\begin{array}{c}\text { Substitui- } \\
\text { ção } \\
\text { Veicular - } \\
\text { Diesel } \\
\text { por GNV }\end{array}$ & $\begin{array}{c}\text { Eficientiza- } \\
\text { ção de } \\
\text { Sistemas } \\
\text { de } \\
\text { Combustão }\end{array}$ & $\begin{array}{l}\text { Tarifas } \\
\text { Alter- } \\
\text { nativas }\end{array}$ & $\begin{array}{l}\text { Edifica- } \\
\text { ções } \\
\text { Efici- } \\
\text { entes }\end{array}$ & $\begin{array}{l}\text { Armaze- } \\
\text { namento } \\
\text { de } \\
\text { Energia }\end{array}$ \\
\hline $\begin{array}{c}\text { Aceitação/Oposição } \\
\text { a Recursos do Lado } \\
\text { da Demanda }\end{array}$ & 0 & 5 & 5 & 5 & 0 & 5 & 0 & 0 & 0 \\
\hline $\begin{array}{c}\text { Apoio } \\
\text { Governamental }\end{array}$ & 5 & 5 & 5 & 5 & 5 & 5 & 5 & 5 & 5 \\
\hline $\begin{array}{l}\text { Conjunção e } \\
\text { Encontro de } \\
\text { Interesses }\end{array}$ & 0 & 5 & 5 & 5 & 0 & 5 & 0 & 0 & 0 \\
\hline $\begin{array}{c}\text { Risco a } \\
\text { Exposição } \\
\text { Cambial }\end{array}$ & 5 & 10 & 10 & 10 & 5 & 10 & 10 & 10 & 5 \\
\hline $\begin{array}{c}\text { Potencial } \\
\text { conscientização do } \\
\text { uso racional e } \\
\text { participação no } \\
\text { gerenciamento da } \\
\text { energia }\end{array}$ & 0 & 5 & $x$ & $x$ & $x$ & $x$ & 0 & $x$ & 0 \\
\hline Total & 20 & 95 & 75 & 75 & 20 & 75 & 35 & 35 & 65 \\
\hline $\begin{array}{c}\text { Total } \\
\text { Ponderado }\end{array}$ & 1,2500 & 5,9375 & 6,2500 & 6,2500 & 1,6667 & 6,2500 & 2,1875 & 2,9167 & 4,0625 \\
\hline
\end{tabular}


As Tabelas A13, A14, A15 e A16 a seguir exibem as pontuações recebidas por cada recurso energético em relação a cada atributo, nas quatro dimensões de análise. O terceiro instante de avaliação é o ano de 2025. A conceituação da atribuição de pontuações para cada recurso energético é formalizada e trabalhada em detalhes na Dissertação de Mestrado de Boarati [70].

Tabela A 13: Dimensão Técnico-Econômica - Pontuações 2025

\begin{tabular}{|c|c|c|c|c|c|c|c|c|c|}
\hline & $\begin{array}{l}\text { Controla- } \\
\text { dor de } \\
\text { Demanda }\end{array}$ & $\begin{array}{l}\text { Ilumi- } \\
\text { nação }\end{array}$ & $\begin{array}{l}\text { Uso } \\
\text { Efici- } \\
\text { ente de } \\
\text { Motores } \\
\text { Elétricos }\end{array}$ & $\begin{array}{l}\text { Refrige- } \\
\text { ração } \\
\text { Eficiente }\end{array}$ & $\begin{array}{c}\text { Substitui- } \\
\text { ção } \\
\text { Veicular - } \\
\text { Diesel } \\
\text { por GNV }\end{array}$ & \begin{tabular}{|c|} 
Eficientiza- \\
ção de \\
Sistemas \\
de \\
Combustão
\end{tabular} & $\begin{array}{l}\text { Tarifas } \\
\text { Alter- } \\
\text { nativas }\end{array}$ & $\begin{array}{l}\text { Edifica- } \\
\text { ções } \\
\text { Efici- } \\
\text { entes }\end{array}$ & $\begin{array}{c}\text { Armaze- } \\
\text { namento } \\
\text { de } \\
\text { Energia }\end{array}$ \\
\hline $\begin{array}{c}\text { Custo do } \\
\text { Empreendimento } \\
\text { (US\$/MW) }\end{array}$ & 10 & 5 & 10 & 10 & 10 & 5 & 10 & $x$ & 10 \\
\hline $\begin{array}{c}\text { Potencial } \\
\text { Relativo de GLD }\end{array}$ & 10 & 7,5 & 10 & 5 & 10 & 10 & 5 & 5 & 10 \\
\hline $\begin{array}{c}\text { Custo da } \\
\text { Energia } \\
\text { Economizada } \\
\text { (US\$/MWh) }\end{array}$ & $x$ & 7,5 & 7,5 & 10 & $x$ & 10 & $x$ & $x$ & $x$ \\
\hline $\begin{array}{c}\text { Incentivos } \\
\text { tarifários à } \\
\text { adoção de } \\
\text { programas de } \\
\text { GLD }\end{array}$ & 10 & 5 & 5 & 5 & $x$ & $x$ & $x$ & $x$ & 10 \\
\hline $\begin{array}{c}\text { Tempo de } \\
\text { Implantação }\end{array}$ & 10 & 10 & 10 & 10 & 10 & 10 & 10 & 10 & 10 \\
\hline $\begin{array}{c}\text { Tempo de } \\
\text { Retorno do } \\
\text { Investimento }\end{array}$ & 10 & 7,5 & 7,5 & 5 & 10 & 5 & 5 & $x$ & 7,5 \\
\hline $\begin{array}{c}\text { Domínio } \\
\text { Tecnológico }\end{array}$ & 10 & 10 & 10 & 10 & 10 & 10 & 10 & 10 & 10 \\
\hline $\begin{array}{l}\text { Grau de } \\
\text { Necessidade de } \\
\text { Monitoração e } \\
\text { Manutenção }\end{array}$ & 0 & 10 & 2,5 & 2,5 & 10 & 5 & 0 & 10 & 0 \\
\hline $\begin{array}{c}\text { Qualidade da } \\
\text { Energia } \\
\text { gerenciada } \\
\end{array}$ & 5 & 5 & 10 & 10 & $x$ & $x$ & 5 & 5 & 5 \\
\hline $\begin{array}{l}\text { Estrutura de } \\
\text { Marketing e } \\
\text { Propaganda } \\
\text { Estratégica }\end{array}$ & 10 & 10 & 10 & 10 & 10 & 10 & 10 & 10 & 10 \\
\hline Total & 200 & 212,5 & 222,5 & 217,5 & 190 & 175 & 145 & 115 & 190 \\
\hline $\begin{array}{c}\text { Total } \\
\text { Ponderado }\end{array}$ & 8,3333 & 7,5893 & 7,9464 & 7,7679 & 10,0000 & 7,6087 & 6,9048 & 8,8462 & 7,9167 \\
\hline
\end{tabular}


Tabela A 14: Dimensão Ambiental - Pontuações 2025

\begin{tabular}{|c|c|c|c|c|c|c|c|c|c|}
\hline & $\begin{array}{l}\text { Controla- } \\
\text { dor de } \\
\text { Demanda }\end{array}$ & $\begin{array}{l}\text { Ilumi- } \\
\text { nação }\end{array}$ & $\begin{array}{c}\text { Uso } \\
\text { Efici- } \\
\text { ente de } \\
\text { Motores } \\
\text { Elétricos }\end{array}$ & $\begin{array}{l}\text { Refrige- } \\
\text { ração } \\
\text { Eficiente }\end{array}$ & $\begin{array}{c}\text { Substitui- } \\
\text { ção } \\
\text { Veicular - } \\
\text { Diesel } \\
\text { por GNV }\end{array}$ & $\begin{array}{c}\text { Eficientiza- } \\
\text { ção de } \\
\text { Sistemas } \\
\text { de } \\
\text { Combustão }\end{array}$ & $\begin{array}{c}\text { Tarifas } \\
\text { Alter- } \\
\text { nativas }\end{array}$ & $\begin{array}{l}\text { Edifica- } \\
\text { ções } \\
\text { Efici- } \\
\text { entes }\end{array}$ & $\begin{array}{c}\text { Armaze- } \\
\text { namento } \\
\text { de } \\
\text { Energia }\end{array}$ \\
\hline $\begin{array}{c}\text { Poluição } \\
\text { Atmosférica } \\
\end{array}$ & 5 & 2,5 & 5 & 5 & 10 & 7,5 & 5 & 5 & 5 \\
\hline $\begin{array}{c}\text { Poluição das } \\
\text { Águas }\end{array}$ & 5 & 2,5 & 5 & 5 & 5 & 7,5 & 5 & 5 & 5 \\
\hline Poluição do Solo & 5 & 2,5 & 5 & 5 & 5 & 5 & 5 & 5 & 5 \\
\hline Total & 15 & 7,5 & 15 & 15 & 20 & 20 & 15 & 15 & 15 \\
\hline $\begin{array}{c}\text { Total } \\
\text { Ponderado }\end{array}$ & 5,0000 & 2,5000 & 5,0000 & 5,0000 & 6,6667 & 6,6667 & 5,0000 & 5,0000 & 5,0000 \\
\hline
\end{tabular}

Tabela A 15: Dimensão Social - Pontuações 2025

\begin{tabular}{|c|c|c|c|c|c|c|c|c|c|}
\hline & $\begin{array}{l}\text { Controla- } \\
\text { dor de } \\
\text { Demanda }\end{array}$ & $\begin{array}{l}\text { Ilumi- } \\
\text { nação }\end{array}$ & $\begin{array}{l}\text { Uso } \\
\text { Efici- } \\
\text { ente de } \\
\text { Motores } \\
\text { Elétricos }\end{array}$ & $\begin{array}{l}\text { Refrige- } \\
\text { ração } \\
\text { Eficiente }\end{array}$ & $\begin{array}{l}\text { Substitui- } \\
\text { ção } \\
\text { Veicular - } \\
\text { Diesel } \\
\text { por GNV }\end{array}$ & $\begin{array}{l}\text { Eficientiza- } \\
\text { ção de } \\
\text { Sistemas } \\
\text { de } \\
\text { Combustão }\end{array}$ & $\begin{array}{l}\text { Tarifas } \\
\text { Alter- } \\
\text { nativas }\end{array}$ & $\begin{array}{l}\text { Edifica- } \\
\text { ções } \\
\text { Efici- } \\
\text { entes }\end{array}$ & $\begin{array}{l}\text { Armaze- } \\
\text { namento } \\
\text { de } \\
\text { Energia }\end{array}$ \\
\hline $\begin{array}{c}\text { Efeitos do } \\
\text { desequilíbrio } \\
\text { ambiental no } \\
\text { meio social }\end{array}$ & 10 & 0 & 10 & 10 & 10 & 10 & 10 & 10 & 10 \\
\hline $\begin{array}{c}\text { Influência no } \\
\text { Mercado de } \\
\text { Trabalho - } \\
\text { Geração de } \\
\text { Empregos } \\
\end{array}$ & 5 & 5 & 5 & 5 & 10 & 5 & 0 & 5 & 5 \\
\hline $\begin{array}{c}\text { Considerações } \\
\text { funcionais e } \\
\text { estéticas de } \\
\text { Recursos }\end{array}$ & 5 & 5 & 10 & 5 & 5 & 10 & 5 & 5 & 5 \\
\hline Total & 50 & 30 & 60 & 50 & 70 & 60 & 30 & 50 & 50 \\
\hline $\begin{array}{c}\text { Total } \\
\text { Ponderado }\end{array}$ & 6,2500 & 3,7500 & 7,5000 & 6,2500 & 8,7500 & 7,5000 & 3,7500 & 6,2500 & 6,2500 \\
\hline
\end{tabular}


Tabela A 16: Dimensão Política - Pontuações 2025

\begin{tabular}{|c|c|c|c|c|c|c|c|c|c|}
\hline & $\begin{array}{l}\text { Controla- } \\
\text { dor de } \\
\text { Demanda }\end{array}$ & $\begin{array}{l}\text { Ilumi- } \\
\text { nação }\end{array}$ & $\begin{array}{c}\text { Uso } \\
\text { Efici- } \\
\text { ente de } \\
\text { Motores } \\
\text { Elétricos }\end{array}$ & $\begin{array}{l}\text { Refrige- } \\
\text { ração } \\
\text { Eficiente }\end{array}$ & $\begin{array}{c}\text { Substitui- } \\
\text { ção } \\
\text { Veicular - } \\
\text { Diesel } \\
\text { por GNV }\end{array}$ & $\begin{array}{l}\text { Eficientiza- } \\
\text { ção de } \\
\text { Sistemas } \\
\text { de } \\
\text { Combustão }\end{array}$ & $\begin{array}{l}\text { Tarifas } \\
\text { Alter- } \\
\text { nativas }\end{array}$ & $\begin{array}{l}\text { Edifica- } \\
\text { ções } \\
\text { Efici- } \\
\text { entes }\end{array}$ & $\begin{array}{c}\text { Armaze- } \\
\text { namento } \\
\text { de } \\
\text { Energia }\end{array}$ \\
\hline $\begin{array}{c}\text { Aceitação/Oposição } \\
\text { a Recursos do Lado } \\
\text { da Demanda }\end{array}$ & 5 & 10 & 10 & 10 & 7,5 & 10 & 5 & 5 & 5 \\
\hline $\begin{array}{c}\text { Apoio } \\
\text { Governamental }\end{array}$ & 7,5 & 7,5 & 7,5 & 7,5 & 7,5 & 7,5 & 7,5 & 7,5 & 7,5 \\
\hline $\begin{array}{l}\text { Conjunção e } \\
\text { Encontro de } \\
\text { Interesses }\end{array}$ & 7,5 & 7,5 & 7,5 & 7,5 & 7,5 & 7,5 & 5 & 5 & 5 \\
\hline $\begin{array}{c}\text { Risco a } \\
\text { Exposição } \\
\text { Cambial }\end{array}$ & 5 & 10 & 10 & 10 & 5 & 10 & 10 & 10 & 5 \\
\hline $\begin{array}{c}\text { Potencial } \\
\text { conscientização do } \\
\text { uso racional e } \\
\text { participação no } \\
\text { gerenciamento da } \\
\text { energia } \\
\end{array}$ & 5 & 7,5 & 10 & $x$ & $x$ & $x$ & 5 & $x$ & 5 \\
\hline Total & 90 & 140 & 110 & 110 & 82,5 & 110 & 97,5 & 77,5 & 82,5 \\
\hline $\begin{array}{c}\text { Total } \\
\text { Ponderado }\end{array}$ & 5,6250 & 8,7500 & 9,1667 & 9,1667 & 6,8750 & 9,1667 & 6,0938 & 6,4583 & 5,1563 \\
\hline
\end{tabular}


As Tabelas A17, A18, A19 e A20 a seguir exibem as pontuações recebidas por cada recurso energético em relação a cada atributo, nas quatro dimensões de análise. O último instante de avaliação é o ano de 2035. A conceituação da atribuição de pontuações para cada recurso energético é formalizada e trabalhada em detalhes na Dissertação de Mestrado de Boarati [70].

Tabela A 17: Dimensão Técnico-Econômica - Pontuações 2035

\begin{tabular}{|c|c|c|c|c|c|c|c|c|c|}
\hline & $\begin{array}{l}\text { Controla- } \\
\text { dor de } \\
\text { Demanda }\end{array}$ & $\begin{array}{l}\text { Ilumi- } \\
\text { nação }\end{array}$ & $\begin{array}{l}\text { Uso } \\
\text { Efici- } \\
\text { ente de } \\
\text { Motores } \\
\text { Elétricos }\end{array}$ & $\begin{array}{l}\text { Refrige- } \\
\text { ração } \\
\text { Eficiente }\end{array}$ & $\begin{array}{c}\text { Substitui- } \\
\text { ção } \\
\text { Veicular - } \\
\text { Diesel } \\
\text { por GNV }\end{array}$ & \begin{tabular}{|c|} 
Eficientiza- \\
ção de \\
Sistemas \\
de \\
Combustão
\end{tabular} & $\begin{array}{l}\text { Tarifas } \\
\text { Alter- } \\
\text { nativas }\end{array}$ & $\begin{array}{l}\text { Edifica- } \\
\text { ções } \\
\text { Efici- } \\
\text { entes }\end{array}$ & $\begin{array}{c}\text { Armaze- } \\
\text { namento } \\
\text { de } \\
\text { Energia }\end{array}$ \\
\hline $\begin{array}{c}\text { Custo do } \\
\text { Empreendimento } \\
\text { (US\$/MW) }\end{array}$ & 10 & 5 & 10 & 10 & 10 & 5 & 10 & $x$ & 10 \\
\hline $\begin{array}{c}\text { Potencial } \\
\text { Relativo de GLD }\end{array}$ & 10 & 7,5 & 10 & 5 & 10 & 10 & 5 & 5 & 10 \\
\hline $\begin{array}{c}\text { Custo da } \\
\text { Energia } \\
\text { Economizada } \\
\text { (US\$/MWh) }\end{array}$ & $x$ & 10 & 10 & 10 & $x$ & 10 & $x$ & $x$ & $x$ \\
\hline $\begin{array}{c}\text { Incentivos } \\
\text { tarifários à } \\
\text { adoção de } \\
\text { programas de } \\
\text { GLD }\end{array}$ & 10 & 5 & 5 & 5 & $x$ & $x$ & $x$ & $x$ & 10 \\
\hline $\begin{array}{c}\text { Tempo de } \\
\text { Implantação }\end{array}$ & 10 & 10 & 10 & 10 & 10 & 10 & 10 & 10 & 10 \\
\hline $\begin{array}{c}\text { Tempo de } \\
\text { Retorno do } \\
\text { Investimento }\end{array}$ & 10 & 7,5 & 7,5 & 5 & 10 & 5 & 5 & $x$ & 7,5 \\
\hline $\begin{array}{c}\text { Domínio } \\
\text { Tecnológico }\end{array}$ & 10 & 10 & 10 & 10 & 10 & 10 & 10 & 10 & 10 \\
\hline $\begin{array}{l}\text { Grau de } \\
\text { Necessidade de } \\
\text { Monitoração e } \\
\text { Manutenção }\end{array}$ & 0 & 10 & 2,5 & 2,5 & 10 & 5 & 0 & 10 & 0 \\
\hline $\begin{array}{c}\text { Qualidade da } \\
\text { Energia } \\
\text { gerenciada } \\
\end{array}$ & 5 & 5 & 10 & 10 & $x$ & $x$ & 5 & 5 & 5 \\
\hline $\begin{array}{l}\text { Estrutura de } \\
\text { Marketing e } \\
\text { Propaganda } \\
\text { Estratégica }\end{array}$ & 10 & 10 & 10 & 10 & 10 & 10 & 10 & 10 & 10 \\
\hline Total & 200 & 222,5 & 232,5 & 217,5 & 190 & 175 & 145 & 115 & 190 \\
\hline $\begin{array}{c}\text { Total } \\
\text { Ponderado }\end{array}$ & 8,3333 & 7,9464 & 8,3036 & 7,7679 & 10,0000 & 7,6087 & 6,9048 & 8,8462 & 7,9167 \\
\hline
\end{tabular}


Tabela A 18: Dimensão Ambiental - Pontuações 2035

\begin{tabular}{|c|c|c|c|c|c|c|c|c|c|}
\hline & $\begin{array}{l}\text { Controla- } \\
\text { dor de } \\
\text { Demanda }\end{array}$ & $\begin{array}{l}\text { Ilumi- } \\
\text { nação }\end{array}$ & $\begin{array}{c}\text { Uso } \\
\text { Efici- } \\
\text { ente de } \\
\text { Motores } \\
\text { Elétricos }\end{array}$ & $\begin{array}{l}\text { Refrige- } \\
\text { ração } \\
\text { Eficiente }\end{array}$ & $\begin{array}{c}\text { Substitui- } \\
\text { ção } \\
\text { Veicular - } \\
\text { Diesel } \\
\text { por GNV }\end{array}$ & $\begin{array}{c}\text { Eficientiza- } \\
\text { ção de } \\
\text { Sistemas } \\
\text { de } \\
\text { Combustão }\end{array}$ & $\begin{array}{c}\text { Tarifas } \\
\text { Alter- } \\
\text { nativas }\end{array}$ & $\begin{array}{l}\text { Edifica- } \\
\text { ções } \\
\text { Efici- } \\
\text { entes }\end{array}$ & $\begin{array}{c}\text { Armaze- } \\
\text { namento } \\
\text { de } \\
\text { Energia }\end{array}$ \\
\hline $\begin{array}{c}\text { Poluição } \\
\text { Atmosférica } \\
\end{array}$ & 5 & 5 & 5 & 5 & 10 & 7,5 & 5 & 5 & 5 \\
\hline $\begin{array}{c}\text { Poluição das } \\
\text { Águas }\end{array}$ & 5 & 5 & 5 & 5 & 5 & 7,5 & 5 & 5 & 5 \\
\hline Poluição do Solo & 5 & 5 & 5 & 5 & 5 & 5 & 5 & 5 & 5 \\
\hline Total & 15 & 15 & 15 & 15 & 20 & 20 & 15 & 15 & 15 \\
\hline $\begin{array}{c}\text { Total } \\
\text { Ponderado }\end{array}$ & 5,0000 & 5,0000 & 5,0000 & 5,0000 & 6,6667 & 6,6667 & 5,0000 & 5,0000 & 5,0000 \\
\hline
\end{tabular}

Tabela A 19: Dimensão Social - Pontuações 2035

\begin{tabular}{|c|c|c|c|c|c|c|c|c|c|}
\hline & $\begin{array}{l}\text { Controla- } \\
\text { dor de } \\
\text { Demanda }\end{array}$ & $\begin{array}{l}\text { Ilumi- } \\
\text { nação }\end{array}$ & $\begin{array}{l}\text { Uso } \\
\text { Efici- } \\
\text { ente de } \\
\text { Motores } \\
\text { Elétricos }\end{array}$ & $\begin{array}{l}\text { Refrige- } \\
\text { ração } \\
\text { Eficiente }\end{array}$ & $\begin{array}{l}\text { Substitui- } \\
\text { ção } \\
\text { Veicular - } \\
\text { Diesel } \\
\text { por GNV }\end{array}$ & $\begin{array}{l}\text { Eficientiza- } \\
\text { ção de } \\
\text { Sistemas } \\
\text { de } \\
\text { Combustão }\end{array}$ & $\begin{array}{l}\text { Tarifas } \\
\text { Alter- } \\
\text { nativas }\end{array}$ & $\begin{array}{l}\text { Edifica- } \\
\text { ções } \\
\text { Efici- } \\
\text { entes }\end{array}$ & $\begin{array}{l}\text { Armaze- } \\
\text { namento } \\
\text { de } \\
\text { Energia }\end{array}$ \\
\hline $\begin{array}{c}\text { Efeitos do } \\
\text { desequilíbrio } \\
\text { ambiental no } \\
\text { meio social }\end{array}$ & 10 & 0 & 10 & 10 & 10 & 10 & 10 & 10 & 10 \\
\hline $\begin{array}{c}\text { Influência no } \\
\text { Mercado de } \\
\text { Trabalho - } \\
\text { Geração de } \\
\text { Empregos } \\
\end{array}$ & 5 & 5 & 5 & 5 & 10 & 5 & 0 & 5 & 5 \\
\hline $\begin{array}{c}\text { Considerações } \\
\text { funcionais e } \\
\text { estéticas de } \\
\text { Recursos }\end{array}$ & 10 & 10 & 10 & 10 & 10 & 10 & 10 & 10 & 10 \\
\hline Total & 60 & 40 & 60 & 60 & 80 & 60 & 40 & 60 & 60 \\
\hline $\begin{array}{c}\text { Total } \\
\text { Ponderado }\end{array}$ & 7,5000 & 5,0000 & 7,5000 & 7,5000 & 10,0000 & 7,5000 & 5,0000 & 7,5000 & 7,5000 \\
\hline
\end{tabular}


Tabela A 20: Dimensão Política - Pontuações 2035

\begin{tabular}{|c|c|c|c|c|c|c|c|c|c|}
\hline & $\begin{array}{l}\text { Controla- } \\
\text { dor de } \\
\text { Demanda }\end{array}$ & $\begin{array}{l}\text { Ilumi- } \\
\text { nação }\end{array}$ & $\begin{array}{c}\text { Uso } \\
\text { Efici- } \\
\text { ente de } \\
\text { Motores } \\
\text { Elétricos }\end{array}$ & $\begin{array}{l}\text { Refrige- } \\
\text { ração } \\
\text { Eficiente }\end{array}$ & $\begin{array}{l}\text { Substitui- } \\
\text { ção } \\
\text { Veicular - } \\
\text { Diesel } \\
\text { por GNV }\end{array}$ & $\begin{array}{l}\text { Eficientiza- } \\
\text { ção de } \\
\text { Sistemas } \\
\text { de } \\
\text { Combustão }\end{array}$ & $\begin{array}{l}\text { Tarifas } \\
\text { Alter- } \\
\text { nativas }\end{array}$ & $\begin{array}{l}\text { Edifica- } \\
\text { ções } \\
\text { Efici- } \\
\text { entes }\end{array}$ & $\begin{array}{c}\text { Armaze- } \\
\text { namento } \\
\text { de } \\
\text { Energia }\end{array}$ \\
\hline $\begin{array}{c}\text { Aceitação/Oposição } \\
\text { a Recursos do Lado } \\
\text { da Demanda }\end{array}$ & 5 & 10 & 10 & 10 & 10 & 10 & 5 & 5 & 5 \\
\hline $\begin{array}{c}\text { Apoio } \\
\text { Governamental }\end{array}$ & 10 & 10 & 10 & 10 & 10 & 7,5 & 10 & 10 & 10 \\
\hline $\begin{array}{l}\text { Conjunção e } \\
\text { Encontro de } \\
\text { Interesses }\end{array}$ & 10 & 10 & 10 & 10 & 10 & 10 & 5 & 5 & 5 \\
\hline $\begin{array}{l}\text { Risco a } \\
\text { Exposição } \\
\text { Cambial }\end{array}$ & 5 & 10 & 10 & 10 & 5 & 10 & 10 & 10 & 5 \\
\hline $\begin{array}{c}\text { Potencial } \\
\text { conscientização do } \\
\text { uso racional e } \\
\text { participação no } \\
\text { gerenciamento da } \\
\text { energia }\end{array}$ & 10 & 10 & 10 & $x$ & $x$ & $x$ & 10 & $x$ & 10 \\
\hline Total & 120 & 160 & 120 & 120 & 105 & 117,5 & 120 & 80 & 105 \\
\hline $\begin{array}{c}\text { Total } \\
\text { Ponderado }\end{array}$ & 7,5000 & 10,0000 & 10,0000 & 10,0000 & 8,7500 & 9,7917 & 7,5000 & 6,6667 & 6,5625 \\
\hline
\end{tabular}




\section{Referências Bibliográficas}

[1] UDAETA, M.E.M . "Planejamento Integrado de Recursos Energéticos - PIR para o Setor Elétrico (pensando o Desenvolvimento Sustentável)" , São Paulo, 1997. 351 p. Tese de Doutorado. Departamento de Energia e Automação da Escola Politécnica da Universidade de São Paulo.

[2] UDAETA, M.E.M., et al. "Sistema de Análise Energética para os Usos Finais no Estado de São Paulo" Proposta de Trabalho para SESP e CTEEP. São Paulo, 2005.

[3] Internacional Institute for Sustainable Development. "Sustaining Excellence: The 2004-2005 Annual Report of the International Institute for Sustainable Development" Homepage: http://www.iisd.org/. Setembro, 2005.

[4] UDAETA, M.E.M., GALVÃO, L.C.R., GRIMONI, J.A.B. "Iniciação a Conceitos de Sistemas Energéticos para o Desenvolvimento Limpo", Edusp. São Paulo, 2004.

[5] REIS, L. B.; SILVEIRA, S. (2000). "Energia Elétrica para um Desenvolvimento Sustentável." Editora da Universidade de São Paulo - Edusp, São Paulo, 2000.

[6] GIMENES, A.L.V. "Modelo de Integração de Recursos como Instrumento para um Planejamento Energético Sustentável”. São Paulo, 2004. 202p. Tese de Doutorado. Departamento de Energia e Automação da Escola Politécnica da Universidade de São Paulo.

[7] World Comission on Environment and Development. "Our Common Future", 1987. 
[8] GELLINGS \& CHAMBERLIN “Demand Side Management Concepts \& Methods" Fairmont Press, Inc. Lilburn, USA, 1992.

[9] CAMPOS, A. "Gerenciamento Pelo Lado da Demanda: Um Estudo de Caso". Dissertação de Mestrado apresentada ao Programa Interunidades (IEE/POLI/FEA), São Paulo, 2004.

[10] CAMARGO, C. C. B. “Gerenciamento pelo Lado da Demanda: Metodologia para Identificação do Potencial de Conservação de Energia Elétrica de Consumidores Residenciais”. Tese de Doutorado - UFSC. Brasil, 1996.

[11] COSTA, C.V. , ROVERE, E. L. "Oportunidades de Negócios em Segmentos Produtivos Nacionais". Caderno do Núcleo de Assuntos Estratégicos - NAE Mudança do Clima, Parte III B. Brasília, 2005.

[12] CONPET - Programa Nacional de Uso Racional de Derivados de Petróleo e de Gás Natural. “O CONPET apresenta seus resultados”. Rio de Janeiro, 2004.

[13] LEONELLI, P.A. “Uso Efiiciente de Energia Elétrica no Setor Residencial: Uma Análise do Comportamento do Consumidor". Dissertação de Mestrado em Planejamento Energético - Universidade Federal do Rio de Janeiro. Rio de Janeiro, 1999.

[14] FBOMS - Fórum Brasileiro de ONGs e Movimentos Sociais para o Meio Ambiente e o Desenvolvimento. "O Velho 'Novo Modelo' do Setor Elétrico Brasileiro". Jornal de Desenvolvimento Sustentável e Meio Ambiente. 2003. 
[15] UDAETA, M.E.M., GRIMONI, J.A.B. "Modelo Institucional do Setor Elétrico" Relatório Técnico. Departamento de Energia e Automação da Escola Politécnica da Universidade de São Paulo. São Paulo, 2004.

[16] MARQUES, M.J. "A Morte do GLD”, Coluna da Revista Canal Energia. Homepage: http//:www.canalenergia.com.br. Agosto, 2005.

[17] D’ÁVILA, M. "A eficiência é o maior, mais barato e mais seguro recurso energético do Brasil", Ministério do Meio Ambiente. Homepage: http://www.ambiente.gov.br. Agosto, 2005

[18] CARVAlHO, C.E., REIS, L.B. "A Análise do Ciclo de Vida e os Custos Completos no Planejamento Energético". Dissertação de Mestrado. Departamento de Energia e Automação da Escola Politécnica da Universidade de São Paulo. São Paulo, 2000.

[19] ELETROBRÁS/PROCEL - “Conservação de Energia - Eficiência Energética de Instalações e Equipamentos"- Itajubá, 2001. 467 p. Escola Federal de Engenharia de Itajubá.

[20] SAUER, I. "Estudo de Planejamento Integrado de Recursos para o Sistema Elétrico de Boa Vista RR". Instituto de Eletrotecnia e Energia da Universidade de São Paulo, 2004.

[21] Centro de Ciências do Ambiente. Homepage: http://www.cca.ufam.edu.br/caema/dicas.html . Setembro, 2005

[22] Comgás. Homepage: http://www.comgas.com.br. Junho, 2005.

[23] Grupo de Estudos em Energia - Pontifícia Universidade Católica Minas Gerais 
Homepage: http://www.green.pucminas.br Junho, 2005.

[24] PROCEL - Programa Nacional de Conservação de Energia Elétrica Eletrobrás - Ministério de Minas e Energia. http://www.eletrobras.gov.br/procel/

[25] BEN - Balanço Energético Nacional Homepage: http://www.energiabrasil.gov.br/BEN/DadosEstaduais.asp. Setembro, 2005.

[26] Gestal - Gerenciamento de Energia Elétrica, Controlador de Demanda e Consumo. Homepage: http://www.gestal.com . Outubro, 2005.

[27] IWASHITA, J., SAIDEL, M.A. "Avanços e Barreiras para Implantação de Políticas de Conservação de Energia em Sistemas de lluminação. Estudo de Caso para Luminária de Aplicação Comercial". Artigo Técnico, X Congreso Brasileiro de Energia. Rio de Janeiro, 2004.

[28] BASTOS, MORET. H.S., SOUZA, A. "Substituição de Lâmpadas no Setor Residencial". Artigo Técnico, X Congreso Brasileiro de Energia. Rio de Janeiro, 2004.

[29] TOLMASQUIM, M.T, GARCIA A.G.P. "Eficiência Energética no Uso de Motores Elétricos. Artigo do IX CBE - Congresso Brasileiro de Energia. Rio de Janeiro, 2002.

[30] DE GROOTE, W., VERBRUGGEN, A. "Technologie voor Elektriciteitsbesparing in de Industrie". Antuérpia, Bélgica, 1992.

[31] MOREIRA, J.M. , SOUZA, J.G.M. " Conservação de Energia no Brasil" Instituto de Eletrotécnica e Energia - IEE /Universidade de São Paulo. 1998. 
[32] JANUZZI, G.M. “A Life-Cycle Cost Analysis (LCCA): Refrigerators in Brazil”. Energy Discussion Paper, 2003.

[33] Atlas Project - European Comission. "Adjustable Speed Drives". Homepage: http://europa.eu.int/comm/energy transport/atlas/htmlu/asdbib.html Agosto, 2005.

[34] TOLMASQUIM, M.T., SOARES, J.B. "Propostas de investimento do país em linhas de P\&D para a área de geração de energia elétrica" -Centro de Gestão e Estudos Estratégicos e COPPE/UFRJ. Rio de Janeiro, 2001.

[35] "Portal de Eletrônica” Homepage: www.eletronica.org . Novembro, 2005.

[36] JANUZZI, G.M. BAJAY, S.V., PACCOLA J.A. "A necessidade de revisão da atual estrutura de tarifas horosazonais para energia elétrica no País e de implantação de tarifas especiais para fornecimentos interruptíveis no período da ponta" IV Congresso ABAR (Associação Bras. das Agências de Regulação). Manaus 2005.

[37] ECKHOFF, S., OKOS M. "Solar Energy Heat Storage for Home, Farm and Small Business: Suggestions on Selecting and Using Thermal Storage Materials and Facilities". Department of Agricultural Engineering, Purdue University. EUA, 1995.

[38] JOCHEM, E. "Energy End-Use Efficiency - United Nations Development Programme". Homepage: http://www.undp.org. Outubro, 2005.

[39] UDAETA, M.E.M. et al “Novos Instrumentos de Planejamento Energético Regional Visando o Desenvolvimento Sustentável" Projeto de Pesquisa da Fundação de Amparo à Pesquisa do Estado de São Paulo. São Paulo, 2004. 
[40] Secretaria de Economia e Planejamento - Governo do Estado de São Paulo. "Região Administrativa de Araçatuba - Uma Proposta de Agenda para 2020”. São Paulo, 2000.

[41] OKOS, M., RAO, N., DRECHER, S., RODE, M., KOZAK, J. "Energy Usage in the Food Industry". Resumo Executivo. American Council for an Energy Efficient Economy, 1998. Homepage: http://www.aceee.org . Outubro, 2005.

[42] Industrial Technologies Program "Utica Corporation Plant-Wide Energy Assessment Report Final Summary" Energy Efficiency and Renewable Energy, U.S. Department of Energy Homepage: http://www.eere.energy.gov/industry/supporting industries/. Outubro, 2005.

[43] Rockwell Automation. Homepage: http://www.rockwellautomation.com Novembro, 2005.

[44] SEI-B -Stockholm Environment Institute - Boston Center, "LEAP2000.19" e "LEAP - Long-range Alternative Planning System. User Guide for Version 95.00. Data Checklist”. Tellus Institute, Boston - USA 2000.

[45] WITTE, L.C., SCHMIDT, P.S., BROWN, D.R. "Industrial Energy Management and Utilization”, Hemisphere Publishing Corporation. Texas, 1988.

[46] MOREIRA, E.M. “Modelo Energético para o Desenvolvimento Limpo Baseado na Filosofia do PIR - O Caso da Metrópole de São Paulo" Dissertação de Mestrado, Departamento de Energia e Automação da EPUSP. São Paulo, 2005. 
[47] Laboratório de Conforto Ambiental

Homepage: http://www.labcon.ufsc.br/projetos realizados.php . Junho, 2005.

[48] INO, W.T. "Primeira Projeção Multíplice do Planejamento Integrado de Recursos Energéticos Aplicado ao Médio Paranapanema". Projeto de Formatura. Departamento de energia e Automação da EPUSP. São Paulo, 2002.

[49] ESPINOLA, E.C.V. "Gerenciamento do Lado da Demanda em Sistemas de Distribuição de energia Elétrica". São Paulo, 2004. 56 p. Dissertação de Mestrado. Departamento de Energia e Automação da Escola Politécnica da Universidade de São Paulo.

[50] INHABER, H. "Why Energy Conservation Fails". Quorum Books, Londres, 1997.

[51] Northwest Power and Conservation Council - NWPCC - Homepage: http://www.nwcouncil.org/ . Junho, 2005.

[52] VERDE, V.S.V. "A Conservação de Energia Elétrica no Novo Modelo Institucional do Setor Elétrico Brasileiro", Tese de Mestrado da UFRJ, 2000.

[53] "A Eficiência Energética e o Novo Modelo do Setor Energético" Documento do Instituto Nacional de Eficiência Energética, INEE, 2001.

[54] International Energy Agency-IEA, Demand Side Management Programme. Homepage: http://dsm.iea.org/ . Maio, 2005.

[55] ANEEL - Agência Nacional de Energia Elétrica. Homepage: http://www.aneel.gov.br. Setembro, 2005. 
[56] MILANEZ, F.C."Para que conhecer o mercado consumidor de energia elétrica?" Rio de Janeiro. Portal GD, julho de 2004

[57] ADRADE, T.A. , LOBÃO, W.J.A. "Elasticidade Renda e Preço da Demanda Residencial no Brasil”, Texto para Discussão \#489, Rio de Janeiro, 97.

[58] LIMA, F.T.B.; LIMA, L.O. "Prospectiva Energética para o Desenvolvimento de São Paulo: Cenários 2020 e 2050" - Relatório Final do Projeto de Formatura 2001, PEA. EPUSP, São Paulo, 2001.

[59] SEADE. Fundação Sistema Estadual de Análise de Dados, http://www.seade.gov.br

[60] Secretaria de Energia e Meio Ambiente do Estado de São Paulo, Homepage http://www.energia.sp.gov.br . Abril, 2005.

[61] CETESB - Companhia de Tecnologia de Saneamento Ambiental, http://www.cetesb.sp.gov.br . Setembro, 2004.

[62] IBGE - Instituto Brasileiro de Geografia e Estatística. Homepage: http://www.ibge.gov.br . Outubro, 2005.

[63] JANUZZI, G. M.; SWISHER, J. N. P.; "Planejamento Integrado de Recursos Energéticos - Meio Ambiente, Conservação de Energia e Fontes Renováveis", Editora Autores Associados. Campinas, 1997.

[64] JANUZZI, G.M. "A conservação e o uso eficiente de energia no Brasil" Reportagem publicada na Com Ciência - Revista eletrônica de Jornalismo Científico.2004. http://www.comciencia.br/ 
[65] REDDY, B.S., PARIKH, J.K. "Economic and environmental impacts of demand side management programmes". Artigo Técnico. Indira Gandhi Institute of Development Research. India, 1997

[66] LEROY J. Pierre et. Ali. “Tudo ao Mesmo Tempo Agora - Desenvolvimento Sustentabilidade, Democracia: O que isso tem a ver com você" Editora Vozes, Petrópolis, Rio de Janeiro, 2002.

[67] UDAETA, M.E.M., BAITELO, R.L. “Aspectos Políticos do Gerenciamento do Lado da Demanda". CBR - Congresso Brasileiro de Regulação, Manaus, 2005.

[68] Centro de Pesquisas de Energia Elétrica. Homepage: http://www.cepel.br. Setembro, 2005.

[69] MARTINS, M.P.S. “Inovação Tecnológica e Eficiência Energética”. Monografia de Pós Graduação em Energia Elétrica, Instituto de Economia, Universidade Federal do Rio de Janeiro. Rio de Janeiro, 1999.

[70] BOARATI, J.H. “Avaliação Ponderada da Hidreletricidade e Termeletricidade através dos Custos Completos”. São Paulo, 2003. Dissertação de Mestrado. Departamento de Energia e Automação da Escola Politécnica da Universidade de São Paulo.

[71] CARVALHO, C.E. "Desenvolvimento de Procedimentos e Métodos para Mensuração e Incorporação das Externalidades em Projetos de Energia Elétrica: Uma Aplicação às Linhas de Transmissão Aéreas". São Paulo, 2005. Tese de Doutorado. Departamento de Energia e Automação da Escola Politécnica da Universidade de São Paulo. 
[72] AZEVEDO, F.M. "Análise Multidimensional do Modelo de Integração de Recursos Energéticos: Aplicação da Metodologia OLAP". São Paulo, 2005. Dissertação de Mestrado. Departamento de Energia e Automação da Escola Politécnica da Universidade de São Paulo. 